VERONICA FERREIRA BAHR CALAZANS

A filosofia da matemática nos Principia de Newton e suas implicações ontológicas

(VERSÃO CORRIGIDA)

Tese apresentada ao Programa de PósGraduação em Filosofia da FFLCH/USP, como exigência para obtenção do grau de Doutor em Filosofia, e realizada sob a orientação do Prof. Dr. Caetano Ernesto Plastino.

SÃO PAULO - 2014 
VERONICA FERREIRA BAHR CALAZANS

\title{
A filosofia da matemática nos Principia de Newton e suas implicações ontológicas
}

\author{
(VERSÃO CORRIGIDA)
}

Tese apresentada ao Programa de PósGraduação em Filosofia da FFLCH/USP, como exigência para obtenção do grau de Doutor em Filosofia, e realizada sob a orientação do Prof. Dr. Caetano Ernesto Plastino.
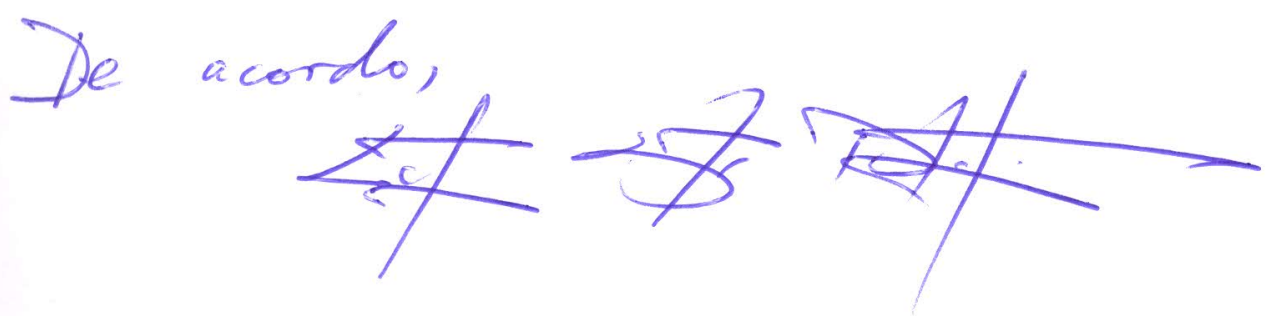

SÃO PAULO - 2014 
Aos meus filhos: Luiza e Arthur. 


\section{Agradecimentos}

Muitos foram os que contribuíram, das mais diversas formas, para a conclusão desse trabalho. A todos eles, minha gratidão. Primeiramente, agradeço ao Prof. Dr. Pablo Rúben Mariconda, que me recebeu no Programa e ao Prof. Dr. Caetano Ernesto Plastino, por aceitar a orientação dessa tese. Ao Prof. Dr. Osvaldo Frota Pessoa Junior, pela leitura atenta e generosa deste texto. À CNPq, pela concessão da bolsa de doutorado e à Capes pela concessão da bolsa de estágio no exterior. Ao Prof. Dr. Marco Panza e ao IHPST (Institut d'histoire et de philosophie des sciences et des techniques, CNRS/Université Paris 1 Panthéon - Sorbonne/ École normale), pela acolhida calorosa. À Isabelle Suzanne-M'Bengue e ao Djip pela grande hospitalidade. Ao Prof. Dr. Eduardo Salles de Oliveira Barra, que me apresentou aos estudos newtonianos e ao grupo da UFPR, coordenado por ele, que se dedica a esses estudos. Em especial, ao colega Luiz Felipe Sigwalt de Miranda pela grande generosidade. Ao Prof. Dr. Luiz Antonio Alves Eva, pelo impulso inicial. Finalmente, ao Alex, meu marido e eterno parceiro nos estudos, aos meus pais Mide e Werner e a todos os amigos e membros da minha família que acompanham cada passo desse processo. 


\title{
Resumo
}

O programa newtoniano de matematização da natureza fornece os elementos necessários para a investigação de uma filosofia da matemática no pensamento de Isaac Newton, especialmente ao se considerar a relação entre as práticas matemáticas de Newton e Descartes. Tal relação suscita uma gama bastante ampla de problemas os quais interessam para esta pesquisa, particularmente, aqueles que dizem respeito ao realismo matemático. O que pretendemos é extrair dessa discussão aspectos relevantes da filosofia e da prática matemática de Newton, com vistas a esclarecer em que medida suas opções matemáticas o comprometem com a ontologia dos objetos matemáticos.

\begin{abstract}
The Newtonian program of mathematization of nature provides the necessary elements for investigating the philosophy of mathematics in Isaac Newton's thought, especially when considering the relationship between the mathematical practices of Newton and Descartes. This relationship evokes a wide range of problems which are of interest for this research, in particular issues concerning mathematical realism. The goal is to extract from this discussion relevant aspects of the Newton's mathematical philosophy and practice, with a view to clarify how his mathematical options commit him to the ontology of mathematical objects.
\end{abstract}


SUMÁRIO

INTRODUÇÃO

1.OS ANTECEDENTES DA ANÁLISE NEWTONIANA.............................................

1.1 A análise cartesiana: a matemática como método nas Regulae ...............................20

1.2 Análise cartesiana: a matemática como disciplina na Geometrie.............................34

1.3 O Problema de Pappus: solução de Descartes..........................................................40

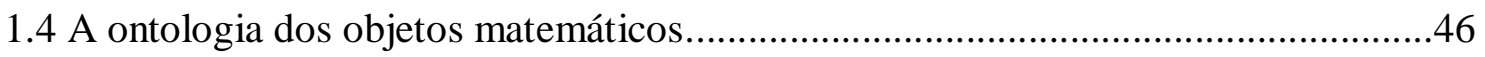

\section{A APRESENTAÇÃO ANALÍTICA DO MÉTODO DAS FLUXÕES DE}

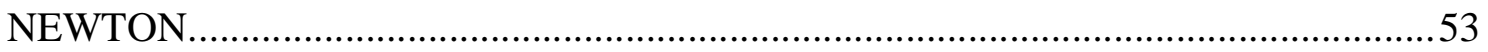

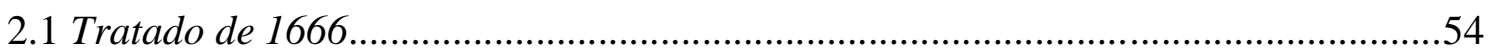

2.2 De Methodis: as operações fundamentais ...........................................................67

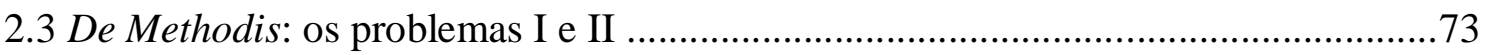

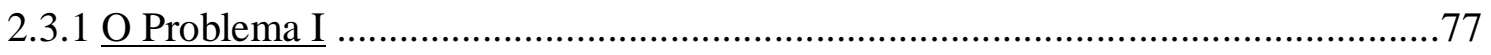

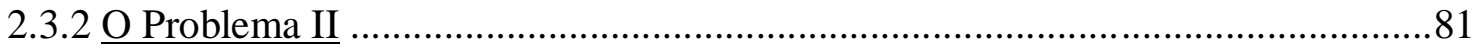

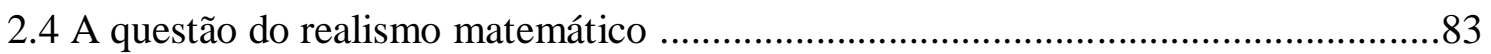

3 A CHAMADA “FASE SINTÉTICA” DA MATEMÁTICA NEWTONIANA ............87

3.1 O problema do estatuto do infinitamente pequeno ................................................90

$3.2 \mathrm{O}$ método das primeiras e últimas razões ..........................................................93

3.3 O retorno ao método sintético dos antigos e a solução de Newton para o problema

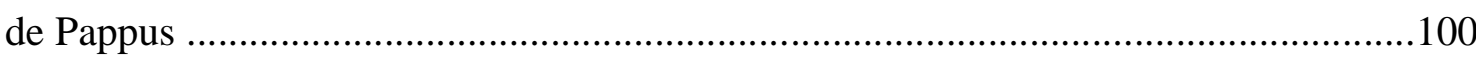


4 MATEMÁTICA E NATUREZA NOS PRINCIPIA .................................................... 114

4.1 O Livro I: determinação de forças centrípetas......................................................115

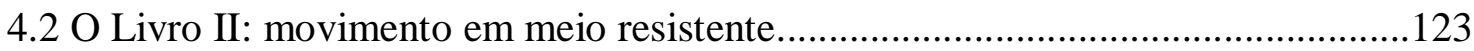

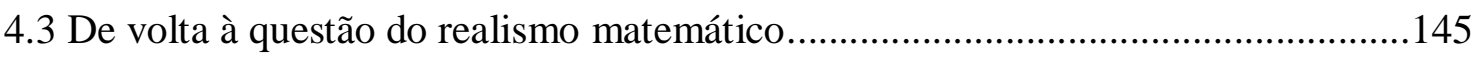

CONCLUSÃO

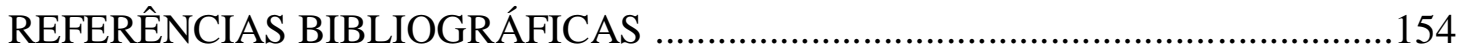




\section{INTRODUÇÃO}

O objetivo principal desta pesquisa é o de reconstruir aspectos da prática matemática de Isaac Newton a fim de investigar as implicações conceituais subjacentes às opções matemáticas. Em especial, as questões referentes ao realismo matemático newtoniano colocam-se como foco dos nossos esforços. Ou seja, pretendemos especular sobre o grau de comprometimento ontológico de Newton com relação aos objetos matemáticos. Na medida em que o próprio Newton omite seus pressupostos ontológicos na estrutura literária de seus textos, mas que, por outro lado, os torna acessíveis através de suas opções matemáticas, haverá imprecisões na caracterização de seu realismo matemático. Dito de outro modo, a pretensão de tratar do realismo matemático newtoniano deve contentar-se, inevitavelmente, com as comparações dos graus de comprometimento ontológico, sem que se possa definir ou descrever os fundamentos dessa ontologia.

Diante da vasta obra matemática newtoniana, espera-se que os Philosophiae Naturalis Principia Mathematica se ofereçam como campo privilegiado de investigação por serem a chamada obra da maturidade. Entretanto, as opções matemáticas expressas nessa obra são distintas daquelas da etapa inicial dos estudos newtonianos. Essa distinção evidencia de tal maneira as opções matemáticas do autor a ponto de que a tarefa de explicitar as possíveis articulações entre a etapa inicial e a etapa madura da matemática newtoniana é capaz de trazer à luz a discussão conceitual que não se encontra na superfície do texto de Newton.

A ampla utilização do método de análise cartesiano nos seus escritos matemáticos iniciais, por um lado, e a posterior crítica enfática a esse mesmo método, por outro, sugerem uma perspectiva para encarar todo o percurso da prática matemática de Newton, antes e depois dos Principia. Há duas abordagens distintas a esse respeito: 
uma destaca a ruptura e outra, a continuidade entre a etapa inicial da matemática newtoniana e a fase mais madura. Uma putativa crítica à análise de Descartes, como procurarei mostrar, parece se referir à falta de correspondência geométrica de alguns termos e símbolos empregados nas suas equações e técnicas algébricas, ou seja, o caráter não representativo de boa parte da análise cartesiana. A questão que se apresenta a partir daí é a de saber em que medida essa exigência de uma representatividade dos termos matemáticos persiste até os Principia. Assim, o que se pretende é esclarecer e aprofundar os tipos de articulações possíveis - ruptura, continuidade ou tanto uma quanto a outra - entre a prática matemática pregressa e a filosofia da matemática de Newton na época dos Principia e, desse modo, pôr em evidência as possíveis diferenças ontológicas subjacentes a cada uma dessas práticas.

As práticas matemáticas de Descartes e Newton têm implicações relevantes tanto metodológicas quanto ontológicas. Essas implicações, no entanto, tornam-se mais evidentes mediante um paralelo traçado entre tais práticas matemáticas. Isso, principalmente, devido ao papel que a crítica de Newton endereçada a Descartes exerce na fundamentação dos seus próprios conceitos matemáticos, físicos e, em última análise, ontológicos. Em linhas gerais, o que pretendo é investigar em que medida essa crítica a Descartes é determinante para a prática matemática de Newton e, consequentemente, para suas diversas implicações. Para tanto, considero como um passo preliminar a tarefa de analisar e distinguir as práticas matemáticas de Descartes e Newton, especialmente no que diz respeito às suas opções metodológicas pela análise e pela síntese, respectivamente.

Inicialmente, faz-se necessária uma remissão ao projeto cartesiano da mathesis universalis. As Regras para a Orientação do Espírito (1628) são consideradas o texto metodológico de Descartes por excelência. Essa ciência chamada de mathesis 
universalis é uma ciência geral, definida por seu método: investigar a ordem e a medida, sem que estejam aplicadas a alguma matéria especial. Tudo se resume em ordenar os objetos de investigação de modo a reduzir sua complexidade aos elementos mais simples e, em seguida, reconstituir essa complexidade de forma organizada a fim de torná-la compreensível. O método, descrito desse modo, mostra sua orientação declaradamente analítica. Embora o caráter universalista desse método caracterize-o pelo projeto de alcançar a todos os objetos dos quais o espírito possa ter um conhecimento "certo e indubitável", os objetos matemáticos apresentam-se como seus objetos privilegiados. Em virtude da simplicidade dos seus objetos, as matemáticas tornam-se o ponto de partida para a aplicação do método e, consequentemente, da extensão do domínio do conhecimento.

A possibilidade de uma "ciência universal" está, desse modo, inteiramente assentada em um requisito básico: a unidade do método. Esse, por sua vez, tem por fundamento último a unidade da própria razão. Ao inverter o referencial do conhecimento, que se desloca dos objetos desse conhecimento para a razão que os conhece, Descartes confere à razão a capacidade ilimitada de manipular todos os objetos. Se, do ponto de vista da razão, não há limites a serem estabelecidos, sobre o domínio dos objetos incide um critério segundo o qual nem todos os objetos se prestam ao conhecimento, apenas aqueles dos quais o espírito possa ter um conhecimento "certo e indubitável", como ensina a Regra II. Esse é, ao mesmo tempo, um critério ontológico, na medida em que não há sentido em considerar qualquer objeto que não se submeta à razão como objeto do conhecimento. Resta saber, pois, se diante da imposição desse novo critério o caráter representativo do conhecimento adquire um status secundário para Descartes. 
Segundo Marion (1975, p. 257), as Regulae retiram da coisa o seu fundamento próprio, construindo em seu lugar um objeto medido pela inteligibilidade, ou, da mesma forma, pela sua cognoscibilidade. Mas, ao mesmo tempo, elas formulam, ou pretendem fazê-lo, uma ontologia do objeto, uma ontologia, que é primeiramente negativa ao sujeitar o Ser ao entendimento. No entanto, a essa ontologia negativa se segue uma “recuperação dos 'lugares' da ontologia". A partir da mathesis universalis, o que fornece fundamento ao Ser não é mais seu caráter individual ou de espécie, mas o seu caráter relacional, visto que o ser do objeto é pensado como ordem e medida. O sujeito do conhecimento reconstrói o objeto por meio do ordenamento das relações que o consideram. O princípio desse objeto, então, é destituído da própria coisa e retido pelo sujeito que o reconstrói, ou seja, que o ordena, tornando-se seu fundamento último.

Tendo em vista o projeto de constituição da mathesis universalis, pode-se afirmar que não há a exigência de que o conhecimento da natureza, ou mesmo dos objetos matemáticos, possua um caráter estritamente representativo. O primeiro uso exemplar desse método encontra sua realização na obra La Géométrie de 1637: a mathesis universalis prepara o surgimento da geometria analítica, estabelecendo uma relação entre as operações da aritmética e as construções da geometria. Na Geometria, a teoria das proporções desempenha um papel fundamental. Ela é o meio pelo qual a ciência matemática pode tornar-se unificada, pois permite que seja dado à geometria um tratamento algébrico. O método apresentado nas Regulae consiste justamente em ordenar os objetos e estudá-los segundo a relação de proporção que eles mantêm entre si. Além disso, a Geometria nos oferece um modelo emblemático da opção cartesiana pelo método de análise. Os inegáveis resultados matemáticos promovidos por essa obra servirão de fundamento para a resolução de problemas em diversos autores posteriores a Descartes; Newton entre eles. 
Não há como negar a eficiência na resolução de problemas que o método cartesiano proporcionou para a matemática da modernidade. Newton, por exemplo, encontrou fundamento no método de Descartes para a solução de alguns dos problemas mais significativos do início dos seus trabalhos matemáticos. Porém, a partir de 1670, inicia-se um processo que chamaremos aqui de "virada metodológica". Newton passa a dirigir críticas relevantes ao método de análise cartesiano. Essas críticas vêm acompanhadas de um interesse pelos textos de geometria dos antigos, o que culmina com o abandono da análise e a adesão ao método sintético dos antigos. O ponto central da crítica a Descartes diz respeito à ausência de um correlato ontológico para os termos empregados nas equações, ou seja, à falta de correspondência geométrica desses termos: alguns elementos das equações não nomeiam genuinamente nenhuma entidade matemática canônica (geométrica ou numérica). A adesão de Newton ao método de síntese representa, por um lado, o abandono desses elementos desprovidos, segundo Newton, de caráter representativo; por outro, representa o abandono de um método cuja eficácia na solução dos problemas já havia sido demonstrada. Assim, embora Newton não trate propriamente de critérios ontológicos para os referentes matemáticos, a renúncia aos recursos matemáticos logrados pela análise em virtude da falta de correspondente geométrico dos seus elementos prenuncia um radical comprometimento com o realismo matemático.

Portanto, é necessário apresentar os elementos que apontam para o desenvolvimento da seguinte questão: de que maneira a "virada metodológica" é acompanhada, no projeto newtoniano, por uma "re-interpretação ontológica"? $\mathrm{Na}$ medida em que essa não é uma exigência para Descartes, a impossibilidade de garantir o correspondente ontológico dos objetos matemáticos não deve ser interpretada como inconsistência no interior do projeto cartesiano. Newton, por sua vez, acaba por atribuir 
a essa exigência o caráter de um postulado fundamental. Desse modo, a polêmica entre o que poderíamos chamar de um "formalismo abstrato" cartesiano e o "realismo matemático" newtoniano, revela que a diferença entre esses dois autores, para além de suas opções metodológicas distintas, alcança o nível de suas concepções ontológicas, e que essa diferença é a própria fonte de tal polêmica.

A leitura mais corrente sustenta que houve uma "virada metodológica" constituída por uma mudança radical na orientação das concepções matemáticas de Newton. Ou seja, os resultados alcançados por Newton, utilizando-se da análise cartesiana, estavam consubstanciados no cálculo das fluxões, que Newton desenvolveu entre os anos 1664 e 1669, sob forte inspiração da Geometria de Descartes. Entretanto, no início da década de 1670, Newton teria regressado a uma concepção geométrica mais clássica na qual a linguagem analítica perde seu papel central num movimento de "retorno à geometria dos antigos". Em linhas gerais, essa leitura sustenta que houve uma ruptura do ponto de vista da orientação matemática na passagem para a etapa mais madura da obra de Newton. Essa tese representa a abordagem da maioria dos comentadores que se dedicaram a questões dessa natureza, tais como Arthur, De Gandt e Cajori, com especial destaque para Nicolò Guicciardini. A prática matemática de Newton estaria, portanto, claramente dividida em dois períodos: o primeiro em que Newton desenvolve a nova análise cartesiana (e wallisiana) e que tem seu auge no De Methodis (escrito por volta de 1669 e publicado, postumamente, em 1736); e o segundo, um período sintético que culmina com os Principia em que o formalismo algébrico dá lugar à geometria, os infinitésimos são substituídos pelos limites e o método analítico dos modernos perde seu espaço para o método sintético dos antigos, cf. Guicciardini (2004) p.467. Mesmo que haja um consenso em admitir alguma diferença na abordagem entre o Newton jovem e o maduro, ainda restaria a questão de saber se essa divergência 
constitui propriamente uma ruptura. Se constituir, podem-se delimitar claramente dois períodos distintos e o problema a ser considerado será o de identificar a razão dessa ruptura. Nesse sentido, o comprometimento de Newton com o realismo matemático se oferece como um elemento essencial da resposta. Isso porque, partindo dessa leitura, pode-se concluir que o abandono da análise deve-se, entre outros elementos, ao caráter não representativo de certos símbolos utilizados nos procedimentos analíticos, como no exemplo da solução do problema de Pappus, cuja reformulação, exposta por Newton, elimina esses símbolos que não representam nenhum objeto propriamente matemático.

Desse modo, a suposição de que a ruptura não é a única articulação possível entre a fase inicial e a fase madura da obra matemática newtoniana não tem o papel de, simplesmente, substituir uma leitura majoritariamente aceita. Ao contrário, ela pretende ampliar os contornos de uma discussão que não se esgota em uma ou outra abordagem. Se, por um lado, a tese da ruptura parece destacar as opções metodológicas completamente diferentes, separando uma fase analítica e outra sintética na matemática de Newton; por outro, a abordagem continuísta destaca as similaridades entre essas fases supostamente distintas. Tais similaridades dizem respeito, principalmente, aos problemas e aos objetos matemáticos que se manteriam os mesmos. Então, o propósito desse texto não é o de decidir por uma das duas abordagens, mas o de argumentar em favor de que um tratamento adequado às questões relativas ao retorno de Newton à geometria dos antigos não pode negligenciar a "virada metodológica" sustentada pela tese da ruptura; mas, igualmente, não pode ignorar as similaridades destacadas pela tese da continuidade.

Com a finalidade de delimitar um percurso que contemple satisfatoriamente as nuances dessa questão cuja amplitude é constitutiva, esta tese está dividida em quatro capítulos. O primeiro deles trata da análise cartesiana, visto que esta é uma fonte das 
mais importantes nos estudos iniciais de Newton. Além da inegável importância da herança matemática e do diálogo que Newton estabelece, nem sempre de forma explícita, com Descartes, o tratamento dado por Descartes aos objetos do conhecimento ou, em outras palavras, a ontologia cartesiana dos objetos, especialmente matemáticos, serve de parâmetro para a discussão da ontologia dos objetos matemáticos newtonianos. Tal parâmetro constitui uma mediação privilegiada, entre as inúmeras possíveis, na tentativa de tratar de questões que não são diretamente consideradas na obra de Newton.

O segundo capítulo contempla a fase inicial da matemática newtoniana. Pretende-se, primeiramente, esclarecer em que sentido atribui-se a essa fase o adjetivo de analítica. Em seguida, a questão que se põe é a de saber em que medida pode-se garantir a unidade metodológica da fase inicial da matemática de Newton, caracterizando-a como um bloco homogêneo. A geometria algébrica introduzida por Descartes na Geometria consiste em certos procedimentos argumentativos capazes de associar, a uma ampla classe de curvas, equações algébricas que as definem. Tais procedimentos são estendidos e enriquecidos por Newton, nessa etapa inicial de sua matemática, alcançando algoritmos mais gerais. Entretanto, o Tratado de Outubro de 1666 mostra, pelas diferentes abordagens na solução de problemas semelhantes, que a pretensa unidade metodológica da primeira etapa dos estudos matemáticos newtonianos está longe de ser trivial. A escolha do segundo texto, a ser analisado nesse capítulo, está isenta de justificativas, visto que ele concentra a apresentação analítica do método das fluxões. Trata-se do De Methodis Serierum et Fluxionum. O desenvolvimento dos dois problemas iniciais dessa obra fornecerá o conteúdo que servirá de parâmetro a ser comparado com a chamada fase sintética da matemática newtoniana.

O capítulo 3 concentra o foco principal da pesquisa: a matemática dos Principia. Primeiramente, considera a transição do método das fluxões, em sua apresentação 
analítica, para a apresentação sintética desse método, chamada por Newton de método das primeiras e últimas razões. Essa transição se dá em um contexto em que o formalismo algébrico dá lugar à geometria, os infinitésimos são substituídos pelos limites e o método analítico dos modernos perde seu espaço para o método sintético dos antigos. Em seguida, analisa as implicações conceituais de tal transição, especialmente no que diz respeito às exigências ontológicas explicitadas pelas "novas opções metodológicas".

Por fim, assim como nos perguntamos pela unidade metodológica da etapa analítica, estendemos a pesquisa a um segundo momento dos Principia em que o que está em jogo não é mais o método das primeiras e últimas razões, mas a consideração matemática de grandezas pertencentes à natureza e a demonstração das leis que regem as relações entre tais grandezas. Novamente, embora estejamos no escopo da chamada etapa sintética da matemática newtoniana, a tentativa de afirmar a homogeneidade desse bloco não apresenta menos problemas do que aqueles advindos da tarefa análoga, imposta à etapa analítica. É justamente a complexidade encontrada nessas articulações que fornecerá os contornos a partir dos quais pode-se tratar de uma filosofia da matemática newtoniana. 


\section{OS ANTECEDENTES DA ANÁLISE NEWTONIANA}

Afirmar que a etapa inicial da obra matemática newtoniana caracteriza-se principalmente por certa unidade metodológica, residente na escolha pelo método de análise, requer alguns esclarecimentos. Primeiramente, é preciso localizar historicamente o que se entende por análise neste caso, visto que esse mesmo termo nomeou procedimentos matemáticos distintos ao longo do tempo. Nesse processo é inevitável a remissão a Descartes, pois esta parece ser a fonte mais representativa e influente daquilo que Newton nomeia como a "nova análise" em sua obra.

Panza (2010) destaca três sentidos que o termo "análise" assumiu ao longo da história da matemática, sem, contudo, pretender esgotar os possíveis significados para esse termo, segundo ele, altamente polissêmico. O primeiro deles é a "análise aristotélica", entendida como um padrão de argumentação amplamente - porém, não exclusivamente - utilizado pelos matemáticos gregos antigos, árabes e primeiros modernos. Na maioria dos casos, o termo está inserido no contexto do "método de análise e síntese" e se baseia na consideração de algo, que ainda não está disponível, como se já estivesse disponível. O segundo sentido se refere à "análise vieteana", caracterizada pelo uso das equações a partir de certas regras que regem tal formalismo. Por fim, Panza destaca a "análise euleriana". Somente ela pode ser compreendida como uma teoria matemática autônoma. Essa teoria matemática teria parte de sua gênese na introdução por Newton do termo 'fluxão' em sua fase analítica. Entretanto, não se pode considerar que esta fase analítica de Newton seja, ela própria, uma teoria matemática independente. Assim, a questão de saber em que sentido a fase inicial dos estudos matemáticos de Newton é analítica tem sua resposta no primeiro sentido do termo "análise", no segundo sentido ou em ambos. 
A chamada "análise aristotélica" foi utilizada desde a antiguidade pelos matemáticos gregos. Historicamente, foi nomeada como "análise problemática" quando aplicada à resolução de problemas geométricos; e como "análise teoremática" quando seu objetivo final é a demonstração de teoremas. Para as finalidades dessa pesquisa, interessa-nos especialmente a primeira; entretanto, o que se diz dela pode facilmente ser aplicado à análise teoremática (e vice-versa), realizando-se as devidas adaptações. Em ambos os casos, a descrição corrente desse procedimento analítico identifica como sua principal característica o "caminho inverso" percorrido por ele. Ou seja, parte-se do que é pedido no problema e chega-se a algo dado. A síntese, ao contrário, realiza uma prova que parte dos dados e alcança o que é pedido. Embora ainda superficial, tal descrição constitui uma aproximação bastante verossímil. Porém, é preciso esclarecer de que modo esse "caminho inverso" é percorrido, ou perguntar se realmente trata-se do mesmo caminho percorrido pela síntese, apenas tendo a ordem de seus passos invertida.

A síntese, como procedimento de prova, utiliza a dedução para percorrer o caminho entre o que é dado e o que é pedido. Se considerássemos que a análise faz o caminho inverso, nos depararíamos imediatamente com um problema lógico. Para garantir a legitimidade dessa inversão, ou seja, para garantir que a análise também fosse um procedimento dedutivo, todas as implicações (tomadas no sentido operado pela síntese) deveriam se transformar em equivalências. Portanto, a afirmação de que a análise percorre o caminho inverso da síntese não deve ser entendida em um sentido lógico. Isso porque, diferentemente da síntese que, como dito acima, é um procedimento de prova, a análise é um procedimento de descoberta ${ }^{1}$. Ela não percorre (e não precisa percorrer) um caminho linear dedutivo do requerido no problema aos dados. Apenas, trata ambos como dados envolvidos na solução do problema, com o propósito de

\footnotetext{
${ }^{1}$ A análise é um procedimento de descoberta não do que é pedido no problema. O que ela descobre são os passos necessários para a resolução do problema.
} 
determinar o que é pedido pelo que é dado, ou, extrapolando um pouco, estabelecer a relação entre eles.

Assim, a análise é, de certo modo, hipotética. Por essa razão, ela precisa ser complementada pela etapa sintética do método. ${ }^{2}$ Seu primeiro passo - o famoso ato de supor o problema resolvido - supõe que todos os elementos necessários para a solução do problema já estão presentes, ao menos potencialmente, no momento em que trata como dados do problema tanto os elementos conhecidos quanto os pedidos. Porém, pode ser necessário introduzir elementos auxiliares a fim de completar a cadeia de dependências que deve ser estabelecida para a solução do problema. Esses passos intermediários não têm nenhuma sustentação lógica ou mesmo algorítmica que lhe garantam o êxito. Aí reside o caráter hipotético da etapa analítica do método. Tal instabilidade é própria de um processo que se caracteriza como descoberta e não como prova na solução do problema. O êxito na escolha deste ou daquele passo intermediário somente será chancelado pela etapa sintética.

O segundo sentido para o termo análise, destacado por Panza, é a "análise vieteana". Ela é caracterizada pelo formalismo e suas regras na manipulação dos símbolos que possibilitam a obtenção de equações. Porém, não se trata de outro método, distinto do "método de análise e síntese" aplicado à geometria. Trata-se, isto sim, de técnicas particulares desenvolvidas no interior do método. Isso se torna mais evidente ao considerarmos o próprio conceito de equação: nada mais do que a expressão da relação entre o que é dado e o que é pedido, ou o que se pretende determinar. Ao igualar os dois lados de uma equação, dá-se o primeiro passo da análise, ou seja, considera-se o problema como resolvido a fim de encontrar o elemento não conhecido através do elemento dado. O elemento não conhecido, ou seja, o elemento pedido no problema é

\footnotetext{
${ }^{2}$ Se a análise pudesse proceder a uma dedução às avessas, não seria necessário complementá-la com a síntese, pois sua validade lógica estaria assegurada. Efetivamente, isso pode ocorrer em algumas demonstrações matemáticas em que os elementos da prova estão ligados por bi-implicações.
} 
representado por uma incógnita e posto em relação com os demais elementos, na equação. Então, assim como na análise geométrica, a solução do problema consiste na manipulação das relações entre os dados e o que é requerido. No entanto, a novidade que faz com que Panza distinga a "análise vieteana" da "análise aristotélica" reside justamente no formalismo. Viète diferencia números de espécies (species) (cf. Viète, p. 17), caracterizando-as como símbolos ou signos dos objetos matemáticos. Isso significa que essas espécies podem representar outros gêneros de objetos matemáticos que não sejam numéricos, por exemplo, objetos geométricos. As regras que regem esse simbolismo evocam vários sentidos distintos para o termo "análise" (distinção estabelecida pelo próprio Viète) que, no entanto, são complementares e de modo algum opostos entre si. Do mesmo modo, em nada ampliam o método da análise aristotélica, mas ampliam, isto sim, sua generalidade. Ao afirmar que não opera mais com os números e sim com as espécies, Viète inaugura a possibilidade de um único método ser aplicado a objetos matemáticos diferentes (aritméticos e geométricos, por exemplo) ${ }^{3}$.

Portanto, a distinção entre "análise aristotélica" e "análise vieteana" somente se justifica se o objetivo for destacar o formalismo acrescentado por essa última, visto que elas compartilham um mesmo método. Assim, a questão de saber em que sentido atribuímos a Descartes (e, consequentemente a Newton) a característica de um procedimento matemático analítico será respondida no âmbito desses dois modos de se conceber a análise. É preciso explorar as soluções dos problemas desenvolvidas por eles para, por um lado, perguntar se o método utilizado corresponde ao método da "análise aristotélica" (também utilizado por Viète), e, por outro, perguntar de que modo o formalismo característico da "análise vieteana" é introduzido em tais soluções.

\footnotetext{
${ }^{3}$ Embora tal êxito seja atribuído a Viète, ele não deixa de ser igualmente alcançado por Kwarizmi, matemático árabe do século IX (cf. Panza, 2008).
} 


\subsection{A análise cartesiana: a matemática como método nas Regulae}

Descrever o papel da matemática no pensamento cartesiano é uma tarefa que possui, inegavelmente, duas vias. A consagrada afirmação de que a matemática se oferece como modelo metodológico para as demais disciplinas do conhecimento humano não exclui a necessidade de que, ela própria, seja considerada uma entre essas disciplinas. Nesse contexto, o conceito de mathesis universalis desempenha um papel fundamental. Definida como a "ciência geral que explica tudo quanto se pode procurar referente à ordem e à medida, sem as aplicar a uma matéria especial" (Descartes. 1999.[1628], p. 27), ela é caracterizada como uma ciência das relações quantitativas sem que seja aplicada a este ou aquele objeto especificamente, como ocorre nas ciências das quantidades particulares. Ou seja, ela distingue-se do que Descartes chama de matemáticas comuns por ser a fonte de todas as ciências matemáticas e, por isso, ser anterior e mais fundamental em relação às demais. Ao expor essa relação entre a mathesis universalis e as matemáticas comuns, pretendo tornar mais compreensível em que sentido a matemática se oferece como modelo metodológico para as demais ciências e, por outro lado, como ela própria se caracteriza como disciplina.

As Regras para a Orientação do Espírito (1628) concentram o que se pode chamar de uma "teoria do método", cujo objetivo é exposto logo na primeira regra: "Os estudos devem ter por meta dar ao espírito uma direção que lhe permita formular juízos sólidos e verdadeiros sobre tudo que se lhe apresenta" (Descartes, 1999, p. 1). Desse modo, o método é a direção que possibilita à razão atingir sua pretensão. Essa direção é una como a própria razão; enquanto que os objetos que se apresentam a ela guardam sua multiplicidade. Segundo Descartes, os homens fazem uma aproximação errônea entre as ciências (que dependem apenas de conhecimento intelectual) e as artes (que exigem 
algum esforço do corpo). No caso das últimas, é preferível dedicar-se a uma delas de cada vez, pois o desenvolvimento de uma segunda arte pode implicar a necessidade de habilidades que atrapalhem a primeira. Seguindo o exemplo do texto, o cultivo da terra e o aprendizado da cítara exigem habilidades manuais incompatíveis. Entretanto, não é este o caso das ciências. Já que todas elas fazem parte da sabedoria humana, o estudo de uma contribui para o aprendizado das outras, não obstante a multiplicidade dos seus objetos. Descartes apresenta assim seu argumento: se todas as ciências nada mais são do que sabedoria humana; se a sabedoria humana permanece uma e a mesma, seja qual for a diferença dos assuntos aos quais ela é aplicada; e, se ela não confere mais distinções aos assuntos aos quais ela é aplicada do que a luz do sol confere às coisas que ilumina; então, "não é necessário impor ao espírito nenhum limite" (Descartes, 1999, p. 2) . Com isso, ficam estabelecidos dois elementos básicos necessariamente interligados: a unidade da razão e sua ausência de limites. Pelo que foi dito, a fim de procurar seriamente a verdade, não se deve escolher uma ciência em particular; todas elas estão ligadas e dependem umas das outras. Assim, a possibilidade de se estabelecer um método único aplicável a todas as ciências constitui o fruto metodológico mais importante desse percurso.

Entretanto, se a razão, como apresentada nas Regulae, é desprovida de limites, os objetos do conhecimento, por outro lado, devem ter seu escopo cuidadosamente delimitado, o que Descartes faz através da definição de ciência. Na Regra II, a ciência é definida como "um conhecimento certo e evidente" (Descartes, 1999, p. 5). Essa definição limita o domínio dos objetos a serem tomados na investigação da verdade; eles devem ser apenas "aqueles que os nossos espíritos parecem ser suficientes para conhecer de uma maneira certa e indubitável” (idem). Então, a razão ilumina seus 
objetos segundo critérios que ela própria estabelece, dos quais o primeiro é justamente este: desprezar os objetos que não podem ser conhecidos com clareza e distinção ${ }^{4}$.

É exatamente no que se refere à clareza e distinção que a matemática se coloca à frente como exemplo de conhecimento certo e seguro. "A aritmética e a geometria são as únicas [disciplinas conhecidas] isentas de qualquer defeito de falsidade ou de incerteza" (Descartes, 1999, p. 8), ou seja, são as únicas que cumprem o requisito aqui estabelecido. Nas demais ciências, por outro lado, vê-se que seus estudiosos não conseguem entrar em acordo mesmo quando se trata de questões corriqueiras. O motivo para isso está nos objetos das matemáticas; eles são puros e simples, isto é, dispensam suposições da experiência sendo, então, suas consequências deduzidas racionalmente. Isso não quer dizer que a razão não possa atingir os objetos cujo conhecimento depende da via da experiência, mas que, mesmo nesse caso, "não se deve ocupar-se com nenhum objeto sobre o qual não se possa ter uma certeza tão grande quanto aquela das demonstrações da aritmética e da geometria” (Descartes, 1999, p. 10). Assim, essa regra confere ao método a possibilidade de se ampliar o domínio do conhecimento para além das disciplinas matemáticas, contanto que se respeite o critério exposto pela regra. Em outras palavras, para lograr esse êxito, o método deve excluir do campo da ciência aquilo que é apenas provável e o que não é certo e evidente.

Além disso, é preciso traçar a diferença entre aprender a história de uma ciência e aprender a própria ciência. Segundo Descartes, há vantagens em se dedicar à leitura das obras dos antigos, pois nelas se podem conhecer as invenções já feitas com sucesso e descobrir o que ainda falta para ser encontrado nas disciplinas. Entretanto, pode-se contrair o que ele chama de "manchas de erro". Os escritores utilizam argumentos para atrair seus leitores e fazê-los acreditar naquilo que eles mesmos acreditam sem que

\footnotetext{
${ }^{4}$ Esse é um tema tratado à exaustão pelos comentadores das Regulae: a inversão do foco do conhecimento. O foco deixa de ser a multiplicidade dos objetos a serem conhecidos e converte-se na razão una que os conhece. Para mais detalhes ver Marion (1997 [1975]).
} 
tenham passado por uma reflexão consistente. Mesmo quando mostram algo que é certo e evidente, fazem-no em meio a rodeios desnecessários. Adquirir o ensinamento dessa forma (por meio das obras dos antigos), ainda que estivesse correto, não é adquirir ciência, mas apenas história.

Então, prossegue Descartes, se queremos fazer algum juízo sobre a verdade das coisas, não devemos mesclar absolutamente nenhuma conjectura. Há somente dois atos do entendimento que nos permitem alcançar o conhecimento das coisas sem engano: a intuição e a dedução. Esta última é definida como "toda conclusão necessária tirada de outras coisas conhecidas com certeza" (Descartes, 1999, p. 15). Todavia, cabe ainda expor o que Descartes entende por intuição:

Por intuição entendo não a confiança instável dada pelos sentidos ou o juízo enganador de uma imaginação com más construções, mas o conceito que a inteligência pura e atenta forma, sem dúvida possível, conceito que nasce apenas da luz da razão e cuja certeza é maior, por causa de sua maior simplicidade, do que a da própria dedução (...) (Descartes, 1999, p. 13-14).

A intuição é, portanto, uma evidência atual que fornece os primeiros princípios numa cadeia de conhecimento. As conclusões que são retiradas desses princípios são fruto de um movimento, de uma sucessão: a dedução. O método, entendido assim, não é uma composição dessas duas operações intelectuais. Visto que elas são as primeiras e mais simples operações, elas precedem o método, pois nem os preceitos desse método poderiam ser compreendidos sem que o entendimento fizesse uso delas. O papel do método é fornecer as regras de utilização dessas operações. Se a intuição e a dedução forem executadas corretamente, produzirão exclusivamente aquele "conhecimento certo e indubitável" requerido na Regra II. Isso quer dizer que, ao definir a intuição e a dedução como as operações do conhecimento, Descartes está redefinindo o domínio do conhecimento não mais do ponto de vista dos objetos, mas do ponto de vista do sujeito. 
Finalmente, a Regra IV encerra esse conjunto de regras preliminares, afirmando a necessidade do método: "O método é necessário para a busca da verdade" (Descartes, 1999, p. 11). Descartes afirma que a maior parte dos estudiosos, nas mais diversas áreas, procura a verdade às cegas, de modo aleatório, como quem quer encontrar um tesouro e vagueia sem rumo procurando. Às vezes alguns deles têm sucesso, não por possuírem uma habilidade especial, mas por pura sorte. Assim agindo, eles obscurecem a luz da razão, pois se acostumam a estudar sem ordem e produzir "meditações confusas". Por isso, seria preferível não buscar o conhecimento a buscá-lo sem método.

Porém, até esse ponto, Descartes não apresentou nenhuma definição do que seja esse método cuja importância e necessidade são tão categoricamente afirmadas. É o que ele faz a seguir, caracterizando o método como um conjunto de regras que devem ser certas e fáceis. Qualquer um que observe essas regras com exatidão deve ser capaz de colher dois proveitos: jamais tomar algo que é falso por verdadeiro e alcançar o "verdadeiro conhecimento de tudo quanto for capaz de conhecer" através de um processo gradual e contínuo e sem "despender inutilmente nenhum esforço de inteligência" (Descartes, 1999, p. 20). A primeira parte (não tomar o falso por verdadeiro) é garantida pela intuição e a segunda (alcançar o conhecimento verdadeiro de tudo) pela dedução.

Tendo definido o que ele entende por método, Descartes passa a considerar os antecedentes históricos desse método. Tais antecedentes, porém, não devem ser tomados como um reconhecimento de que outros, antes dele, tivessem desenvolvido os princípios de um método que Descartes levou a termo. Muito longe disso, Descartes toma para si a autoria do método e afirma que, durante a história que o precedeu, alguns perceberam a utilidade desse método como um fruto espontâneo da inteligência humana: "Isso porque a inteligência humana tem não sei quê de divino, onde as 
primeiras sementes de pensamentos úteis foram lançadas de tal modo que, em geral, por mais desprezadas e por mais sufocadas que sejam por estudos mal feitos, produzem um fruto espontâneo" (Descartes, 1999, p. 21).

O exemplo que Descartes utiliza para apoiar sua tese é de suma importância para a compreensão dos fundamentos matemáticos desse método, pois é retirado das "mais fáceis das ciências, a aritmética e a geometria" (Descartes, 1999, p. 21). Os geômetras antigos dominavam uma "espécie de análise" que podia ser estendida à solução de todos os problemas. Entretanto, não deixaram que a posteridade a ela tivesse acesso. $\mathrm{O}$ procedimento analítico dos antigos figura, então, entre aquelas "primeiras sementes de pensamentos úteis" que foram sufocadas. Outro exemplo, este mais recente, é a álgebra, que permite que "se faça com os números o que os antigos faziam com as figuras". Os dois exemplos são retirados das matemáticas pois, sendo seus objetos mais simples, seus estudiosos teriam alcançado maior êxito. O propósito de Descartes, no entanto, que começa a tomar forma no texto, é o de dar consistência a estas conquistas e estendê-las a assuntos mais complexos:

(...) e não me espanto que seja nessas artes, cujos objetos são muito simples, que eles cresceram até agora com mais felicidade do que nas outras, em que maiores obstáculos comumente os sufocam, mas em que, não obstante, tomando um cuidado extremo em cultivá-los, nós os faremos infalivelmente alcançar uma perfeita maturidade (Descartes, 1999, p. 22).

Alcançar a maturidade no que diz respeito àquelas ciências cujos objetos são mais complexos que os objetos matemáticos é, de certo modo, o projeto das Regulae. A aritmética e a geometria servem de modelo para essa empreita que poderia ser resumida na tarefa de conferir inteligibilidade e revelar o significado epistemológico daquelas conquistas alcançadas pelas matemáticas e estendê-las às demais ciências. É preciso ainda discutir de que modo as matemáticas devem exercer esse papel de padrão epistêmico para as demais e, como consequência disso, expor as razões da opção de Descartes pelo método de análise, em detrimento do método sintético. 
A Regra II afirma que a Aritmética e a Geometria são as únicas disciplinas isentas de qualquer defeito de falsidade ou de incerteza. Essa afirmação pode parecer, a uma primeira leitura, a corroboração da tese, anunciada acima, de que a matemática fornece o modelo metodológico para as ciências. De certa forma é assim, mas são necessárias algumas distinções. Descartes opta por admitir entre os objetos da ciência apenas aqueles que possam ser conhecidos de modo certo e indubitável. O objeto da matemática cumpre esse requisito por ser tão puro e simples a ponto de dispensar as suposições cuja certeza é abalada pela experiência. Por isso, não há como se enganar na Aritmética e na Geometria: elas são inteiramente compostas de consequências deduzidas racionalmente, sem qualquer interferência da experiência. Assim, se o objeto de uma pretensa ciência não fornece a possibilidade de uma certeza tão grande quanto a daqueles cujas propriedades e relações são suscetíveis de demonstrações matemáticas, não se deve ocupar-se dele.

Entretanto, adiante Descartes observa:

Alguns deles (mortais possuídos por uma curiosidade cega) são como um homem que arderia de um desejo tão estúpido de encontrar um tesouro que ficaria incessantemente vagueando por praças públicas para procurar se, por acaso, não encontrasse algum perdido por um viajante. É assim que estudam quase todos os Químicos, a maior parte dos Geômetras e grande número dos filósofos (Descartes, 1999, p. 19).

Como pode que o geômetra, dedicando-se a uma ciência cujo objeto possibilita tamanha clareza, vagueie sem método em seus estudos? É possível porque, embora a Aritmética e a Geometria sejam modelos de certeza, nem sempre a clareza e a exatidão de uma demonstração trazem consigo um bom método. Descartes desvincula esses dois aspectos.

Portanto, não será qualquer uso das matemáticas que poderá servir como instância exemplar do padrão metodológico visado por Descartes, ainda que todos os 
casos sejam igualmente isentos da falsidade e da incerteza. É preciso considerar, aqui, a distinção entre as matemáticas comuns e a verdadeira matemática, chamada de mathesis universalis. Ela fica ainda mais clara na afirmação de que as Regras não têm como propósito "resolver os vãos problemas que servem normalmente de jogo para os Calculadores ou para os Geômetras em seus lazeres" (Descartes, 1999, p. 22). O que se diz dos problemas é que eles são vãos; não se põe em cheque a certeza dos seus resultados ou a clareza dos seus objetos. Descartes, em seguida, acrescenta que tratará de figuras e números "porque não se pode pedir a nenhuma das outras disciplinas exemplos tão evidentes e tão certos" (Descartes, 1999, p. 22). Ainda assim, tudo isso se refere às matemáticas comuns. Elas são as vestes, e não as partes, da mathesis universalis. As matemáticas comuns são as vestes porque seus objetos são simples e fazem com que a mathesis universalis apresente-se de modo mais adaptado ao espírito humano. Porém, elas não podem ser partes dessa disciplina porque deixaram que se perdesse justamente o procedimento que faz da mathesis universalis o modelo metodológico: a análise. "Essa disciplina deve, de fato, conter os primeiros rudimentos da razão humana e estender sua ação até fazer jorrar as verdades de qualquer assunto que seja" (Descartes, 1999, p. 23). Estender sua ação é o mesmo que emprestar o método. Ela é a fonte das demais disciplinas, na medida em que, nela, todas encontram o modelo segundo o qual devem proceder.

Quanto às matemáticas comuns, visto que são as "mais fáceis das ciências", sua história mostra que alguns antigos já haviam percebido a utilidade desse método, o que se deixa transparecer na espécie de análise que os geômetras utilizaram, de modo a estendê-la à solução de todos os problemas. Todavia, segundo Descartes, essa análise não foi preservada. Por outro lado, embora as matemáticas comuns estejam plenas de sequências que evidenciam consequências rigorosas, a demonstração da solução de um 
problema, por mais certeza que carregue, não mostra, necessariamente, porque é assim e como se chega a ela. $\mathrm{O}$ estudo dessas disciplinas, feito desse modo, é fútil, pois não ensina o entendimento a resolver outros problemas e, em alguma medida, faz com que se perca o hábito de utilizar a razão. A mathesis universalis é analítica - condição para que possa servir como modelo metodológico. Já as matemáticas comuns, embora sejam exemplos de verdade e clareza, são incapazes de converterem-se em qualquer tipo de orientação metodológica, visto que são sintéticas, isto é, por limitarem-se às demonstrações ou provas das descobertas feitas anteriormente na análise.

Descartes reconhece, não propriamente as fontes, mas traços da mathesis universalis, ou melhor, do método que a define, entre os antigos geômetras gregos ou inseridos na tradição dos gregos.

E, por certo, parece-me que alguns traços dessa verdadeira matemática ainda aparecem em Pappus e em Diofanto, que, sem serem dos primeiros anos, viveram, porém, numerosos séculos antes do nosso tempo. Quanto a ela, eu acreditaria de bom grado que, mais tarde, os próprios autores a fizeram desaparecer com uma espécie de ardil censurável. (...) e preferiram, para fazerse admirar, apresentar-nos, em seu lugar, algumas verdades estéreis demonstradas com um sutil rigor lógico como efeitos de sua arte (...) Houve, por fim, alguns homens muito engenhosos que se esforçaram em nosso século para ressuscitar a mesma arte, pois aquela que é designada pelo nome bárbaro de álgebra não parece ser outra coisa (...) (Descartes, 1999, p. 26)

Em linhas gerais, diz-se que a análise distingue-se por ser um método que procede "de trás para frente" ou "contra a corrente", pois parte da solução do problema, considerado inicialmente como resolvido, para chegar ao que já era conhecido (ver introdução a este capítulo). Geralmente, a análise vem acompanhada de uma etapa complementar: a síntese, que faz o caminho inverso, ou seja, é posterior à etapa inventivo-resolutiva (análise). A síntese é, portanto, um procedimento de prova - que serve para mostrar que o elemento encontrado pela análise efetivamente soluciona o problema - e não um procedimento propriamente de descoberta. 
Entre os geômetras antigos, o procedimento de análise era amplamente utilizado como uma das etapas da resolução de problemas de ordem geométrica. Entretanto, a grande maioria deles não faz constar essa etapa na redação final dos seus escritos. Apolônio e até mesmo Euclides - cuja obra (Elementos) é tida como o grande modelo de exposição sintética - assumem a existência de uma etapa analítica que precede a exposição sintética, mas que, no entanto, é suprimida. Progressivamente, a síntese passa a ser considerada isoladamente como o sistema axiomático de uma disciplina, sem qualquer dependência ou relação explícita com uma etapa analítica prévia. Pappus, ao contrário, não apenas preserva a parte analítica da resolução dos problemas, como fornece a descrição mais completa do método de análise a que os matemáticos do séc. XVII tiveram acesso. Por essa razão, ele é citado por Descartes como representante da análise dos antigos, no que diz respeito ao seu alcance geométrico. Diofanto, igualmente citado por Descartes, utiliza o procedimento de análise aplicado, porém, às quantidades algébricas. Por isso, ele pode ser considerado um "pré-algebrista" ou um precursor da álgebra dos modernos. Sua contribuição mais significativa para os fundamentos da álgebra está na introdução das noções de "quantidade desconhecida" e de "equações" tomadas como uma relação entre o que é dado e o que é preciso determinar.

No entanto, ao mencionar os homens do "nosso século", Descartes refere-se aos algebristas modernos, responsáveis pelo desenvolvimento dessa ciência cujos primeiros fundamentos aparecem em Diofanto. Entre eles, destaca-se Viète, que se autodeclara continuador da tradição dos praticantes do método de análise. Viète escreveu um breve texto intitulado In artem analyticam isagoge (1591), em que ele apresenta como objetivo estabelecer uma relação entre o método de análise apresentado por Pappus (relativo às grandezas geométricas) e o método de Diofanto (que trata das grandezas algébricas). Essa "arte analítica" possui duas características principais: a formulação de 
uma noção mais clara de equação e a recuperação e reavaliação da estrutura do método de análise dos geômetras antigos. Parece haver um consenso, levando-se em conta as posições tanto de Viète quanto de Descartes, sobre o papel do procedimento analítico dos geômetras antigos na gênese metodológica da álgebra dos modernos. Com efeito, a álgebra não acrescenta nada ao método de análise propriamente dito; porém, amplia-lhe o escopo, permitindo que ele seja aplicável aos cálculos algébricos.

Via de regra, o passo inicial de qualquer procedimento analítico de resolução de problemas é supor o problema resolvido. Com efeito, não se trata de um simples expediente de ordem retórica, pois esse passo permite que a análise utilize o elemento pedido (no enunciado do problema) no exame das relações que integram a complexidade do problema. O propósito da análise é o de estabelecer relações entre todos os possíveis elementos do problema, sejam eles fornecidos ou procurados, até que se encontre uma relação que não dependa da suposição inicial (de que o problema já está resolvido) para, então, determinar o desconhecido em função do conhecido (ver a solução de Descartes ao problema de Pappus, a seguir). A novidade que o método cartesiano de análise pretende trazer é a de fornecer um procedimento que permita, a qualquer um que o siga corretamente, desmembrar a complexidade do problema e ordenar sistematicamente as relações entre seus elementos, a fim de encontrar o que é procurado. Pode-se resumir assim o propósito da mathesis universalis exposta por Descartes nas Regras como uma ciência que se caracteriza, principalmente, por seu método analítico.

Para fornecer uma definição mais precisa da mathesis universalis, Descartes utiliza-se da seguinte questão: o que precisamente se entende por matemática? Em outras palavras, por que a astronomia, a música, a óptica, a mecânica e tantas outras se dizem partes das matemáticas? O que há em comum entre todas elas e as faz 
reconhecidamente matemáticas é o fato de que, nelas, se examinam a ordem e a medida de seus objetos. Esse ponto em comum é que deve ser a base de uma ciência que se pretende geral a ponto de abarcar todas as demais. Daí a definição da mathesis universalis como aquela "ciência geral que explica tudo quanto se pode procurar referente à ordem e a medida, sem as aplicar a uma matéria especial” (Descartes, 1999, p. 27).

O cerne da mathesis universalis, a ordem e a medida, não é tomado de empréstimo, segundo o que pudemos ver acima, das matemáticas comuns (pois elas não constituem um modelo metodológico, mas apenas de certeza e precisão). Ele vem, isto sim, da constatação do elemento mais geral e comum a todas as disciplinas que se pretendem matemáticas. Por isso, a mathesis universalis estende-se a todas elas contanto que se dominem as regras de sua operacionalização. Não por acaso, a Regra V apresenta a seguinte definição para o método: "O método todo consiste na ordem e na organização dos objetos sobre os quais se deve fazer incidir a penetração da inteligência para descobrir alguma verdade" (Descartes. 1999. p.29). Vê-se, então, que a mathesis universalis é definida por seu método, e não poderia ser diferente, pois ela nada mais é que um conjunto de procedimentos metodológicos inspirados no potencial heurístico sui generis típico das matemáticas. É justamente a partir da Regra V que Descartes passa a fornecer uma "teoria do método" propriamente dita. O comentário que se segue ao enunciado da regra é curto, porém enfático ao destacar o caráter absoluto do método e a extrema importância que lhe deve ser atribuída:

Nós lhe ficaremos ciosamente fieis [ao método], se reduzirmos gradualmente as proposições complicadas e obscuras a proposições mais simples, e, em seguida, se, partindo da intuição daquelas que são as mais simples de todas, procurarmos elevar-nos pelas mesmas etapas ao conhecimento de todas as outras. (Descartes, 1999, p. 29). 
Para descobrir algo de verdadeiro, é preciso ordenar e dispor os objetos: eis o resumo do método. Ordenar significa operar uma redução das proposições complicadas às mais simples e, em seguida, proceder uma elevação das mais simples, percorrendo os mesmos passos, até as mais complexas. A nova complexidade que surge daí está, então, reconstituída e totalmente compreendida. Esse procedimento, portanto, não está restrito ao caráter analítico, pois contempla uma parte sintética: aquela que vai do simples ao complexo. Diante disso, como se pode conciliar a parte sintética assumida pela Regra V e aquela crítica ao procedimento sintético exposta anteriormente? Descartes não nega ao procedimento sintético suas características de clareza e precisão. Entretanto, tal procedimento não acrescenta nada àquilo que já é conhecido, apenas serve como prova do que já se sabe. Nesse sentido, é a etapa analítica do método que se presta propriamente à solução do problema considerado, pois tem como finalidade encontrar os elementos desconhecidos mais simples desse problema. A etapa sintética retorna à complexidade já conhecida, a fim de ordená-la, mas com isso não produz nenhum conhecimento novo.

A Regra VI acrescenta à descrição dessas duas etapas do método a noção de disposição dos objetos em forma de séries, fornecendo os meios para que se possam submeter ao método ordens mais complexas, nos termos do texto, ordens obscuras e intrincadas. Isso porque nem sempre o problema possui um grau de facilidade tal que sua ordem seja por si evidente. Segundo Descartes, a disposição dos objetos em séries é, ao mesmo tempo, a grande utilidade e o segredo do método.

O método, considerado assim, não nos autoriza o acesso direto à natureza de cada coisa a fim de encerrá-las em categorias ou, nas palavras de Descartes, "gêneros de ser”, pois ele é relação entre coisas. Ao deduzir um objeto desconhecido de outro já conhecido, não se chega a um novo gênero de ser, pois, para que haja qualquer tipo de 
comparação, um objeto deve participar de algum modo da natureza do outro. Mas, a fim de melhor caracterizar o conhecimento como um processo de comparação, é necessário estabelecer uma diferença entre as comparações simples e as outras (complexas). As primeiras são aquelas em que o que se procura e o que é fornecido participam de modo idêntico de uma certa natureza. Nesse caso, praticamente não resta ao espírito nenhuma operação. Porém, pode ocorrer que a natureza comum, requisito para a comparação entre os objetos, não se encontre de maneira idêntica em ambos, mas seguindo relações ou proporções. A tarefa do espírito, então, é transformar essas proporções de maneira a evidenciar o que há em comum entre o que se procura e o conhecido. "Quase toda a indústria da razão humana consiste em preparar essa operação” (Regra XIV).

As regras iniciais, ao fornecerem as bases epistemológicas para a metodologia, garantem a possibilidade de se estabelecer um método único aplicável a todas as ciências. Nisto se resume o grande projeto da mathesis universalis, uma ciência geral que pretende investigar a ordem e a medida, qualquer que seja o objeto considerado. A realização desse projeto no campo das matemáticas é tida como certa e imediata, já que seus objetos são os mais simples de todos. Entretanto, como vimos, Descartes confere ao método a possibilidade de se ampliar o domínio do conhecimento para além das disciplinas matemáticas.

Portanto, o projeto da mathesis universalis, de certo modo, antecipa o que será a prática matemática de Descartes em sua maturidade. O caráter metodológico dessa ciência não deixa dúvidas quanto à sua opção pelo método analítico; uma opção que, no que se refere às ciências matemáticas, será consolidada por Descartes em sua obra Geometria. Ou seja, pode-se dizer que o primeiro passo da aplicação do método ou, em outras palavras, da realização do projeto da mathesis universalis, é dado no âmbito das 
matemáticas $^{5}$. A Geometria (1637) tem como objetivo traduzir propriedades geométricas em operações algébricas. A realização desse programa promove uma unificação ordenada dos domínios matemáticos, ou seja, promove entre as matemáticas, cujos objetos são os mais simples, aquilo que a mathesis universalis pretende estender para todas as ciências ${ }^{6}$.

\subsection{Análise cartesiana: a matemática como disciplina na Geometrie}

A teoria das proporções citada nas obras cartesianas é, sem dúvida, a teoria das proporções exposta nos Elementos de Euclides. No entanto, a fim de compreender tal teoria, é necessário, primeiramente, fazer uma importante distinção. A teoria das proporções, da maneira como é exposta por Euclides, possui duas fontes distintas: Eudoxo (apresentada no Livro V) e Teeteto (apresentada no Livro VII).

Quantidades e formas geométricas são as duas classes de objetos admitidos nas matemáticas gregas. Autores como Apolônio e o próprio Euclides admitem tratar os objetos geométricos como grandezas, a fim de estudar as suas propriedades a partir das suas relações de igualdade, similitude ou proporção. O Livro I dos Elementos pode nos fornecer exemplos desse tratamento: "Ângulo obtuso é o que é maior que o ângulo reto" (Elementos, I, Def. XI), “O triângulo isósceles é o que tem somente dois lados iguais”

\footnotetext{
${ }^{5}$ Segundo Jullien (1996, p.36), “A constituição de um domínio unificado e ordenado dos diversos ramos das matemáticas é, todavia, um objetivo intermediário importante ou mesmo necessário do projeto geral" [unificação das ciências].

${ }^{6}$ No que diz respeito às demais ciências do mundo físico, a noção de matematização da natureza que se pode retirar das Regulae não deve ser entendida como uma simples duplicação matemática dos objetos físicos ou de suas propriedades. A inspiração matemática do método de Descartes exige que os objetos sejam organizados em certas séries e conhecidos uns pelos outros. O que se pode disso depreender pouco tem a ver com a natureza intrínseca de cada um dos membros da série tomados individualmente ou como espécies. Um modo alternativo de compreender o ideal mecanicista segundo o qual todos os mecanismos da natureza devem ser explicados em função do movimento e das qualidades geométricas da matéria é tomá-lo como um desdobramento da ontologia relacional das Regulae. A aplicação dos métodos matemáticos ao mundo físico não resultaria senão na explicitação das relações entre os seus objetos e suas propriedades. Se tais relações são reais ou não, pouco ou nada pode se decidir a esse respeito com base apenas no método ou na matemática - a esse tipo de questões se dedica virtualmente a metafísica. $\mathrm{O}$ decisivo, entretanto, é que não se possa fazer de outro modo, se desejamos nos conduzir pelo método.
} 
(Elementos, I, Def. XXV), "O triângulo escaleno é o que tem os três lados desiguais" (Elementos, I, Def. XXVI), “Todos os ângulos retos são iguais” (Elementos, I, Axioma. XI). Os termos 'maior que', 'iguais' e 'desiguais' expressam relações que são estabelecidas entre quantidades. Mas, nesse caso, o que se pode entender por quantidade?

Entre as matemáticas gregas, não havia uma definição explícita do que sejam quantidades, mas obviamente existe um critério subentendido para estabelecer se determinados objetos, dados como tais, são ou não quantidades. Diz-se que objetos são quantidades se e somente se é possível estabelecer se um deles é maior, menor ou igual a um outro e se é possível reuni-los em novas quantidades homogêneas, o que parece remeter quase que diretamente à teoria das proporções.

Ela - a teoria das proporções - seria, então, uma candidata a oferecer uma "teoria das quantidades em geral" capaz de definir com precisão o que se pode entender por quantidades? A resposta a essa questão não é tão imediata quanto pode parecer. Em primeiro lugar, como já está dito, a teoria das proporções não é constituída de um corpo único, mas está dividida em uma parte que trata dos números (a que tem sua origem em Teeteto) e outra que trata de grandezas (aquela cuja fonte é Eudoxo). Porém, tanto números quanto grandezas são quantidades. Os primeiros possuem claramente uma medida comum: a unidade. As grandezas, por sua vez, não possuem essa tal medida comum. Nem por isso, elas deixam de ser quantidades, já que podem ser comparadas entre si. É justamente essa a distinção entre as duas teorias das proporções.

Por exemplo, para que quatro números estejam em proporção, pressupõe-se que eles cumpram a condição de possuir uma medida comum. Essa condição não é aplicável às grandezas. Segundo a teoria originada com Eudoxo, quatro grandezas $a, b, \alpha, \beta$, sendo duas a duas do mesmo gênero, estão em proporção se e somente se entre todos os 
múltiplos de $a$ e $b$ há a mesma relação de igualdade ou desigualdade que entre os múltiplos correspondentes de $\alpha$ e $\beta$.

$$
\begin{aligned}
& (a: b=\alpha: \beta) \Rightarrow(n a=m b) \Rightarrow(n \alpha=m \beta), \\
& (n a \prec m b) \Rightarrow(n \alpha \prec m \beta),
\end{aligned}
$$

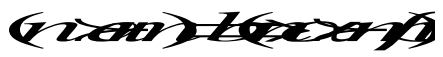

Por outro lado, pela teoria de Teeteto, tem-se que, dados quatro números, é sempre possível estabelecer, por um procedimento finito e geral, se eles estão ou não em proporção. "Quatro números estão em proporção se e somente se o produto do primeiro e do quarto é igual ao produto do segundo e do terceiro" (Elementos, VII, Prop. 19). Ou, em sua formulação mais consagrada, o produto do meio é igual ao produto dos extremos.

$$
\begin{gathered}
a: b:: c: d^{7} \\
a d=b c \\
e=e
\end{gathered}
$$

Assim, afirmar que quatro números estão em proporção é o mesmo que afirmar a igualdade entre dois produtos $(a d=b c)$ ou a igualdade entre outros dois números $(e=e)$. A relação de proporcionalidade, que é uma relação de quatro lugares, torna-se equivalente a uma relação de dois lugares: a igualdade.

O que permite aos números essa passagem da proporcionalidade à igualdade é a sua medida comum, ou seja, a unidade. Considerando as grandezas, pode-se dizer apenas que suas razões são iguais, pois não há um elemento comum que autorize a

\footnotetext{
${ }^{7}$ Essa é uma notação típica da teoria das proporções. A expressão $a: b:: c: d$ significa que $a$ está para $b$ assim como $c$ está para $d$.
} 
comparação entre elas. Este seria, claramente, um obstáculo no que se refere à pretensão de realizar um tratamento algébrico da geometria. Todas as operações algébricas dependem de que se possa levar a cabo aquela passagem da proporcionalidade à igualdade. As grandezas geométricas, no entanto, não possuindo uma unidade, um elemento comum, estariam impedidas de receber um tratamento algébrico. Linhas, áreas e volumes são grandezas contínuas e, consequentemente, devem ser concebidas como totalidades que não resultam da operação de adicionar uma a uma unidades previamente dadas, como somente poderia ocorrer com as grandezas discretas, tais como os números.

A solução cartesiana para esse problema é, sem dúvida, um dos passos mais significativos da Geometria. Descartes escolhe, em cada problema, uma linha-unidade em função da qual podem ser expressas todas as outras.

(...) tendo uma [linha], que nomearei unidade para relacioná-la o melhor possível aos números, e que pode em geral ser tomada arbitrariamente, e tendo logo outras duas para encontrar uma quarta que esteja para uma dessas duas, como a outra está para a unidade, que é o mesmo que a multiplicação (...) (Descartes, 1954, p. 4).

Descartes utiliza-se, aqui, da unidade para o caso da multiplicação. Por imposição da teoria das proporções (Teeteto), a multiplicação requer quatro termos: os dois que propriamente serão multiplicados, a solução da multiplicação e a unidade.

O primeiro livro da Geometria inicia-se com uma seção cujo título é: “Como o cálculo da aritmética se relaciona às operações da geometria” (Descartes, 1954, p. 4), onde Descartes percorre algumas das operações algébricas mostrando de que modo elas podem ser aplicadas aos problemas geométricos. Considerando o caso da multiplicação, tomam-se duas linhas: DB e BC, que são aquelas que se quer multiplicar. Em seguida, escolhe-se uma terceira linha, que será tratada como a unidade: AB. As linhas que serão multiplicadas compartilham um ponto (B) e, portanto, formam um ângulo. 


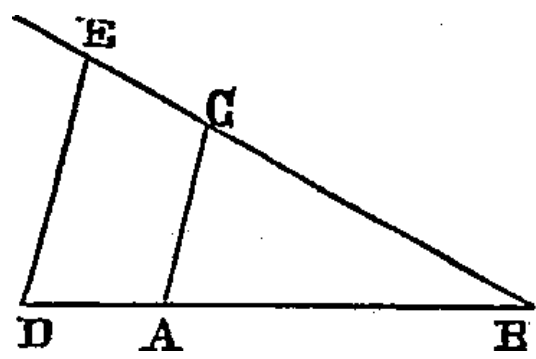

Figura 1

Neste ponto, são conhecidos três dos quatro elementos que formam a proporção, sendo que resta encontrar justamente aquele que será o resultado da multiplicação. Dito de outro modo, tem-se que a unidade $\mathrm{AB}$ está para a linha $\mathrm{BD}$ assim como a linha $\mathrm{BC}$ está para a linha procurada. A figura mostra que esta linha procurada é BE, pois, sendo AC e DE paralelas, BAC e BDE formam triângulos semelhantes e por isso seus lados correspondentes são proporcionais. Em termos da teoria das proporções, BD:AB::BE:BC. Tomando AB como a unidade, BD:1::BE:BC. Igualando o produto dos meios ao produto dos extremos, $\mathrm{BE}=\mathrm{BD} . \mathrm{BC}$ encontrando-se, assim, o resultado procurado. Vemos, pelo que foi apresentado, que somente é possível aplicar a teoria das proporções - exposta no Livro VII dos Elementos - às grandezas geométricas, se for utilizado este expediente de eleger arbitrariamente uma das linhas como unidade.

Assumir essa linha-unidade permite a Descartes realizar a primeira tarefa básica da Geometria: encontrar o correlato geométrico das operações algébricas. Entre essas operações, a soma e a subtração não apresentam qualquer dificuldade, pois não há problema para associar o resultado dessas operações a uma construção geométrica. Entretanto, no que diz respeito à multiplicação, à divisão e à extração de raiz, esta solução não está livre de obstáculos. Por exemplo, dadas duas linhas, seu produto não é imediatamente determinável nem imediatamente passível de ser construído. O mesmo 
se dá quando se pretende encontrar o quadrado, ou raiz, de uma linha, a divisão entre duas linhas ou qualquer operação similar. A determinação dessas operações e a construção de suas linhas-resultado dependem da escolha da unidade; escolha essa que é arbitrária.

No procedimento clássico para a multiplicação de linhas, duas linhas multiplicadas resultam em um plano, ou seja, em uma grandeza perfeitamente determinada e homogênea aos dados. Descartes, por sua vez, utilizando a linha-unidade, põe em risco a homogeneidade das grandezas envolvidas. Por serem geométricas, as linhas são consideradas grandezas contínuas; porém, quando associadas a uma linhaunidade, ganham um caráter discreto. No entanto, isso não faz delas grandezas numéricas, pois, ao contrário destas, sua unidade é arbitrária. Essa nova espécie de grandeza é chamada de "grandeza graduada" e implica em dificuldades exatamente em função da arbitrariedade na escolha da unidade. O problema fica evidente ao se considerar que uma equação que contenha, por exemplo, uma multiplicação entre duas linhas, terá como resultado objetos geométricos distintos, dependendo da escolha da unidade.

A teoria das proporções desempenha um papel fundamental na Geometria. Ela é o meio pelo qual a ciência matemática pode tornar-se unificada, pois permite que seja dado à geometria um tratamento algébrico. O método apresentado nas Regulae consiste justamente em ordenar os objetos e estudá-los segundo a relação de proporção que eles mantêm entre si. Esse núcleo comum, entre o projeto da mathesis universalis e a unificação das matemáticas operada na Geometria, suscita a questão de saber em que medida esta última é a realização da primeira.

A mathesis universalis é caracterizada como a ciência das relações que deveria presidir todas as ciências das quantidades particulares; portanto, ela é um projeto geral. 
A constituição de um domínio unificado e ordenado das partes da matemática não esgota a abrangência desse projeto, mas pode ser considerada um importante e necessário objetivo intermediário (Cf. JULLIEN, 1996, p.36). Ela é importante como argumento em favor da possibilidade de constituição daquela ciência geral e necessária como uma espécie de exercício para a aplicação do método a objetos mais complexos, visto que Descartes considera os objetos das matemáticas os mais simples entre todos. Ou seja, essa aplicação inicial do método pode ser considerada como terreno de treinamento no que diz respeito às ciências mais fáceis, em que as noções primeiras são claras e distintas, com vista a alcançar aqueles objetos mais complexos. Então, estando consumada a aplicação do método aos objetos mais simples, não há por que duvidar da possibilidade de que ele seja aplicado aos objetos que encerram maior grau de complexidade.

Finalmente, a Geometria nos oferece um modelo emblemático da opção cartesiana pelo método de análise. Os inegáveis resultados matemáticos promovidos por essa obra servirão de fundamento para a resolução de problemas em diversos autores posteriores a Descartes; Newton entre eles. Entretanto, não obstante tenha aproveitado tais avanços em seus primeiros escritos, Newton acaba por rejeitar o método de análise cartesiano e optar definitivamente por um retorno ao método sintético dos antigos. Os capítulos seguintes tratarão dessa virada metodológica newtoniana.

\subsection{O Problema de Pappus: solução de Descartes}

A importância do problema de Pappus no desenvolvimento da Geometria é indiscutível. Pappus foi um matemático da escola de Alexandria que viveu do final do séc. IV ao início do séc. III a.C. Em seu livro VII da chamada Coleção Matemática, Pappus apresenta um problema que consiste, inicialmente, em encontrar um ponto que 
obedeça a certas condições de proporcionalidade entre as linhas que são traçadas a partir dele em direção a outras linhas dadas. Segundo Pappus, até então ninguém havia conseguido resolver satisfatoriamente tal problema. Euclides forneceu resultados insuficientes e Apolônio, embora também tenha criticado os resultados euclidianos, não forneceu nada além de resultados particulares. Pappus, por sua vez, oferece uma solução mais ampla para o problema; embora, sua solução limite-se a um número máximo de seis linhas dadas.

Uma exposição inicial do problema poderia ser a seguinte:

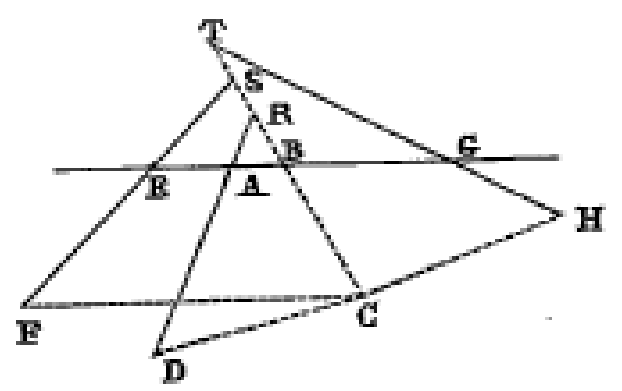

Figura 3

Dado certo número de retas, pede-se para encontrar um ponto (chamado ponto C) a partir do qual seja possível traçar tantas retas quantas foram dadas, de tal modo que as retas traçadas formem um ângulo dado com as retas que haviam sido dadas. Se forem três as retas dadas, o retângulo (produto) formado por duas das retas traçadas deve ser proporcional ao quadrado da terceira. Se forem quatro, o retângulo formado por duas delas deve ser proporcional ao formado pelas outras duas e assim sucessivamente.

Pede-se também que se conheça a linha onde se encontram todos os pontos que satisfazem tais condições. Ou seja, para o mesmo conjunto de retas dadas, há um número indefinido de pontos a partir dos quais se podem traçar outras retas que formam 
ângulo com as primeiras e que cumprem as condições de proporcionalidade descritas acima. A segunda parte do problema consiste justamente em encontrar a linha onde estão situados todos os pontos que são convenientes. Essa formulação do problema apresentada por Descartes não acrescenta nem retira nada do conteúdo do problema abordado por Pappus.

Primeiramente, quatro retas coplanares são dadas em uma determinada posição. São elas: $A B, A D, E F$ e $G H$. Consideram-se os segmentos $C B, C D, C F$ e $C H$ que formam ângulo com $A B, A D, E F$ e $G H$ respectivamente, ligando-os a um ponto $C$. Fixase, então, uma relação entre $C B . C D$ e $C F . C H$. Essa relação é expressa por $\boldsymbol{a}$ na seguinte igualdade: $C B \cdot C D=a \cdot C F \cdot C H$, ou seja, a primeira parte é igual à segunda multiplicada pela relação que elas mantém entre si. Em outras palavras, o produto das duas primeiras retas pode ser igual ao produto das outras duas, mas esses produtos podem ser também apenas proporcionais.

Sendo estas as condições iniciais, pede-se, na primeira parte da solução do problema, que se encontre um ponto $\mathrm{C}$ correspondente à relação determinada. Na segunda, que se encontre a linha onde estão todos pontos convenientes. Isso porque, para uma mesma relação entre $C B . C D$ e $C F . C H$, há diversos pontos que cumprem as condições do enunciado e tais pontos, supostamente, descrevem a linha que se quer encontrar. Esse problema pode estender-se a um número indefinido de linha. Tratarei da solução envolvendo quatro linhas a respeito da qual pode-se dizer que é a soluçãopadrão elaborada por Descartes.

A primeira parte do problema consiste em encontrar um ponto conveniente, ou, em outras palavras, a equação desse ponto. O passo inicial de Descartes é supor que isso já está feito, ou seja, considerar que há ao menos um ponto que atende aos requisitos. Em seguida, destaca dentre as linhas uma que foi dada $(A B)$ e outra pedida $(C B)$ como 
as principais, isto é, aquelas através das quais se podem exprimir todas as outras. $A B$ é chamado de $x$ e $C B$ de $y$.

Considerando o triângulo $A B R$, tem-se que seus ângulos são dados e, por isso, é conhecida a proporção entre quaisquer dos seus lados. Diz-se, então, que a proporção entre $A B$ e $R B$ é a mesma que há entre $z$ e $b$. Assim,

$A B: R B:: z: b$

Substituindo-se $A B$ por $x$ e igualando o produto dos meios ao produto dos extremos, obtemos o seguinte:

$$
\begin{aligned}
& x b=z R E \\
& R B=\frac{b x}{z} .
\end{aligned}
$$

A linha $C R$ é igual à soma das linhas $C B(=y)$ e $R B$, que é igual a $\frac{b x}{z}$, ou seja,

$$
C R=y+\frac{b x}{z}
$$

notando que se o ponto $R$ estivesse entre $C$ e $B, C R$ seria igual a $y-\frac{b x}{z}$ e se $C$ estivesse entre $B$ e $R, C R$ seria $-y+\frac{b x}{z}$.

Tomando-se, agora, o triângulo $D R C$, é fácil notar que se pode utilizar o mesmo procedimento: já que seus ângulos são dados, é dada também a proporção entre seus lados. Diz-se que $C R$ está para $C D$ assim como $z$ está para $c$. Temos, então, que se:

$$
\text { z. } C D=c . C R \text {, }
$$


então

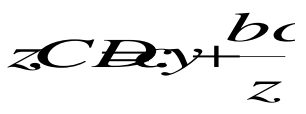

e, consequentemente

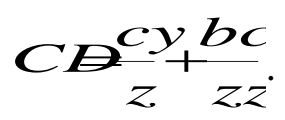

Esse processo pode se repetir para todas as linhas, pois todas elas são dadas em posição, ou seja, os ângulos que elas formam são conhecidos. Desse modo, Descartes fornece a maneira de expressar todas as linhas envolvidas no problema, das quais ainda restam as seguintes:

$$
\begin{aligned}
& B S=\frac{d k+d x}{z}, \\
& C S=\frac{z y+d k+d x}{z} z, \\
& C F=\frac{e z y+d e k+d e x}{z}, \\
& C T=\frac{z y+f l-f x}{z}, \\
& C H=\frac{g z y+f g l-f g x}{z z} .
\end{aligned}
$$

Porém, o que há em comum entre as linhas que partem do ponto $C$ ? Todas elas podem ser expressas, de modo geral, por três termos precedidos de + ou - , dependendo da localização dos pontos: um composto por $y$ (quantidade desconhecida) multiplicado ou dividido por uma quantidade conhecida, outro composto posto por $x$ (quantidade desconhecida) multiplicado ou dividido por uma quantidade conhecida e, por fim, por 
uma quantidade inteiramente conhecida. Então, pode-se dizer que cada uma das linhas pode ser representada por uma expressão algébrica do tipo:

$$
a y \pm b x \pm c
$$

sendo $a, b$ e $c$ conhecidos.

Nesse caso, $x$ ou $y$ podem ser nulos se a linha for paralela a uma das linhas tomadas como base. Assim, ao multiplicarmos duas dessas linhas, $x$ e $y$ estarão elevados no máximo ao quadrado, ou, nas palavras de Descartes, terão até duas dimensões (lembrando que se uma das linhas for paralela, $x$ ou $y$ serão nulos). Se o produto for entre três linhas, terão até três dimensões e assim por diante. Descartes pode mostrar, agora, que para até cinco linhas, o problema não vai além da geometria plana (o que contraria a resposta dada por Pappus ao problema).

Obedecendo ao enunciado do problema, para se encontrar o ponto C, para o caso de cinco linhas dadas, é necessário que o produto das três primeiras linhas seja igual ou proporcional ao produto das outras duas multiplicado, ainda, por uma sexta linha dada

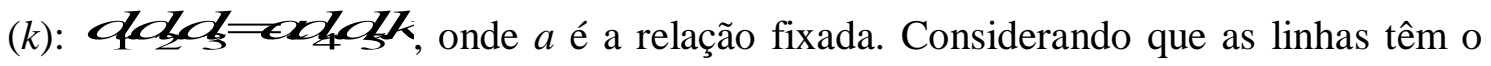
formato $a y \pm b x \pm c$, a sua multiplicação resultará, no primeiro membro, em um polinômio de grau 3 em y e 2 em $x$ (já que uma das linhas é BC que é igual a $y$, ou seja, não depende de $x$ ); no segundo membro, um polinômio de grau 2 em $y$ e em $x$ (pois $k$ é uma linha conhecida). Em seguida, é fixado o valor de $y$, ou seja, uma quantidade conhecida é tomada por $y$, o que faz resultar na seguinte equação: $x^{2}=\underline{t a x+b^{2}}$. Isso mostra por que não é necessário ir além da geometria plana para o caso de cinco linhas dadas: o grau da equação determina o gênero da curva, de tal modo que a equação de segundo grau corresponde a uma curva traçada na geometria plana, enquanto uma de terceiro grau representa uma curva que necessita da geometria dos sólidos. 
Desse modo, no que se refere ao problema de Pappus, fica fácil identificar em seu desenvolvimento os vários passos da etapa analítica e sua primazia com relação à síntese. Tendo exposto o enunciado do problema, Descartes supõe que ele já está resolvido, ou seja, considera que existe um ponto $C$ que cumpre as exigências do enunciado. Foi dado, assim, o primeiro passo da análise. Em seguida, ele nomeia todas as linhas envolvidas e destaca duas dentre elas: $A B$, identificada a $x$ e $C B$, identificada a y. Então, determina a equação de cada uma das linhas e as reduz, como mostrado acima, a uma única equação da forma.

Ao eleger duas linhas retas como principais, Descartes as está transformando em variáveis que determinam a curva, ou lugar geométrico, que soluciona o problema. Esse procedimento - que consiste em atribuir a cada linha uma variável - confere um alto grau de generalidade à solução de problemas. Assim, a equação encontrada por esse meio dispensa a identificação de um número considerável de pontos para a construção da curva. Ao invés disso, a equação fornece os elementos característicos da curva. Portanto, a etapa analítica do método é aquela que reduz a complexidade de um problema a um objeto simples: a equação. A partir dessa equação, pode-se proceder à construção do problema, reorganizando a complexidade, antes não compreendida, em um corpo inteligível e ordenado.

\subsection{A ontologia cartesiana dos objetos matemáticos}

Ao considerarmos a diferença entre o que Descartes chama de verdadeiras matemáticas, ou seja, a matemática que serve como modelo metodológico e as matemáticas comuns, algumas questões se impõem quando o que se quer investigar é a ontologia dos objetos matemáticos. A primeira delas diz respeito à relação que se 
estabelece entre a mathesis universalis e a Geometria. Será que podemos afirmar que ambas constituem o mesmo programa? Segundo Jullien (1996, p. 35-51), a resposta é não. A primeira pretende, como vimos, estabelecer uma ciência universal, através de um método universal. A segunda unifica dois domínios até então distintos das matemáticas. Entretanto, essa resposta negativa parece assinalar não uma contradição entre esses dois projetos, mas, isso sim, uma diferença de escopo. Pois, se por um lado, como diria Vuillemin (1987, p. 10), “a invenção da geometria analítica parece secundária em comparação com a invenção de um método universal de pensamento", essa geometria compartilha com o método em questão um núcleo comum e essencial: a teoria das proporções.

A mathesis universalis, conforme vimos na seção 1.1, como ciência das relações quantitativas, pretende unificar todas as ciências das quantidades particulares. Das matemáticas, ela toma certos "tesouros metodológicos" $"$ : são inúmeros os exemplos tomados da matemática pelas Regulae e integrados à mathesis universalis, como parte constitutiva de seu método. Tais exemplos evidenciam a centralidade da teoria das proporções para o método universal. O princípio desse método se resume a percorrer as coisas que se pode conhecer, segundo a ordem das relações que elas mantêm entre si. Esse mesmo princípio conduz a Geometria, mas, nesse caso, formalizado pela teoria das proporções dos geômetras antigos. Aliás, como veremos adiante, tal característica permite-nos afirmar que Descartes jamais saiu do âmbito da geometria, ainda que tenha acrescentado inúmeras novidades ao uso da teoria das proporções. Assim, as matemáticas fornecem um conteúdo metodológico à mathesis universalis. Por outro lado, possuem, elas próprias, um conteúdo enquanto disciplinas.

\footnotetext{
${ }^{8}$ Tomo de empréstimo o vocabulário de Jullien (1996).
} 
No projeto geral, das Regulae, de uma ciência que reúne todas as ciências das quantidades, unificar e ordenar o domínio das matemáticas parece consistir em um objetivo intermediário. Isso porque, por serem claras e distintas, as noções das matemáticas constituem um campo mais fácil de aplicação do método universal. Por essa razão, o sucesso conseguido nesse primeiro passo em direção à ciência geral e unificada consiste em um forte argumento em favor da possibilidade de alcançar o objetivo mais geral. Entretanto, o que queremos e precisamos garantir, aqui, não é exatamente o sucesso desse passo intermediário, mas a sua inserção no projeto das Regulae. Afirmar que a matemática cartesiana, entendida como disciplina e desenvolvida na Geometria, está em consonância com o projeto da mathesis universalis, ainda que como um passo inicial e intermediário, significa afirmar que a ontologia dos objetos do conhecimento em geral que opera nas Regualae é aplicada aos objetos matemáticos. Chega-se então, à questão colocada no início da seção.

Diante da pluralidade de abordagens relativas à ontologia das Regulae, escolhemos uma alternativa que, embora distante de consistir em unanimidade entre os comentadores, fornecerá um excelente parâmetro para o desenvolvimento da nossa questão principal, a saber, a da ontologia dos objetos matemáticos extraída dos textos de Isaac Newton. Trata-se da abordagem de Jean-Luc Marion, mais especificamente aquela desenvolvida em seu livro intitulado Sur l'ontologie grise de Descartes ${ }^{9}$. Tratamos anteriormente do deslocamento do centro de gravidade do conhecimento, que deixa o objeto para se instaurar no sujeito que conhece, ou seja, na razão. Esse deslocamento,

\footnotetext{
${ }^{9}$ É preciso esclarecer que a escolha desse texto, e das teses que ele sustenta, é pautada pelo objetivo final que é o de analisar a ontologia dos objetos matemáticos newtonianos. A discussão da matemática e da ontologia de Descartes tem como único objetivo oferecer um parâmetro a partir do qual se possa estabelecer um paralelo com a matemática e a ontologia de Newton e, assim, extrair elementos que não se encontram na superfície dos textos newtonianos. É com esse mesmo propósito que emprestamos, aqui, a "ferramenta de leitura" oferecida por Marion para se compreender o texto das Regulae, visando a posterior comparação com as teses de Newton. Portanto, não faz parte do escopo desta pesquisa a avaliação da validade dessa leitura da obra de Descartes. Por outro lado, as teses de Marion a respeito das Regulae servirão como ferramenta para expor a questão da ontologia dos objetos matemáticos newtonianos.
} 
operado pelas Regulae, gera consequências ontológicas importantes, tratadas exaustivamente por Marion. Segundo ele, as Regulae se desenvolvem em torno de um diálogo não declarado com a filosofia de Aristóteles, no qual Descartes teria abandonado a ousía (substância) aristotélica, substituindo-a pela relação estabelecida pela razão entre os objetos do conhecimento ${ }^{10}$ :

Aristóteles constitui uma tal ciência por referência à ousia, Descartes, por referência à humana universalis Sapientia. O que indica, talvez, que doravante o ego substitui a ousia enquanto termo último de referência e de constituição do corpo das ciências. E é sem dúvida por isso que se pressente desde agora que o estatuto do ego epistemológico só pode, nas Regulae, conquistar-se à custa da destruição total e sistemática do primado aristotélico da ousia, tanto como fundamento da coisa, como princípio da ciência. (Marion, 1975, p. 44)

A tese de Marion sustenta que a anterioridade atribuída por Aristóteles ao objeto, com relação ao saber do objeto - e, portanto, do particular com relação ao universal - é substituída, em Descartes, por uma anterioridade do universal: a primazia da sabedoria humana estabelecida pela Regra I. Por ser anterior às particularidades, essa sabedoria humana só pode dedicar-se a uma ciência universal que abarca a todas as outras e cujas características e critérios são aplicados indistintamente. O sujeito cognoscente torna-se, então, o princípio do saber e a instância capaz de decidir sobre o escopo e o método dessa ciência universal.

Quanto ao escopo, dado que o princípio foi transferido do objeto para o sujeito, o único critério possível é epistemológico. A certeza vai desempenhar esse papel como critério interno à própria ciência universal, ou seja, como critério que não pertence ao objeto. Diz a Regra II que "Toda ciência é um conhecimento certo e evidente" (Descartes, 1999, p. 5). Assim, não pode haver uma modalidade epistemológica que contemple o incerto ou, até mesmo, o provável. Sendo o fundamento desse critério estabelecido no interior da ciência, qualquer falha, por minimamente duvidosa que seja,

\footnotetext{
${ }^{10}$ Para uma crítica da interpretação de Marion a respeito desse ponto, cf. Loparic (1997, p.159-71).
} 
representa uma ameaça, pois, sendo que todos os objetos são externos ao critério, nenhum deles pode fornecer correção à ciência. Aquilo que não se apresenta ao espírito de maneira certa e evidente está definitivamente fora do escopo da ciência universal. Trata-se de um critério que exclui da ciência o que ela não pode conhecer com certeza, ignorando ou tomando como inexistente o que escapa ao critério de certeza.

Já quanto ao método, Descartes o resume na Regra VI:

Todas as coisas podem ser distribuídas em certas séries, não por certo na medida em que as reportamos a algum gênero de ser, segundo a divisão que deles fizeram os Filósofos em suas categorias, mas na medida em que podem ser conhecidas umas pelas outras, de tal maneira que, cada vez que encontramos uma dificuldade, possamos de imediato perceber se é útil passar antes em revista algumas outras e quais delas e em que ordem. Para que se possa fazer isso como se deve, temos de notar em primeiro lugar que todas as coisas - do ponto de vista que pode torná-las úteis ao nosso desígnio, em que não consideramos suas naturezas isoladas, mas em que as comparamos entre si a fim de conhecê-las umas pelas outras - podem ser denominadas absolutas ou relativas (Descartes, 1999, p. 31).

Conhecer, portanto, é organizar as coisas em séries segundo a ordem e a medida, de modo que só é possível aplicar o método da ciência universal às coisas que se submetem a essa ordem e medida. Todo o resto pode ser ignorado. Ou seja, mesmo o método funciona como critério que, ao invés de acrescentar evidências à ciência, determina tudo o que deve sair de seu escopo: é um método restritivo. Pode-se perceber o diálogo inconfesso com Aristóteles, a que se refere Marion, quando Descartes afirma que as séries não consistem em gêneros de ser ou nas categorias dos Filósofos (substância, atributo, etc). Trata-se de considerar a relação que as coisas mantêm entre si e conhecê-las através dessa relação. Não é a própria natureza das coisas que se oferece para a comparação, mas a sua inteligibilidade, pois, para serem comparadas, o único elemento, externo ao sujeito cognoscente, que elas precisam ter em comum é a extensão. Sendo assim, a relação que se estabelece é estritamente de quantificação, visto 
que nenhuma outra particularidade essencial das coisas é considerada na relação. Por essa razão, a teoria das proporções exerce um papel importantíssimo na mathesis universalis, como dito acima. A questão que se põe, então, é a de saber de que modo a matemática cartesiana - cujo núcleo é, igualmente, a teoria das proporções corresponde às exigências dessa ciência universal e organiza seus objetos segundo tais critérios.

Primeiramente, a matemática de Descartes, exposta na Geometrie, não constitui uma teoria matemática diversa da geometria, considerada em seu sentido estrito. Seus problemas são os problemas da geometria e o mesmo vale para seus objetos. Porém, é preciso estabelecer uma distinção entre os objetos matemáticos e a ontologia desses objetos. Por exemplo, dois autores podem definir de maneira idêntica a linha como gerada pelo movimento de um ponto, sem, contudo, estarem comprometidos com a mesma interpretação ontológica dessa definição. Enquanto que o primeiro pode considerar esse movimento como um mero constructo da imaginação, o outro pode atribuir-lhe um grau de realidade equivalente ao da natureza. Claro que, nesses termos, são casos extremos que, no entanto, ilustram o ponto em questão. Desse modo, resta-nos precisar as nuances da ontologia que os objetos matemáticos assumem, para Descartes, com vistas a possibilitar um paralelo com a matemática newtoniana e sua respectiva ontologia.

Ao considerar a afirmação de Jullien de que a Geometrie, embora não realize completamente o projeto das Regulae, constitui um passo intermediário e, portanto, uma parte desse programa, aquilo que afirmamos a respeito dos objetos do conhecimento em geral será licitamente aplicado aos objetos da matemática cartesiana. Isso significa que, ainda que estejamos no âmbito dos objetos considerados pela geometria euclidiana, não há um comprometimento com a natureza de tais objetos. Na medida em que eles são 
devidamente submetidos à teoria das proporções, os objetos matemáticos são admitidos no escopo da ciência que deve, por sua vez, estabelecer as relações que eles mantêm entre si, não estando obrigada a afirmar nada a respeito da natureza desses objetos. Essa característica, própria de um critério epistemológico de admissão dos objetos, permite a Descartes uma grande liberdade na utilização do formalismo (Viète) presente na resolução dos problemas, como no exemplo do problema de Pappus, desenvolvido acima.

Desse modo, dada uma curva qualquer, a análise da equação atribuída a essa curva permitirá encontrar os elementos característicos da curva como a tangente, por exemplo. Em muitos casos, a construção da curva torna-se dispensável, ou ao menos secundária. Isso não descaracteriza a matemática da Geometrie como geométrica, no sentido estrito, pois os objetos permanecem geométricos. Entretanto, aquilo que o conhecimento matemático pretende atingir é a relação entre tais objetos, o que está totalmente preservado pela equação. É importante destacar que não se trata, aqui, de um instrumentalismo, strictu sensu. Embora o critério para a admissão de objetos ao conhecimento não esteja fundamentado nos próprios objetos, ele não é, tampouco, arbitrário. O critério de certeza não é universal apenas na medida em que se aplica a todas as ciências. Ele guarda, da mesma maneira, um caráter intersubjetivo, pois, contanto que o método seja seguido sem desvios, todo e qualquer ser dotado de razão alcançará o mesmo grau de certeza para as mesmas coisas consideradas.

Com os elementos reunidos até aqui, têm-se construído um parâmetro a partir do qual pode-se pensar a ontologia dos objetos matemáticos newtonianos, comparando a prática matemática de Newton com a de Descartes, afim de extrair os critérios ontológicos subjacentes às opções da prática matemática newtoniana. 


\section{APRESENTAÇÃo ANALítica DO MÉTODO DAS FLUXÕES}

\section{DE NEWTON}

Abordo, a seguir, a fase inicial dos estudos matemáticos de Newton, canonicamente chamada pelos comentadores de fase analítica da obra newtoniana. Ela se inicia nos primeiros escritos matemáticos do autor e termina no começo dos anos de 1670, quando Newton teria retornado à geometria dos antigos. Entretanto, apesar de a maioria dos comentadores concordar com tal delimitação histórica, ponho em questão em que reside a unidade, especialmente metodológica, reivindicada para tal período. Com esse propósito, o presente capítulo está dividido em duas partes, confrontando dois textos escritos nessa etapa e que, no entanto, apresentam vias diferentes para a solução de problemas semelhantes. O primeiro é um manuscrito conhecido como Tratado de Outubro de 1666. A solução do problema das tangentes, exposto nesse texto, apresentase como um caso paradigmático da utilização, por Newton, de recursos estritamente geométricos em um período anterior à suposta retomada da geometria dos antigos. A evidência de que o apelo à geometria não está restrito à maturidade do autor redimensiona, portanto, o problema de saber se há uma ruptura na passagem para a outra fase da prática matemática de Newton. A segunda parte volta-se, então, para o texto que concentra a apresentação analítica do método das fluxões: o De Methodis. O desenvolvimento dos dois problemas iniciais dessa obra expõe os procedimentos algorítmicos utilizados por Newton, fornecendo o conteúdo que servirá de parâmetro a ser comparado com a chamada fase sintética da matemática newtoniana. 


\subsection{Tratado de 1666}

Tendo esclarecido o que se entende por análise, ao se referir à matemática newtoniana, cabe a tarefa de explorar os escritos matemáticos iniciais de Newton, a fim de pôr em evidência o uso da análise em sua prática matemática. Para tanto, considero o período anterior ao Tratado de Outubro de 1666; abordando, principalmente, a natureza dos problemas que mereceram a atenção de Newton nessa época. Por fim, volto-me ao texto do Tratado, considerado uma redação prévia que, revisada, teria dado origem ao De Methodis. Entretanto, para os propósitos aqui apresentados, são justamente as diferenças entre eles que serão exploradas.

O início dos estudos matemáticos de Newton tem como objeto principal as curvas sobre as quais ele aplica o formalismo - em parte cartesiano, em parte expandido posteriormente pelo próprio Newton -, pressupondo a possibilidade de referir essas curvas a coordenadas retilíneas. O importante a ser considerado a respeito de tais objetos é que eles permanecem como legítimos objetos geométricos, uma vez que a condição a ser satisfeita se refere a certas propriedades geométricas da curva em questão e não às propriedades algébricas de sua equação. Até este ponto, a álgebra geométrica de Descartes não foi extrapolada, a não ser por um ou outro algoritmo acrescentado. No entanto, considerações cinemáticas passam a ocupar um lugar de destaque nos interesses matemáticos de Newton. A primeira delas diz respeito à composição de movimentos.

Diante do problema de determinar quantitativamente o movimento pontual de um corpo do qual se conhece a direção em cada ponto (conhecido como problema das velocidades pontuais), Newton constata a possibilidade de aplicar a esse problema cinemático o algoritmo que desenvolvera para o problema das tangentes, contanto que os corpos considerados descrevam segmentos cuja relação é conhecida e pode ser 
expressa por equações algébricas. A ideia geral de um vínculo entre esses dois problemas estava presente no "método das tangentes de Roberval", ao qual Newton teve acesso somente após ter concluído tal relação. Porém, embora tenha ficado conhecido como um método, ele não consistia em um procedimento claro para solucionar um dos problemas através de seu vínculo intrínseco com o outro. Consistia, ao contrário, em uma imprecisa enunciação de tal vínculo acompanhada da exposição de um caso particular. Newton dedica três notas ao método das tangentes de Roberval e, partindo desse estudo, confere a generalidade da qual o método estava carente, através do que nomeamos, atualmente, como método do paralelogramo.

O objetivo principal dos esforços subsequentes de Newton é justamente o de alcançar a generalidade capaz de tratar de todo movimento composto através de uma mesma modalidade de composição do movimento. Newton nomeia por $x$ e $y$ dois segmentos variáveis descritos por dois movimentos. A seguir, chama de $p$ e $q$, respectivamente, as velocidades pontuais desses movimentos. Através da equação que relaciona $x$ e $y$, chega-se à seguinte igualdade:

$$
\frac{p}{q}=\frac{s t g_{x}}{y}
$$

que relaciona as velocidades à subtangente de um dos segmentos; porém, ainda não esclarece o vínculo entre o problema das tangentes e o da velocidade. Posteriormente, ao tratar do problema da tangente da curva logarítmica, Newton chega a uma observação importante. Tomando-se um ponto qualquer da curva (dada em coordenadas cartesianas), a tangente da curva nesse ponto pode ser interpretada como a diagonal de um paralelogramo construído sobre dois segmentos, cuja origem é o ponto em questão. Tais segmentos representam as velocidades pontuais dos movimentos de incremento das coordenadas às quais a curva se refere. 


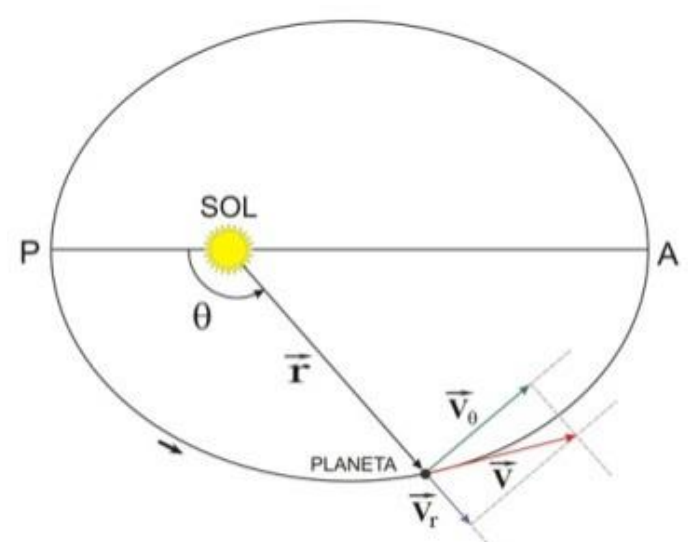

Figura 3: método do paralelogramo.

Newton estabelece, por fim, o vínculo intrínseco entre os dois problemas (o da velocidade e o da tangente) e tal vínculo não poderia ser extraído como consequência de nenhum dos algoritmos até então utilizados nas soluções desses problemas. Isso atrai a atenção de Newton para considerações geométricas entrelaçadas com considerações cinemáticas e independentes da álgebra geométrica cartesiana. Segundo Panza, esse resultado gera duas consequências importantes:

(a) se a curva pode se expressar mediante uma equação algébrica, a equação poderia ser entendida como a expressão de relação entre os segmentos, $x$ e $y$, gerados por dois movimentos distintos, os quais, (...), produzem um terceiro movimento que por sua vez gera a curva; (b) o caso de uma curva expressa por uma equação algébrica, relativa a um sistema de coordenadas cartesianas, não é senão um caso particular de todos os casos que se podem estudar e resolver fazendo referência ao resultado anterior; tal resultado não tem de fato nada a ver com as equações algébricas e tem a ver, na mudança, com invariantes geométricos expressados pelos segmentos $p$ e $q$ (que representam as velocidades pontuais)". (PANZA, 2001, p. 39)

A redação do Tratado de Outubro de 1666 se dá no contexto descrito acima. A partir de maio de 1666, Newton inicia uma série de redações com o propósito de desenvolver e explicitar a generalidade da solução geométrica para os problemas cinemáticos de composição do movimento, sustentando que as soluções algébricas são, na verdade, casos particulares. A finalidade de tais notas seria a de produzir um tratado fundado a partir do estudo de movimentos compostos. Na nota de 14 de maio de 1666 , 
Newton anuncia as sete primeiras proposições do que será o Tratado de Outubro de 1666. Dois dias depois, modifica as proposições e acrescenta exemplos. Em outubro de 1666 ele retoma as notas de maio, modificando-as ligeiramente e acrescenta uma nova proposição. Este tratado, ao ser revisado cinco anos mais tarde, resultará na produção do De Methodis.

As seis primeiras proposições do Tratado de Outubro de 1666, de um total de oito, são estudos geométricos da composição de movimento. Em geral, seus problemas são reformulações ou extensões dos "problemas das tangentes e das áreas", alvos privilegiados de grande parte dos matemáticos da época. Entretanto, a sexta proposição extrapola o âmbito de uma reformulação na medida em que apresenta um novo resultado de Newton a respeito da composição dos movimentos. Eis o enunciado da Proposição VI:

Se as linhas ae e $a h$, ao se moverem, interceptam-se continuamente, traço o trapézio $a b c d$ e sua diagonal $a c$. Digo que, ao se determinarem a proporção e posição das cinco linhas $a b, a d, a c, c b$ e $c d$ pelos dados necessários, indicar-se-á a proporção e posição dos cinco movimentos, isto é: do ponto $a$ fixado na linha $a e$ e movendo-se para $b$ e do ponto $a$ fixado na linha $a h$ e movendo-se para $d$; do ponto de intersecção $a$ movendo-se no plano abcd para $c$ (pois essas cinco linhas estão sempre no mesmo plano, apesar de $a e$ e $a h$, eventualmente, só poderem tocar esse plano em seu ponto de intersecção $a$ ); do ponto de intersecção $a$, movendo-se na linha $a h$ paralelamente a $c d$ e de acordo com a ordem das letras $c, d$.

Porém, qual o conteúdo principal do novo resultado exposto por Newton na proposição VI? Novamente, o que está em jogo é a generalidade: resumindo, pode-se dizer que a composição global dos movimentos de $x$ e $y$ - de maneira retilínea - é um caso particular de outra composição global que compreende todos os modos de composição de movimentos. Assim, a curva é considerada, nesse contexto, como o traçado de pontos de intersecção de outras duas curvas. Tais curvas são dotadas de movimentos que, por sua vez, são descritos no plano da curva principal (aquela formada pelos pontos de intersecção das outras duas). Se forem conhecidas as tangentes nos 
pontos de intersecção e as velocidades pontuais das duas linhas, ou seja, os componentes dos movimentos que fornecem o traçado da curva, basta recorrer a uma "simples" construção geométrica para obter a velocidade pontual do ponto de intersecção, pois a direção dessa velocidade será a tangente da curva de todos os pontos de intersecção.

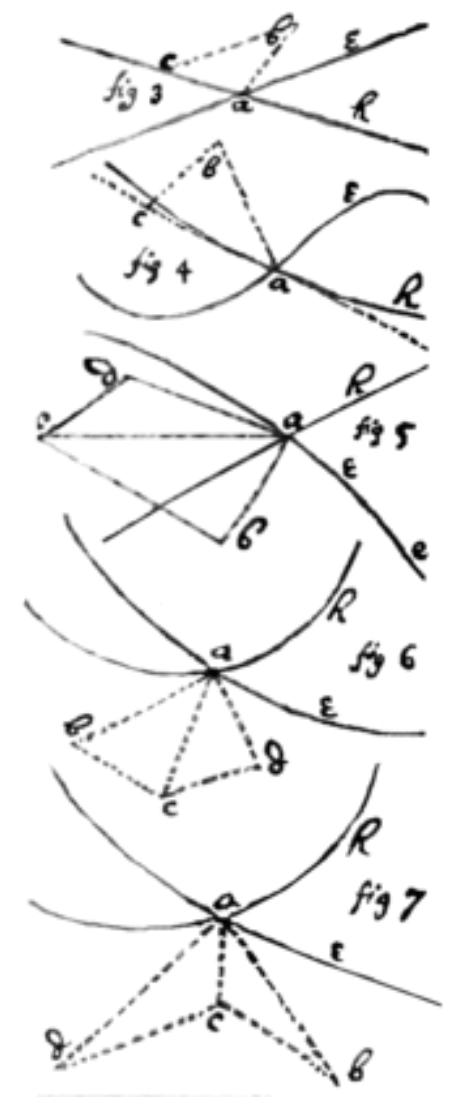

Figura 4: proposição VI. Cada figura corresponde a um movimento possível realizado pelo ponto de intersecção entre duas curvas

Estão sendo considerados cinco movimentos realizados pelo ponto de intersecção de duas curvas. Pode-se dizer que, somente no instante considerado, o ponto de intersecção pertencerá às duas curvas. E, então, a velocidade pontual nesse instante será composta pelas velocidades pontuais das curvas em questão: tomam-se dois segmentos que representem as velocidades pontuais das curvas, mais precisamente o 
componente direcional dessas velocidades. Outros dois segmentos devem representar a componente direcional da velocidade dos pontos em cada curva. Pede-se, então, que se encontre a velocidade pontual do ponto de intersecção. A solução é alcançada através do método do paralelogramo e pela composição geométrica do movimento; ou seja, sem recorrer aos algoritmos provenientes da análise formal.

Entretanto, as soluções das proposições VII e VIII utilizam recursos de outra natureza. Consideremos a proposição VII:

Tendo uma equação que expresse a relação entre duas ou mais linhas, $x, y$, $z$, etc, descritas ao mesmo tempo por dois ou mais corpos em movimento, $A, B$, $C$, etc, a relação de suas velocidades $p, q, r$, etc, poderá ser encontrada desta maneira, isto é: coloque todos os termos de um lado da equação, tornando-os iguais a zero. Primeiro, multiplique cada termo por $\frac{p}{x}$ tantas vezes $x$ tiver dimensões nesse termo. Segundo, multiplique cada termo por $\frac{q}{y}$ tantas vezes $y$ tenha dimensões ali. Terceiro (se existem 3 quantidades desconhecidas), multiplique cada termo por $\frac{r}{z}$ quantas vezes $z$ tenha dimensões nesse termo (e, se existirem ainda mais quantidades desconhecidas, faça o mesmo para todas as quantidades desconhecidas). A soma de todos esses produtos será igual a zero. Essa equação dá a relação das velocidades $p, q$, $r$, etc.

Ou assim: translade todos os termos para um lado da equação e multiplique-os, ordenando-os de acordo $\operatorname{com} x$, por esta expressão:

$$
\text { etc. } \frac{3 p}{x} \cdot \frac{2 p}{x} \cdot \frac{p}{x} \cdot 0 \cdot \frac{-p}{x} \cdot \frac{-2 p}{x} \cdot \frac{-3 p}{x} \cdot \frac{-4 p}{x} \text {.etc ; }
$$

e, sendo ordenada pela dimensão de $y$, multiplique-os por esta:

$$
\text { etc. } \frac{3 q}{y} \cdot \frac{2 q}{y} \cdot \frac{q}{y} \cdot 0 \cdot \frac{-q}{y} \cdot \frac{-2 q}{y} . \text { etc. }
$$

A soma desses produtos será igual a zero, equação esta que dá a relação de suas velocidades $p, q$, etc..”

As velocidades pontuais, nesse caso, não são definidas ou identificadas geometricamente: a relação entre elas é obtida através de uma equação. Esta, por sua vez é resultado de um algoritmo de manipulação dos símbolos (multiplicar por certo termo quantas vezes forem as dimensões, por exemplo).

A prova da proposição introduz, ainda, outro elemento importante: o tempo infinitamente pequeno $o$. Considera-se uma equação algébrica $\mathrm{F}(\mathrm{x}, \mathrm{y})=0$ e um tempo 
infinitamente pequeno $o$ durante o qual os segmentos variáveis $x$ e $y$ tem incrementos infinitamente pequenos po e qo. Segundo Panza (2001) a introdução do tempo $o$ permite interpretar sem nenhuma ambiguidade a razão $\frac{q}{p}$ como uma razão entre segmentos que podem ser tomados como os lados de um triângulo característico. Isso significa que o tratamento dado, na proposição VII, ao problema das velocidades pontuais permite que se utilize os métodos geométricos alcançados até a proposição VI (invariantes geométricos da composição do movimento), sugerindo que a abordagem geométrica poderia ser considerada como um caso particular desse procedimento algorítmico.

Por outro lado, ainda segundo Panza, a noção de velocidade pontual se vincula com o algoritmo sem ser definida formalmente, ou seja, é uma noção intensiva não redutível às grandezas de espaço e tempo, uma ideia que sugere uma inferência demonstrativa, mas que não se define matematicamente: o único objeto matemático associado a ela é uma variável expressa por um símbolo atômico como " $p$ " ou " $q$ ". Essa variável deve ser tratada como qualquer outra, mas não se relaciona com outras mediante a definição explícita de um objeto matemático que pode identificar-se com a velocidade pontual. O único vínculo explícito que a conecta com outras variáveis em jogo é dado pelo algoritmo que resulta da prova. Tal vínculo é suficiente para pôr em movimento um formalismo que de um ponto de vista puramente operativo nos dá a verdadeira e única definição explícita do objeto matemático "velocidade pontual”, mas tal formalismo não resulta de definições prévias.

Portanto, esta solução de problemas geométricos por meio do algoritmo das velocidades pontuais não é somente uma solução de tais problemas aplicáveis apenas em casos particulares. Ela é, também, uma solução que depende intrinsecamente de uma geometria da composição dos movimentos que tem como tarefa fundamental transformar uma ideia vaga de velocidade pontual em um instrumento matemático, 
traduzindo-a em um formalismo geometricamente significativo. Isso não é alcançado por completo no tratado em questão; nem em seu procedimento geométrico (proposições I a VI), nem em seu procedimento algorítmico (proposições VII e VIII).

Esses dois âmbitos matemáticos distintos que surgem no texto do Tratado de 1666 evidenciam a impossibilidade de se estabelecer uma unidade metodológica nesta fase dos estudos matemáticos newtonianos. Embora Newton tenha utilizado sobremaneira os procedimentos analíticos desenvolvidos por Descartes e os tenha, ainda, estendido à solução de outros problemas, tais procedimentos não se mostram suficientes para tratar de um novo elemento com o qual a matemática newtoniana se defronta: o componente cinemático. A noção de velocidade ${ }^{11}$ é a grande responsável pela "dinâmica metodológica" do Tratado: a dificuldade em definir e tratar matematicamente essa noção não é satisfatoriamente resolvida em nenhuma das abordagens.

A geometria da composição do movimento, contida nas primeiras seis proposições, associa as velocidades aos segmentos sem que haja uma definição da noção de velocidade pontual capaz de sustentar essa associação. Em outras palavras, pretende-se esclarecer tal noção usando uma espécie de procedimento recursivo para a determinação das tangentes: parte-se de curvas das quais se conhece a tangente, a reta e o círculo e se supõe que a direção do movimento retilíneo e circular está dada por estas tangentes. Daí se deduz que tais tangentes produzem também a componente direcional da velocidade pontual e se calculam as componentes escalares através de composições e decomposições oportunas acompanhadas de considerações geométricas ligadas à natureza da curva considerada. Os métodos de composição (o do paralelogramo e o anunciado na proposição VI) são assumidos como se fossem justificados por uma noção

\footnotetext{
${ }^{11}$ Newton utiliza, nessa época, o termo "velocidade" para o que será mais tarde chamado de "velocidade pontual" para distingui-la da "velocidade média". Assim como Panza, tomo a liberdade de utilizar o termo "velocidade pontual" para facilitar a compreensão do texto.
} 
metafísica de velocidade pontual. Do mesmo modo, assume-se que a componente direcional da velocidade pontual é dada pela tangente à curva que representa a trajetória do movimento. Já as proposições VII e VIII, totalmente independentes da geometria da composição dos movimentos, buscam um algoritmo para encontrar a velocidade pontual em casos particulares. Portanto, dão lugar a um formalismo alheio à solução dos problemas geométricos e, em alguns casos, se aplica a estes somente depois que uma análise geométrico-cinemática proporciona uma solução independente de tais problemas, ou seja, uma solução de natureza estritamente geométrica, na qual intervêm segmentos desconhecidos que tal formalismo permite calcular.

A relativa independência entre esses dois âmbitos matemáticos permitirá a Newton alcançar o sucesso que se atribui ao De Methodis na resolução dos problemas ali apresentados. O algoritmo desenvolvido na proposição VII expande-se a ponto de tornar-se uma espécie de subteoria independente, puramente algorítmica, que concerne às transformações diretas e inversas introduzidas pelo uso desse algoritmo. Os objetos dessa subteoria são as equações e as variáveis, independentemente de serem consideradas como segmentos. No Tratado de outubro de 1666, Newton desenvolve esta subteoria como um conjunto de métodos de solução para o problema enunciado na proposição VIII (dada a equação das velocidades pontuais, encontrar a equação dos segmentos). Segundo Panza, ele se limita a isso, sem observar que em tal subteoria é irrelevante que se fale de segmentos e de velocidades pontuais de movimentos retilíneos e do movimento retilíneo que gera os segmentos. Porém, no De Methodis, Newton não só estende amplamente tal subteoria, como introduz uma noção que generaliza a noção de segmento gerado por um movimento: a noção de quantidade fluente (à qual está ligada a noção de fluxão por um vínculo análogo com o que liga a velocidade pontual, de um movimento que gera um segmento, com o tal segmento). De maneira tímida, 
Newton apresenta novos objetos que serão objetos da análise. Prefigura-se uma teoria nova e abstrata que se aplica à geometria como uma teoria particular cujos objetos expressam a forma dos objetos da geometria. Essa generalidade será o maior orgulho da análise e uma das razões de seu êxito.

Entretanto, Newton obriga-se a arcar com o ônus da opção pela análise. O formalismo desenvolvido nas proposições VII e VIII deveria aplicar-se, entre outros, a problemas geométricos. Porém, com frequência torna-se difícil a compreensão da relação que liga os resultados da aplicação do formalismo e a solução dos problemas geométricos aos quais se aplica. Como consequência, muitas vezes esta solução é ambígua ou insatisfatória. Esse não é o caso dos problemas diretamente ligados ao problema das tangentes. A geometria da composição dos movimentos é capaz de mostrar esse vínculo com clareza. Essa teoria das tangentes é uma primeira versão daquela espécie de geometria diferencial que Newton empregará nos Principia.

Diante das limitações impostas à matemática newtoniana pela necessidade de resolver problemas de ordem cinemática, Newton avançará tanto em direção à abordagem analítica (De Methodis), quanto em direção à abordagem geométrica (Principia). A noção de velocidade, ou a falta de um fundamento matemático para ela, encontra obstáculos significativos no desenvolvimento do Tratado de 1666. Embora comumente se considere as proposições VII e VIII do Tratado equivalentes aos problemas I e II do De Methodis, a diferença que se percebe nessa reformulação diz respeito justamente à noção de velocidade. O que no primeiro é chamado de "segmento variável descrito por outro segmento" torna-se, no segundo, "quantidade fluente" e o termo problemático ("velocidade”) é substituído por "fluxão". Essa diferença está longe de constituir uma tradução trivial de termos. O modo como o próprio Newton considera 
sua prática matemática é distinto nesses dois escritos e se deixa transparecer no novo "vocabulário". 12

Ainda que o De Methodis tenha alcançado um outro patamar no que diz respeito à solução dos problemas que envolvem cinemática, as dificuldades, no tratamento geométrico de tais problemas, suscitaram questões relevantes como, por exemplo, a da composição do contínuo. Nesse sentido, há, certamente, um debate entre os comentadores acerca da influência de Barrow no trabalho de Newton. Independentemente disso, pode-se assumir, seguramente, que esses dois autores compartilharam o que se chama de representação cinemática das grandezas geométricas. Barrow depara-se com o problema de explicar a composição do contínuo por indivisíveis ${ }^{13}$. Resumidamente, trata-se de saber de que modo a composição de "grandezas" menores que qualquer grandeza dada pode formar uma grandeza geométrica contínua como, por exemplo, uma linha. Tal questão desemboca em importantes problemas que rodeavam a matemática da época. Basta lembrar do paradoxo de Zenão e de suas diversas variações.

Nesse contexto, a representação cinemática é um recurso capaz de contornar esses problemas ao introduzir na geometria a dimensão do tempo. O tempo de que se trata aqui é um tempo geométrico, um recurso da mente que confere um caráter fluente às entidades geométricas. Assim, a linha deixa de ser considerada como um agregado dos seus pontos para ser tratada como um rastro, ou traçado, de um ponto que se desloca no espaço. Do mesmo modo, o plano é o resultado do movimento da linha e o sólido, do movimento do plano. Esse recurso, no entanto, não está livre de dificuldades. Segundo uma concepção clássica, razões são relações abstratas e quantidades são

\footnotetext{
${ }^{12}$ O uso do termo "fluxão" no De Methodis e suas implicações para a questão desta pesquisa serão alvo do capítulo 4.

${ }^{13}$ Não há, de fato, nenhuma evidência de que Newton, em seus primeiros manuscritos, tenha feito a mesma opção de Barrow pelo caráter indivisível do infinitamente pequeno.
} 
necessariamente coisas concretas. Portanto, razões não podem ser quantidades. Tal concepção é inteiramente assumida por Barrow. Põe-se, então, o problema de determinar a quantidade da velocidade. Ela é uma relação entre o tempo, considerado como uma noção apenas imaginável, e o espaço, tangível aos sentidos.

Newton esquiva-se desse problema assumindo que a expressão da curva pela equação faz com que as razões entre as quantidades estejam realmente implicadas na curva. Além disso, ele não considera o tempo apenas como um recurso para a geração de figuras. Ao contrário, ele assume o tempo e o espaço eles mesmos. Mostra-se, então, que o esquema cinemático de Barrow é assumido por Newton de uma maneira muito mais literal. Newton fornece a esse esquema uma reinterpretação ontológica. Se, para Barrow, o movimento é um método abstrato responsável pela geração de figuras na geometria, para Newton essa é a maneira real como as quantidades são geradas. Num tratado, De quadratura curvarum, escrito alguns anos mais tarde (1693; publicado integralmente apenas em 1704), Newton exprime de maneira clara suas divergências com o enfoque de Barrow:

Eu não considero quantidades matemáticas como constituídas de indivisíveis, seja de qualquer maneira, partes possíveis ou partes infinitamente pequenas, mas como descritas por um movimento contínuo. Linhas são descritas, e por descrição são geradas, não por uma justaposição de partes, mas pelo movimento contínuo dos pontos, planos pelo movimento de linhas, sólidos pelo movimento de planos, ângulos pela rotação dos seus lados, tempo por um fluxo contínuo, e assim por diante. Essa geração é fundamentada na Natureza, e todo dia decretada nos movimentos dos corpos, e exibida diante dos nossos olhos. (Newton. MP. 1967-1981. V.1, p. 106-107).

Assumindo a geração das figuras no tempo fluente, Newton pôde abrir mão da noção de tal grandeza infinitamente pequena, indivisível ou não, em proveito do conceito de limite. Ao invés de considerar uma porção infinitamente pequena da figura, tomam-se as razões entre as quantidades nascentes ou evanescentes no tempo que flui continuamente. A seção I do Livro I dos Principia trata justamente do método das primeiras e últimas razões de quantidades. A fim de ilustrar esse método, sem recorrer a 
uma série exaustiva de demonstrações, basta considerar o primeiro lema dessa seção. $\mathrm{O}$ enunciado do Lema I é o seguinte: "As quantidades e as razões de quantidades, que em qualquer tempo finito convergem continuamente para a igualdade, e antes do fim daquele tempo aproximam-se mais uma da outra do que por qualquer diferença dada, tornam-se finalmente iguais" (Newton, 1999[1687], p.433). Pode-se entender a expressão "antes do fim daquele tempo" como a última parcela infinitamente pequena desse intervalo de tempo finito que está sendo considerado. Considerar que o espaço possui tal grandeza infinitamente pequena gera, como mostrado acima, problemas relacionados ao contínuo. Porém, o tempo, embora também seja contínuo, permite que se considere uma parcela infinitamente pequena sua, em virtude do seu caráter fluente.

Descrito desse modo, o percurso matemático realizado por Newton parece ser guiado prioritariamente pela maior capacidade de cada opção em resolver os problemas; ou, assunto recorrente nesse capítulo, pela maior generalidade potencialmente alcançada por tal opção. Assim, abordagem analítica e abordagem geométrica se revezam como opções viáveis, porém, nem sempre autônomas. Entretanto, a eficácia na solução dos problemas (objetivo principal de qualquer matemático) não é o único critério utilizado por Newton ao abandonar ou aderir a determinada via. O comprometimento do autor com concepções ontologicamente mais consistentes dos objetos matemáticos deve mostrar-se de maneira mais contundente em uma etapa mais madura de sua obra ${ }^{14}$. A questão de saber em que medida esse comprometimento conduz os procedimentos matemáticos de Newton, tratada simplificadamente como a questão do realismo matemático newtoniano, está intimamente ligada à dinâmica e à articulação entre a abordagem analítica e a abordagem geométrica na obra matemática newtoniana, considerada em sua totalidade.

\footnotetext{
${ }^{14}$ Embora possamos encontrar sinais de tal comprometimento já no período inicial.
} 


\subsection{De Methodis: as operações fundamentais}

Newton inicia o texto do De Methodis explicando as razões que o levaram a escrevê-lo. Primeiramente, ele observa que os geômetras de sua época negligenciam o método sintético dos antigos e aplicam-se ao cultivo da análise. Com a ajuda desse método (o método de análise), eles superaram inúmeras dificuldades restando, porém, o problema da quadratura das curvas e outros tópicos semelhantes a serem resolvidos. Então, o propósito do De Methodis é justamente o de ampliar os limites do campo da análise, estendendo-o à doutrina das curvas. Tal ampliação começa pela tarefa de expor, em termos de séries, as principais operações matemáticas.

Newton afirma que exceto por Mercator $^{15}$, as operações foram até então comumente consideradas muito similares quer aplicadas aos números, quer às variáveis. Isso, porém, não se aplica quando as quantidades são definidas para os números e indefinidas para as variáveis. Então, o que ele propõe é um modo de conformar às variáveis a doutrina dos números decimais. Com esse propósito, ele inicia estabelecendo uma comparação entre a doutrina das espécies e a doutrina dos números, afirmando que a primeira relaciona-se com a Álgebra da mesma maneira que a segunda está ligada Aritmética. Assim, operações de adição, subtração, multiplicação, divisão e extração de raízes seriam aprendidas por um estudante hábil em Aritmética decimal e Álgebra vulgar. Esse estudante, observando a correspondência que se têm entre frações decimais e termos algébricos infinitamente contínuos, constata que conforme as operações com números decimais, posições dispostas à direita diminuem continuamente na proporção decimal. Disso se conclui que, nas operações com variáveis, quando os termos são

\footnotetext{
${ }^{15}$ Newton refere-se à obra Logarithmotecnia (1668) de Nicolaus Mercator, proposição XVII referente à quadratura da hipérbole.
} 
dispostos em progressões uniformes continuadas infinitamente, eles diminuem na proporção, de acordo com a ordem das dimensões, por conveniência de qualquer numerador ou denominador.

Ao considerar a natureza dos decimais, vê-se que eles podem ser reduzidos a frações e por isso, em certa medida, possuem a mesma natureza de integrais. Com base em tal semelhança, Newton passa a manipular as variáveis envolvidas como integrais. E, por conveniência, todas as séries infinitas em operações com variáveis e todos os termos complicados, como frações cujos denominadores são quantidades compostas ou raízes de quantidades compostas (ou equações afetadas), podem ser reduzidos a classes de quantidades simples cujos numeradores e denominadores são simples.

Tendo introduzido essa noção de redução de quantidades compostas a quantidades simples - cuja remissão ao método cartesiano parece imediata - Newton enuncia o programa previsto para o De Methodis. Primeiramente, ele pretende mostrar como são realizadas essas reduções de quantidades compostas em termos simples e, em seguida, pretende aplicar esse procedimento na solução de problemas.

\subsubsection{Exemplos de redução por divisão}

Propõe-se a fração $\frac{a^{2}}{b+x}$. Assim, divide-se $a^{2}$ por $b+x$ do seguinte modo.

$$
\begin{aligned}
& \text { divisor dividendo quociente } \\
& b+x) \quad a^{2}+0 \quad\left(\frac{a^{2}}{b}-\frac{a^{2} x}{b^{2}}+\frac{a^{2} x^{2}}{b^{3}}-\frac{a^{2} x^{3}}{b^{4}}+\frac{a^{2} x^{4}}{b^{5}} \cdots\right. \\
& \ominus \quad a^{2}+\frac{a^{2} x}{b^{2}} \\
& -\frac{a^{2} x}{b^{2}}+0 \\
& \ominus-\frac{a^{2} x}{b^{2}}-\frac{a^{2} x^{2}}{b^{2}}
\end{aligned}
$$




$$
\begin{array}{r}
\ominus \frac{a^{2} x^{2}}{b^{2}}+\frac{0}{b^{2}}+\frac{a^{2} x^{3}}{b^{3}} \\
\qquad \frac{-\frac{a^{2} x^{3}}{b^{3}}}{-\frac{a^{2} x^{3}}{b^{3}}-\frac{a^{2} x^{4}}{b^{4}}} \\
\frac{a^{2} x^{4}}{b^{4}}
\end{array}
$$

0 . Tome o quociente mais simples e esse será o $1^{\circ}$ termo da série: $\frac{a^{2}}{b}$

1. Multiplique o $1^{\circ}$ termo pelo divisor

$\frac{a^{2}}{b} \cdot(b+x)=a^{2}+\frac{a^{2} x}{b}$

1.1 Subtraia do dividendo o resultado acima

1.2 Tome o resto e divida-o por $b$

$$
\left(-\frac{a^{2} x}{b}\right) \div b=-\frac{a^{2} x}{b^{2}}
$$

2. Multiplique o $2^{\circ}$ termo pelo divisor

$$
\left(-\frac{a^{2} x}{b^{2}}\right) \cdot(b+x)=-\frac{a^{2} x}{b}-\frac{a^{2} x^{2}}{b^{2}}
$$

2.1 Subtraia do dividendo o resultado acima

2.2 Tome o resto e divida-o por $b$

3. Multiplique o $3^{\circ}$ termo pelo divisor

$\frac{a^{2} x^{2}}{b^{3}} \cdot(b+x)=\frac{a^{2} x^{2}}{b^{2}}+\frac{a^{2} x^{3}}{b^{3}}$

3.1 Subtraia do dividendo o resultado acima

3.2 Tome o resto e divida-o por $b$

4. Multiplique o $4^{\mathrm{o}}$ termo pelo divisor

$\left(-\frac{a^{2} x^{3}}{b^{4}}\right) \cdot(b+x)=-\frac{a^{2} x^{3}}{b^{3}}-\frac{a^{2} x^{4}}{b^{4}}$

4.1 Subtraia do dividendo o resultado acima

4.2 Tome o resto e divida-o por $b$ 
Produz-se, então, a série $\frac{a^{2}}{b}-\frac{a^{2} x}{b^{2}}+\frac{a^{2} x^{2}}{b^{3}}-\frac{a^{2} x^{3}}{b^{4}} \cdots$ que continua ad infinitum e é equivalente a $\frac{a^{2}}{b+x}$. Ou, ao estabelecer $x$ como o primeiro termo do divisor, desta maneira tem-se:

$$
x+b) a^{2}\left(\text { produzirá } \frac{a^{2}}{x}-\frac{a^{2} b}{x^{2}}+\frac{a^{2} b^{2}}{x^{3}}-\frac{a^{2} b^{3}}{x^{4}} \cdots\right.
$$

, da mesma maneira, a fração $\frac{1}{1+x^{2}}$ é reduzida a

$$
1-x^{2}+x^{4}-x^{6}+x^{8} \cdots \text { ou }\left[\text { para } \frac{1}{x^{2}+1},\right] x^{-2}-x^{-4}+x^{-6}-x^{-8} \ldots
$$

E, a fração $\frac{2 x^{\frac{1}{2}}-x^{\frac{3}{2}}}{1+x^{\frac{1}{2}}-3 x}$ [é reduzida] para $2 x^{\frac{1}{2}}-2 x+7 x^{\frac{3}{2}}-13 x^{2}+34 x^{\frac{5}{2}} \ldots$

Em seguida, Newton estabelece algumas propriedades de potências. Aqui, a propósito, deve-se notar que Newton empregou $x^{-1}, x^{-2}, x^{-3}, x^{-4}, \ldots$ no lugar de $\frac{1}{x}, \frac{1}{x^{2}}, \frac{1}{x^{3}}$ $, \frac{1}{x^{4}}, \ldots$; e $x^{\frac{1}{2}}, x^{\frac{3}{2}}, x^{\frac{5}{2}}, x^{\frac{1}{3}}, x^{\frac{2}{3}}, \ldots$, no lugar de $\sqrt{x}, \sqrt{x^{3}}, \sqrt{x^{5}}, \sqrt[3]{x}, \sqrt[3]{x^{2}}, \ldots$, e $x^{-\frac{1}{2}}$ $x^{-\frac{3}{2}}, x^{-\frac{1}{4}}$, no lugar de $\frac{1}{\sqrt{2}}, \frac{1}{\sqrt[3]{x^{2}}}, \frac{1}{\sqrt[4]{x}}, \ldots$ Essa similaridade da forma pode ser, deste modo, melhor detectada mediante progressões geométricas, $x^{3}, x^{\frac{5}{2}}, x^{2}, x^{\frac{3}{2}}, x, x^{\frac{1}{2}}, x^{0}$ (ou 1$), x^{-\frac{1}{2}}, x^{-1}, x^{-\frac{3}{2}}, x^{-2}, \ldots$

Dessa forma, a série $\frac{a^{2}}{x}-\frac{a^{2} b}{x^{2}}+\frac{a^{2} b^{2}}{x^{3}} \cdots$ pode ser escrita como $a^{2} x^{-1}-$ $a^{2} b x^{-2}+a^{2} b^{2} x^{-3} \ldots \mathrm{E} \sqrt{a^{2}-x^{2}}$ pode ser escrito como $\left(a^{2}-x^{2}\right)^{\frac{1}{2}}$; e, $\left(a^{2}-x^{2}\right)^{2}$ no lugar do quadrado de $\left(a^{2}-x^{2}\right)$; e $\left(\frac{a b^{2}-y^{3}}{b y+y^{2}}\right)^{\frac{1}{2}}$ no lugar de $\sqrt{\frac{a b^{2}-y^{3}}{b y+y^{2}}}$. E da mesma forma para outros casos. Na sequência, será justificada a distinção de potências como positivas, negativas, integrais e fracionadas. 
2.1.2 Exemplos de redução por extração de raiz

Quando a quantidade $a^{2}+x^{2}$ é proposta, a raiz será extraída da seguinte maneira:

radicando

$$
a^{2}+x^{2} \quad\left(a+\frac{x^{2}}{2 a}-\frac{x^{4}}{8 a^{3}}+\frac{x^{6}}{16 a^{5}}-\frac{5 x^{8}}{128 a^{7}}+\frac{7 x^{10}}{256 a^{9}}-\frac{21 x^{12}}{1024 a^{11}} \cdots\right.
$$

$\ominus a^{2}$

$$
\begin{gathered}
\ominus x^{2}+\frac{x^{4}}{4 a^{2}} \\
\ominus \frac{-\frac{x^{4}}{4 a^{2}}}{-\frac{x^{4}}{4 a^{2}}-\frac{x^{6}}{8 a^{4}}+\frac{x^{8}}{64 a^{6}}} \\
\ominus \frac{\frac{x^{6}}{8 a^{4}}-\frac{x^{8}}{64 a^{6}}}{8 a^{4}}+\frac{x^{8}}{16 a^{6}}-\frac{x^{10}}{64 a^{8}}+\frac{x^{12}}{256 a^{10}} \\
\frac{x^{6}}{64 a^{6}}-\frac{x^{10}}{64 a^{8}}+\frac{x^{12}}{256 a^{10}}
\end{gathered}
$$

0 . Tome a raiz mais simples e essa será o $1^{\circ}$ termo da série: $a$

1. Subtraia do radicando o $1^{\circ}$ termo ao quadrado: $a^{2}$

1.1 Dobre o $1^{\circ}$ termo: $2(a)=2 a$

1.2 Divida o resto pelo resultado acima:

$x^{2} \div 2 a=\frac{x^{2}}{2 a}$

$1.3 \mathrm{O}$ resultado é o $2^{\circ}$ termo da série.

2. Dobre o $1^{\circ}$ termo e some ao $2^{\circ}: 2(a)+\frac{x^{2}}{2 a}=2 a+\frac{x^{2}}{2 a}$

2.1 Multiplique o resultado acima pelo $2^{\circ}$ termo:

$$
\left(2 a+\frac{x^{2}}{2 a}\right) \cdot \frac{x^{2}}{2 a}=x^{2}+\frac{x^{4}}{4 a^{2}}
$$


2.2 Subtraia o resultado acima do resto

2.3 Divida o resto pelo dobro do $1^{\circ}$ termo:

$\left(-\frac{x^{4}}{4 a^{2}}\right) \div 2 a=-\frac{x^{4}}{8 a^{3}}$

$2.4 \mathrm{O}$ resultado acima é $3^{\circ}$ termo

3. Dobre o $1^{\circ}$ e $2^{\circ}$ termos e some ao $3^{\circ}$ :

$2\left(a+\frac{x^{2}}{2 a}\right)+\left(-\frac{x^{4}}{8 a^{3}}\right)=2 a+\frac{x^{2}}{a}-\frac{x^{4}}{8 a^{3}}$

3.1 Multiplique o resultado pelo $3^{\circ}$ termo:

$\left(2 a+\frac{x^{2}}{a}-\frac{x^{4}}{8 a^{3}}\right) \cdot\left(-\frac{x^{4}}{8 a^{3}}\right)=-\frac{x^{4}}{4 a^{2}}-\frac{x^{6}}{8 a^{4}}+\frac{x^{8}}{64 a^{6}}$

3.2 Subtraia o resultado acima do resto

3.3 Divida o resto pelo dobro do $1^{\circ}$ termo:

$\left(\frac{x^{6}}{8 a^{4}}-\frac{x^{8}}{64 a^{6}}\right) \div 2 a=\frac{x^{6}}{16 a^{5}}-\frac{x^{8}}{128 a^{7}}$

3.4 A primeira fração do resultado acima é o $4^{\circ}$ termo

4. Dobre o $1^{\circ}, 2^{\circ}$ e $3^{\circ}$ termos e some ao $4^{\circ}$ termo:

$2\left(a+\frac{x^{2}}{2 a}-\frac{x^{4}}{8 a^{3}}\right)+\frac{x^{6}}{16 a^{5}}=2 a+\frac{x^{2}}{a}-\frac{x^{4}}{4 a^{3}}+\frac{x^{6}}{16 a^{5}}$

4.1 Multiplique o resultado pelo $4^{\mathrm{o}}$ termo:

$\left(2 a+\frac{x^{2}}{a}-\frac{x^{4}}{4 a^{3}}+\frac{x^{6}}{16 a^{5}}\right) \cdot\left(\frac{x^{6}}{16 a^{5}}\right)=\frac{x^{6}}{8 a^{4}}+\frac{x^{8}}{16 a^{6}}-\frac{x^{10}}{64 a^{8}}+\frac{x^{12}}{256 a^{10}}$

4.2 Subtraia o resultado acima do resto

4.3 Divida o resto pelo dobro do $1^{\circ}$ termo:

$\left(-\frac{5 x^{8}}{64 a^{6}}+\frac{x^{10}}{64 a^{8}}-\frac{x^{12}}{256 a^{10}}\right) \div 2 a=-\frac{5 x^{8}}{128 a^{7}}+\frac{x^{10}}{128 a^{9}}-\frac{x^{12}}{512 a^{11}}$

4.4 A primeira fração do resultado acima é o $5^{\circ}$ termo

E, assim, como resultado tem-se $a+\frac{x^{2}}{2 a}-\frac{x^{4}}{8 a^{3}} \cdots$ Note que Newton suprimiu os termos cujas dimensões foram superiores ao último termo apresentado da série, ou seja múltiplo de $\frac{x^{12}}{a^{11}}$, pois foi até onde Newton quis estender a série. 
Mas, na prática, não é raro que essas operações possam ser preparadas apropriadamente. Como no exemplo a seguir, para extrair $\sqrt{\frac{1+a x^{2}}{1-b x^{2}}}$, o numerador e o denominador não deveriam estar na mesma forma, logo multiplicam-se ambos por $\sqrt{1-b x^{2}}$, resultando em $\frac{\sqrt{1+(a-b) x^{2}-a b x^{4}}}{1-b x^{2}}$ e, o restante do trabalho, então, será terminado pela mera extração da raiz do numerador dividida pelo denominador.

Dessas observações, fica claro como outros tipos de raízes podem ser extraídas e como qualquer quantidade pode ser composta. Contudo, pode ocorrer um “emaranhamento" com raízes e denominadores, como este,

$$
\left.x^{3}+\frac{\sqrt{x-\sqrt{1-x^{2}}}}{\sqrt[3]{a x^{2}+x^{3}}}-\frac{\sqrt[5]{x^{3}-2 x^{5}-x^{\frac{3}{2}}}}{\sqrt[3]{x+x^{2}}-\sqrt{2 x-x^{\frac{2}{3}}}}\right)
$$

que pode ser reduzido a uma série infinita de termos simples.

\subsection{De Methodis: os problemas I e II}

Trataremos aqui dos problemas I e II do tratado De Methodis Serierum et Fluxionum, visto que o próprio Newton os escolhe como "ilustração dessa arte analítica”. Trata-se de dois problemas que se complementam na medida em que um é o inverso do outro. O primeiro pede a velocidade, em um movimento contínuo, tendo sido dado o espaço percorrido; e o segundo pede o espaço percorrido, em um movimento contínuo, tendo sido dada a velocidade. É introduzida, então, uma concepção fundamental para o desenvolvimento do método das fluxões: as quantidades (espaço percorrido, velocidade) são geradas pelo movimento. Ou seja, a matemática do $D e$ Methodis é, essencialmente, cinemática. Entretanto, essa associação entre a quantidade e o movimento que a teria produzido não é inédita. Desde Arquimedes, passando por 
Oresme $^{16}$ (séc. XIV), o movimento de um ponto é associado a alguma quantidade cinemática. Porém, é somente no século XVII, com Galileu, Torricelli e Roberval, que o movimento é considerado no estudo das curvas, em especial no problema das tangentes, mencionado anteriormente.

Como posto na seção anterior, antes mesmo do De Methodis, Newton associa o estudo das curvas a esses dois problemas chamados "problemas fundamentais" (problemas I e II do De Methodis). A novidade que se impõe nesse tratado, é que, agora, ele o faz a partir da equação da curva (e não mais pela pura descrição geométrica, como no Tratado de 1666), considerando as duas variáveis em questão como dotadas de movimento. Por essa razão, diz-se que o De Methodis concentra a apresentação analítica do método das fluxões de Newton, e a comparação com a solução geométrica, anterior a ele, pode nos fornecer importantes elementos de estudo do período inicial da matemática newtoniana. A principal diferença dessa "nova apresentação" reside no fato de que, com a utilização da equação da curva, torna-se dispensável a descrição geométrica particular para cada caso considerado. Dizer que o tratamento dado ao problema é analítico significa afirmar, antes de tudo, sua generalidade. A escolha desses dois problemas, como exemplo paradigmático da apresentação analítica do método das fluxões, justifica-se, também, porque tal generalidade estende-se para além de suas soluções. Seu desenvolvimento apresenta um procedimento algorítmico que Newton aplica, a seguir, a inúmeros outros problemas. ${ }^{17}$ Em outras palavras, se é possível falar em um método das fluxões, o desenvolvimento dos dois primeiros problemas do $D e$ Methodis concentra seu cerne. Newton resume do seguinte modo a apresentação de tais problemas:

\footnotetext{
${ }^{16}$ Nicole Oresme parece ter sido o primeiro a utilizar um referencial (tempo na abcissa e velocidade na ordenada) para descrever o movimento uniformemente acelerado.

${ }^{17}$ Entre esses problemas destacam-se: o problema de determinar a quadratura da curva e problemas relativos a tangentes, raios, subnormais, máximos e mínimos, etc.
} 
Para uma ilustração da arte analítica, apresento algumas espécies de problemas, especialmente os proporcionados pela natureza das curvas. Agora, em função disso, observo que todas as dificuldades a esse respeito podem ser reduzidas somente a dois problemas, considerando o espaço como descrito pelo movimento local. (Newton, MPIII, p.71).

Ao afirmar que o "espaço é descrito pelo movimento local", movimento no espaço, Newton pressupõe que as quantidades recebem acréscimo (se o movimento é acelerado) ou decréscimo (se é retardado) contínuo quando são geradas: um ponto em movimento descreve uma linha e linhas em movimento descrevem planos. Na concepção cinemática newtoniana, o aumento ou diminuição das magnitudes ocorrem no tempo e, é claro, possuem alguma velocidade. Porém, tais grandezas apresentam uma distinção importante. O tempo, tomado formalmente, que flui ininterrupta e uniformemente, é um e o mesmo para todos os movimentos, ainda que suas velocidades sejam distintas. Isso garante que se possam comparar os diversos movimentos, atribuindo a cada um sua velocidade ou, em outras palavras, mensurando a intensidade com que cada quantidade aumenta ou diminui. Ou seja, a velocidade não pode ser medida diretamente ${ }^{18}$, como nas magnitudes extensivas, mas, como magnitude intensiva, sua mensuração se dá exclusivamente através das magnitudes extensivas: o espaço, por exemplo ${ }^{19}$.

O tempo, assim como a velocidade, não pode ser medido diretamente ${ }^{20}$ : “...não consideramos o tempo aqui algo além do que é exposto e medido por um movimento local uniforme..." (MW-1, p. 49). Isso quer dizer que, a fim de submetê-lo à equação, Newton não está considerando o tempo formalmente, como na consagrada noção newtoniana de tempo absoluto. Essa analogia com o movimento local uniforme, ou seja,

\footnotetext{
${ }^{18}$ Essa concepção de velocidade já estava presente em Galileu

${ }^{19}$ Obviamente, o espaço é prontamente admitido como uma magnitude extensiva.

${ }^{20}$ Isso se aplica ao tempo assim como e entendido no De Methodis. Porém, no De Gravitatione, o tempo é tratado como uma grandeza extensiva, assim como o espaço (noção de tempo e espaço absolutos).
} 
que flui uniformemente, consiste em uma medida indireta do tempo, a partir do movimento local:

(...) ao passo que (...) somente coisas da mesma espécie podem ser comparadas, sendo que vale o mesmo para suas velocidades de aumento e decréscimo. Por isso, no que segue, não tratarei o tempo considerando-o formalmente. Mas suporei que alguma das quantidades propostas, sendo da mesma espécie, é incrementada por um fluxo uniforme, pelo qual o restante poderia referir-se como se fosse ao tempo. Sendo por isso, por meio da analogia, que isso pode propriamente receber o nome de tempo. Seja onde for que a palavra tempo ocorrerá no que segue (que em consideração à perspicuidade e distinção que tenho algumas vezes usado), não terei compreendido como se medisse o tempo em sua acepção formal, mas somente compreendo esta outra quantidade, por cujo aumento uniforme ou fluxão, o tempo é exposto e medido (MW1, p. 49).

Entretanto, essa concepção permite o tratamento do tempo como uma quantidade extensiva, já que todo movimento local ocorre no "tempo verdadeiro" e, por analogia, o tempo será incluído nas equações como uma quantidade que, mesmo não sendo esse "tempo verdadeiro", faz referência a ele.

Tendo esclarecido de que modo espaço, velocidade e tempo são compreendidos no De Methodis, podem ser introduzidos os três conceitos centrais da concepção cinemática aqui considerada: quantidade fluente, fluxão e momento. Tais conceitos estão claramente relacionados aos primeiros; não, entretanto, de maneira recíproca e direta.

Newton chama de quantidade fluente aquela quantidade gerada, ou descrita pelo movimento. Ou seja, a linha descrita pelo movimento do ponto, o plano descrito pelo movimento da linha ou o sólido descrito pelo movimento do plano. Os símbolos utilizados nas equações para tais quantidades são as letras finais do alfabeto: $v, x, y$ e $z$. A velocidade com a qual esse movimento é descrito é chamada de fluxão e representada por letras pontuadas: "a velocidade pela qual todo fluente é aumentado pelo seu movimento gerador (que eu chamarei de Fluxão, ou simplesmente velocidade ou celeridade) representarei pelas mesmas letras [que as das quantidades fluentes] pontuadas assim: $\dot{v}, \dot{x}, \dot{y}$ e $\dot{z} . ”(M W-1$, p. 49). Assim, as quantidades fluentes 
representadas pelas letras $v$ e $x$ possuem suas fluxões representadas, respectivamente, pelas letras pontuadas $\dot{v}$ e $\dot{x}$.

Por fim, os momentos de quantidades fluentes são partes indefinidamente pequenas dessas quantidades, aumentadas em uma "porção indefinidamente pequena de tempo". Ou seja, toma-se a menor parte fluente, por analogia, do "tempo verdadeiro", a fim de obter-se a menor parte dessa quantidade fluente. O modo como os momentos são representados nas equações pode esclarecer sua articulação com a noção de tempo. Quando duas quantidades fluentes são representadas por $x$ e $y$, os seus momentos entrarão nas equações como $\dot{x} O$ e $\dot{y} O$, onde a fluxão é multiplicada por $O$ (a letra grega ômicron), que marca a presença do tempo. Novamente, não é o tempo considerado formalmente, mas apenas um recurso à parcela indefinidamente pequena de tempo que permitiria que se tomasse uma porção indefinidamente pequena da linha. Assim, os momentos são representados pela fluxão da quantidade fluente, multiplicada pelo

marcador de tempo. Isso quer dizer que, se pensarmos a fluxão como análoga à velocidade, ao multiplica-la pelo tempo, obteríamos o espaço percorrido. Então, o momento pode ser acrescentado à quantidade fluente (magnitude espacial) significando o aumento que essa quantidade sofreu naquela parcela indefinidamente pequena de tempo $(x+\dot{x} o)$.

\subsubsection{O Problema I}

Como dito acima, trata-se de encontrar a velocidade do movimento em algum tempo determinado, tendo sido dado o comprimento do espaço descrito continuamente. Ora, o espaço descrito é dado através da equação da curva. Por exemplo: 
Isso é o mesmo que afirmar que a equação da curva é a equação da quantidade fluente. Assim, a solução está na transformação da equação da quantidade fluente em uma equação que forneça as velocidades, ou fluxões; o que somente é possível através da noção de momento e utilizando as somas $(x+\dot{x} o) \mathrm{e}(y+\dot{y} o)$. Partindo de tais bases, a solução se desenvolve através da manipulação algébrica dos símbolos em questão. A equação (2.1) expressa a relação entre as quantidades fluentes $x$ e $y$. As manipulações acima mencionadas transformarão essa equação em 2.2). Esse é o primeiro de cinco exemplos de equações que Newton utiliza no Problema I.

Os passos para a solução são os seguintes: (i) organizar a equação de acordo com as potências das quantidades fluentes; (ii) multiplicar cada termo por uma progressão geométrica; (iii) aplicar os dois primeiros passos para todos os símbolos de quantidade fluentes da equação e, por fim, (iv) somar todos os resultados das multiplicações às equações. Ainda no primeiro exemplo, Newton apresenta o seguinte quadro como parte da solução:

\begin{tabular}{|c|c|}
\hline Multiplicar $x^{3}-a^{2}+a x y$ & $\rightarrow y^{3} \operatorname{taxyz}$ \\
\hline Por $\frac{3 \dot{x}}{x} \cdot \frac{2 \dot{x}}{x} \cdot \frac{\dot{x}}{x} \cdot \mathrm{O}$ & $\frac{3 \dot{y}}{y} \cdot \frac{\dot{y}}{y} \cdot 0$ \\
\hline Tem-se: $3 x^{2}-2 a^{2}+a i n *$ & $-3 y y^{2}+a x x *$ \\
\hline
\end{tabular}

Vê-se que o passo (i) já está cumprido na apresentação inicial da equação, pois suas potências já apresentam uma ordem decrescente. Partindo de tais potências, é construída 
uma série aritmética na qual o valor da potência é multiplicado pelo símbolo da fluxão e dividido por $x$. O segundo passo é realizado na série:

$$
\underset{x}{3 x} \frac{2 x}{x} \frac{i x}{x} C
$$

onde o último valor corresponde à potência de $x$ multiplicada por $y^{3}$, isto é, $x^{0} y^{3}$. O resultado da equação, multiplicando cada membro pelo seu respectivo valor na série, será $^{21}$ :

\section{$3 x^{2}-2 x^{2}+10 \pi$.}

O terceiro passo prevê que se faça o mesmo com respeito à quantidade fluente $y$. Assim, tem-se:

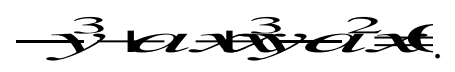

A progressão aritmética para multiplicação dos membros dessa equação é:

$$
\frac{3 \dot{y}}{y}, \frac{\dot{y}}{y}, 0
$$

Ao multiplicá-los, o resultado será:

$$
-3 y y^{2}+a j x
$$

O último passo pede que se faça a soma entre as equações resultantes, ou seja, entre

$$
\left(3 x^{2}-2 x^{2}+10 i x\right) \text { e }\left(-3 y y^{2}+a y x\right) \text {. }
$$

Portanto, o resultado será uma equação que expressa a relação entre as fluxões $\dot{x}_{\mathrm{e}} \dot{y}$, ou seja:

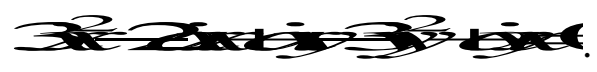

\footnotetext{
${ }^{21}$ Por exemplo, o primeiro valor dessa equação $3 \dot{x} x^{2}$ é resultado da multiplicação entre $x^{3}$ e $\frac{3 \dot{x}}{x}$.
} 
Chega-se, assim, ao que foi pedido. Entretanto, Newton realiza uma etapa complementar à solução, percorrendo o mesmo caminho por outra via algébrica. Ou seja, parte da equação inicial para chegar à equação solução, com o propósito de demonstrar (justificar) a solução, recorrendo, inicialmente, ao conceito de momento. A possibilidade de realizar as somas $(x+\dot{x} o)_{\mathrm{e}}(y+\dot{y} o)$ permitem que Newton interprete a equação ${ }^{3} x^{3}=(2.1)$ como a relação entre as quantidades fluentes $x \mathrm{e}$ $y$, nascentes e finitas. Em termos cinemáticos, tais quantidades finitas são aumentadas pelo acréscimo de seus momentos, ou seja, substitui-se $x$ e $y$ por $(x+\dot{x} o)_{\mathrm{e}}(y+\dot{y} o)$, respectivamente, o que resulta em:

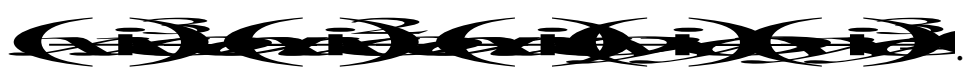

E, fazendo as multiplicações necessárias, obtém-se:

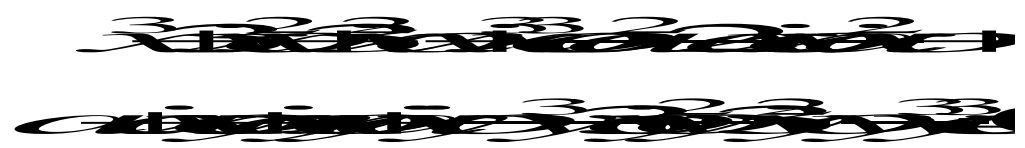

Considerando que a equação inicial está igualada a zero, Newton anula, em (2.3), todos os termos de (2.1):

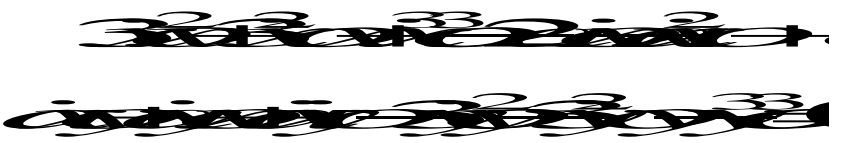

Visto que, em (2.4), todos os termos estão multiplicados por ${ }^{o}$, tal elemento comum pode ser eliminado, chegando-se a: 
Finalmente, Newton trata os termos multiplicados por ${ }^{O}$ que ainda restaram como quantidades infinitamente pequenas, já que o próprio $O$ é uma quantidade infinitamente pequena e, multiplicando quantidades finitas, as anularia. Chega-se, assim, à mesma equação-solução encontrada na etapa anterior.

\subsubsection{O Problema II}

O Problema II, como já foi dito, consiste no inverso do anterior, ou seja, a velocidade do movimento sendo continuamente dada, encontrar o comprimento do espaço descrito em algum tempo proposto. Nos termos aqui considerados, consiste em buscar a equação de relação entre fluentes partindo da equação que expressa a relação entre as suas fluxões. Esse é o ponto de partida para a solução proposta por Newton que, é claro, consiste em manipular as equações envolvendo fluxões para obter as equações entre as quantidades fluentes correspondentes. Esse procedimento é o caminho inverso daquele realizado na solução do primeiro problema:

Como este problema é o inverso do precedente, ele deve ser solucionado por um procedimento contrário, isto é, os termos multiplicados por $\dot{x}$, sendo dispostos de acordo com as dimensões de $x$, devem ser divididos por $\frac{\dot{x}}{x}$, e então pelo número de suas dimensões, ou por alguma outra progressão geométrica. Assim, o mesmo trabalho deve ser repetido com os termos multiplicados por $\dot{v}, \dot{y}$ e $\dot{z}$. A soma resultante deve ser igualada a nada, rejeitando os termos que são resultantes (Newton, MW, v:1, p: 53).

Sendo o problema inverso, se no anterior a operação a ser utilizada era a multiplicação, agora os termos da equação devem ser divididos, já que multiplicação e divisão são operações inversas entre si. Assim como no primeiro problema, tomemos um dos exemplos de solução, a fim de expor o algoritmo apresentado por Newton. Não por 
acaso, ele começa mostrando o caminho inverso das equações tomadas no primeiro exemplo do Problema I.

Considerando a equação-solução encontrada na etapa anterior: 32 (2.2), deve-se remontar àquela que era a equação

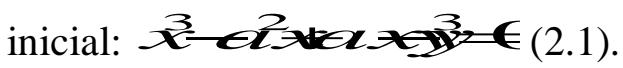

Newton apresenta o seguinte quadro, que condensa a solução proposta:

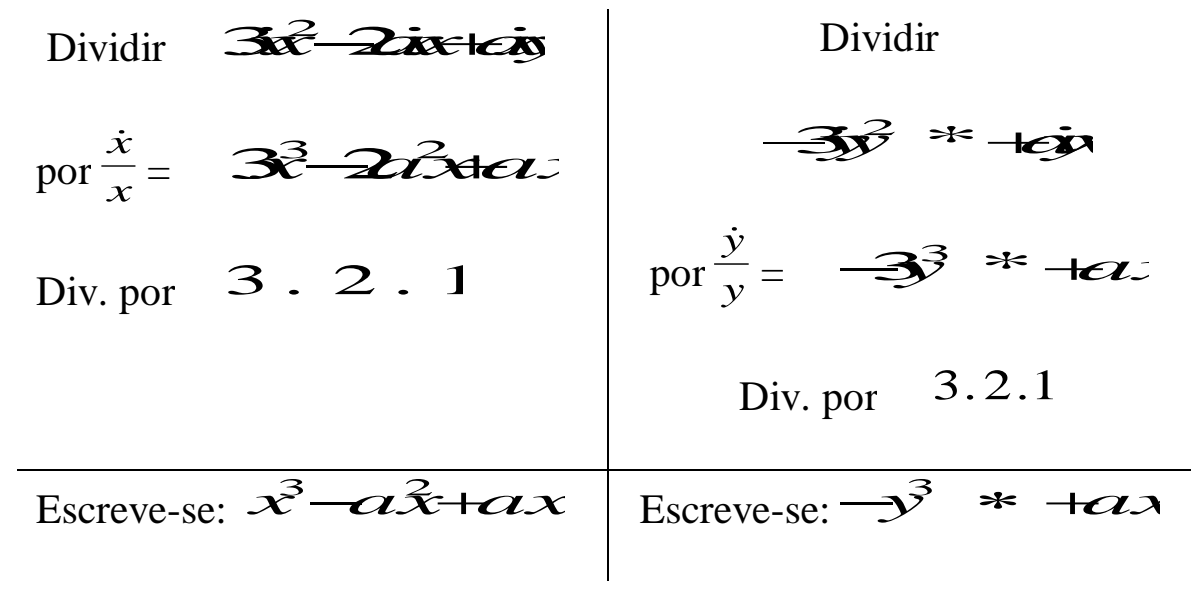

Vê-se, no entanto, que não se trata, estritamente, dos passos inversos da solução do primeiro problema. Pois, a partir da primeira linha, organizada de acordo com os índices de $x$ e $y$, realizam-se duas divisões: a primeira por $\frac{\dot{x}}{x}$ e $\frac{\dot{y}}{y}$; e a segunda pelos índices de $x$ e $y$ (presentes na terceira linha). Ao somar os resultados finais das duas colunas, expressos na última linha, deve-se ainda eliminar um dos termos repetidos. Assim, a equação final será 32

Embora Newton admita que a solução do segundo problema não tenha o mesmo grau de eficiência alcançado pela primeira solução (isso porque não alcança o mesmo grau de generalidade e precisa recorrer aos "casos particulares"), o que é preciso reter, para os nossos propósitos, é o caráter analítico de tais soluções. O recurso às equações e manipulações algébricas que elas possibilitam, parece fornecer ao método das fluxões 
newtoniano a generalidade que ele precisava. Ou seja, não sendo mais necessário considerar cada construção geométrica particular, o algoritmo apresentado no $D e$ Methodis pode ser aplicado, de maneira mais ampla, a qualquer curva da qual se conheça a equação. Porém, parece evidente que a diferença entre esse algoritmo e as soluções anteriores, ditas geométricas, não atinge os elementos mais fundamentais do método: tanto os problemas quanto os objetos matemáticos considerados são, qualquer que seja o procedimento para a solução, geométricos. Não é possível pretender, então, uma distinção que oponha a apresentação analítica do método das fluxões às soluções geométricas anteriores. Antes, as últimas se apresentam como soluções menos gerais que as primeiras, na medida em que dependem das construções geométricas que, inevitavelmente, exigem um tratamento particular. Nesse caso, cabe perguntar em que medida a articulação dessa chamada fase analítica da matemática newtoniana com o tal "retorno à geometria dos antigos" operado na maturidade se daria em um âmbito diferente do que vimos aqui. Em outras palavras, opera-se, nessa passagem, uma mudança mais radical que justificaria a delimitação de duas fases distintas? Já que, como foi visto, o recurso às construções geométricas não está restrito à etapa madura da matemática newtoniana, e, ao menos até este ponto, não pode ser compreendido em oposição ao método analítico, é preciso avançar em direção à apresentação geométrica do método das fluxões, contida nos Principia, a fim de fornecer novas bases à questão do realismo matemático.

\subsection{De volta à questão do realismo matemático}

Visto que a questão do realismo matemático de Newton se manifesta em um contexto em que o paralelo entre a análise e a síntese ocupa um estatuto central, é 
necessário delimitar o modo como esses dois âmbitos se desenvolvem no interior da obra newtoniana. A leitura mais corrente sustenta que houve uma "virada metodológica" constituída por uma mudança radical na orientação das concepções matemáticas de Newton. Ou seja, os resultados alcançados por Newton, utilizando-se da análise cartesiana, estavam consubstanciados no cálculo das fluxões, que Newton desenvolveu entre os anos 1664 e 1669, sob forte inspiração da Geometria de Descartes. Entretanto, no início da década de 1670, Newton teria regressado a uma concepção geométrica mais clássica na qual a linguagem analítica perde seu papel central num movimento de "retorno à geometria dos antigos". Em linhas gerais, essa leitura sustenta que houve uma ruptura do ponto de vista da orientação matemática na passagem para a etapa mais madura da obra de Newton. Essa tese representa a abordagem da maioria dos comentadores que se dedicaram a questões dessa natureza, tais como Arthur, De Gandt e Cajori. Os textos de Nicolò Guicciardini oferecem uma versão particularmente estruturada dos argumentos que constituem a abordagem da ruptura. Segundo ele, a prática matemática de Newton estaria, portanto, claramente dividida em dois períodos: o primeiro em que Newton desenvolve a nova análise cartesiana (e wallisiana) e que tem seu auge no De Methodis (escrito por volta de 1669 e publicado, postumamente, em 1736); e o segundo, um período sintético que culmina com os Principia em que o formalismo algébrico dá lugar à geometria, os infinitésimos são substituídos pelos limites e o método analítico dos modernos perde seu espaço para o método sintético dos antigos (Guicciardini, 2004, p. 467). Mesmo que haja um consenso em admitir alguma diferença na abordagem entre o Newton jovem e o maduro, ainda resta a questão de saber se essa divergência constitui propriamente uma ruptura. Se constituir, podem-se delimitar claramente dois períodos distintos e o problema a ser considerado será o de 
identificar a razão dessa ruptura. Nesse sentido, o comprometimento de Newton com o realismo matemático se oferece como um elemento essencial da resposta.

Entretanto, a tese de que houve uma ruptura radical entre a etapa analítica e a sintética não é uma unanimidade. Marco Panza (2001, p. 8) sustenta que essa tese da ruptura articula a relação entre a análise e a geometria de modo completamente equivocado. Segundo ele, essa relação não pode ser reduzida a uma oposição entre duas orientações distintas, dois modos de fazer matemática, dois modos de formular e resolver problemas, ou ainda, a um enfrentamento entre duas linguagens. A única distinção radical possível entre a análise e a geometria seria a caracterização de ambas como teorias matemáticas distintas e que, portanto, se referem a dois domínios distintos de objetos. Panza, no entanto, caracteriza a análise cartesiana como um novo modo de se fazer geometria, mas, ainda assim, trata-se de geometria já que contempla objetos geométricos como curvas, tangentes, centro de curvas etc.. Assim, não há sentido em se referir a um "retorno à geometria", pois as investigações de caráter analítico que levaram Newton à redação do De Methodis são investigações a respeito da geometria e seus resultados são geométricos. Desses mesmos resultados, podem-se extrair o núcleo argumentativo e os procedimentos matemáticos dos quais vai emergir a geometria diferencial dos Principia. Desse modo, pode-se dizer que Panza advoga a tese de que há uma continuidade na obra newtoniana garantida pelo caráter geométrico dos objetos, dos problemas e das resoluções em questão.

Esse novo cenário impõe a tarefa de pesquisar de que maneira a questão do realismo matemático pode ser posta diante da tese da continuidade, e, ainda, se ela pode ser posta diante dessa tese. Assumindo a preservação do caráter geométrico dos objetos da teoria das fluxões, como seria possível afirmar que a posterior opção pelo método sintético é devida a uma exigência, supostamente não cumprida pela análise, de um 
caráter geometricamente representativo dos símbolos das equações? Ou, reformulando o problema, como caracterizar o abandono por Newton desse algoritmo desenvolvido a partir dos métodos cartesianos? Panza sustenta que esses métodos cartesianos foram estendidos por Newton e combinados com os métodos de quadratura a ponto de sugerir a possibilidade de uma teoria autônoma complementar à geometria e não alternativa a ela, o que o permitiu chegar à teoria das fluxões. Os Principia seriam, então, não um abandono de todo o êxito alcançado pela etapa analítica, mas uma apresentação sintética cujo núcleo argumentativo preserva uma continuidade com relação à etapa inicial. No entanto, retorna aqui uma questão central: o que significa essa renúncia à apresentação analítica? Como compreender, a partir dessa perspectiva, a substituição da teoria das fluxões do De Methodis pela sua apresentação sintética nos Principia?

Diante dessas questões - embora sejam análogas àquelas postas frente à tese da ruptura - o problema do comprometimento de Newton com um realismo matemático ganha contornos mais complexos. Deixa de ser evidente que a razão para a passagem de uma etapa a outra sejam as exigências de ordem ontológica, já que os objetos dos primeiros resultados de Newton não deixam de ser geométricos. No entanto, cabe pesquisar que razões seriam estas e, consequentemente, se a exigência de um realismo matemático exerce ainda alguma função nessa passagem. 


\section{A CHAMADA "FASE SINTÉTICA" DA MATEMÁTICA NEWTONIANA}

Diante do alto índice de sucesso na resolução de problemas que o método cartesiano propiciou para a matemática da modernidade, Newton, ao menos no início do seu trabalho, é contado entre os seus seguidores. O método algébrico de Descartes, entre outros instrumentais matemáticos, possibilitou a Newton uma grande facilidade na solução de certos problemas; por exemplo, o problema de encontrar a tangente da curva, dada sua equação, o problema de encontrar a área delimitada por uma curva (conhecido como "quadrar a curva") e o problema de encontrar o comprimento do arco da curva. Entretanto, no início da década de 1670, Newton tece pesadas críticas aos modernos, mais especificamente a Descartes, no que diz respeito ao método de análise. Nessa mesma época, passa a dedicar-se ao estudo dos textos de geometria dos antigos (Pappus e Apollonius, por exemplo), o que culmina com o abandono progressivo da análise e, consequentemente, a reabilitação do método sintético dos antigos.

Na tentativa de compreender melhor esse retorno à geometria dos antigos, a seguinte passagem mostra-se particularmente esclarecedora:

Os geômetras antigos investigavam coisas buscando através da análise, demonstrandoas quando encontravam através da síntese, publicando-as quando demonstradas como elas poderiam ser recebidas na geometria. Eles não investiram imediatamente na geometria uma vez resolvida [resoluta] ${ }^{22}$ : existiu a necessidade de sua solução pela composição de suas demonstrações. Pois a força da geometria e seu grande mérito assentam-se na total certeza de seus assuntos, e certamente em suas demonstrações especificamente compostas. Nessa ciência considerou-se necessário ser compensado não somente pela concisão da escrita, mas também pela certeza das coisas (MP-8, p. 452-453).

Trata-se de um prefácio à segunda edição dos Principia que, porém, não chegou a ser publicado. Nela, Newton posiciona-se frente à afirmação de Descartes de que os antigos

\footnotetext{
${ }^{22}$ Segundo Whiteside, o termo "resoluta" se refere ao método de análise como método para solucionar problemas. Em outra versão, Newton teria utilizado o termo "problematum resolutiones", o que confirmaria essa interpretação (cf. MP-8, Nota 37. p. 453).
} 
omitiram a etapa analítica das demonstrações matemáticas, privando-nos do método pelo qual resolveram os problemas e deixando-nos apenas as provas das respectivas soluções. Newton, ao contrário, afirma que a certeza dos assuntos da geometria encontra-se na etapa sintética do método, ou seja, na demonstração.

Claramente, vemos que Newton está descrevendo o método de análise e síntese, assim como Descartes o faz. Também em conformidade com as afirmações de Descartes, ele atribui à etapa analítica a tarefa de solucionar os problemas e, à etapa sintética, o ônus de demonstrar a validade de tal solução. Em outra versão, também não publicada, do prefácio à segunda edição dos Principia, Newton afirma: "A análise dos antigos parece ter consistido na dedução de consequência de dados até que as coisas buscadas resultassem" (MP-8, p. 444-445). Entretanto, se, para Descartes, é a análise que deve ser considerada, visto que apenas ela representa um acréscimo na aplicação do método, Newton enfatiza o critério atribuído por ele aos antigos de que apenas a etapa sintética oferece o grau de certeza de que a geometria necessita. Portanto, Newton pode autorizar-se a seguir o exemplo dos geômetras antigos e omitir o processo pelo qual chegou à solução dos problemas, concentrando a exposição de seu método na demonstração dos mesmos.

Desse modo, a opção pela apresentação sintética de seu método aponta para o comprometimento de Newton com certos critérios e exigências que não se colocam diante da matemática cartesiana. Com o método das primeiras e últimas razões, exposto nos Principia, ele abre mão de uma álgebra das fluxões em proveito de uma geometria fluxional. A afirmação de que isso representa um retorno aos geômetras antigos é baseada em dois elementos característicos dessa mudança. Em primeiro lugar, como foi dito, a apresentação do método passa a ser sintética, a exemplo dos antigos. Além disso, o recurso à teoria das proporções aplicada às magnitudes geométricas substitui a ampla 
utilização de equações características da etapa analítica da matemática newtoniana, bem como da geometria de Descartes.

O propósito deste capítulo é inventariar os elementos centrais dessa mudança. O teor das críticas a Descartes, e, portanto, à primazia da apresentação analítica, aliado às opções matemáticas da apresentação sintética newtoniana, evidencia uma ontologia dos objetos matemáticos que não é explicitamente elaborada por Newton. Primeiramente, o estatuto das grandezas infinitamente pequenas, indivisíveis, que já se apresentava como um problema na época do De Methodis, segue como uma preocupação ainda mais relevante. O tratamento dado por Newton a essa questão sofreu transformações importantes no percurso da sua prática matemática. Tais transformações apontam para o comprometimento com critérios cada vez mais restritivos com relação à admissão de grandezas ficcionais na matemática. O método das primeiras e últimas razões dos Principia substitui essas grandezas infinitamente pequenas pela razão entre grandezas que surgem ou anulam-se através de um movimento. Do mesmo modo, a solução de Newton para o problema de Pappus denuncia o caráter não representativo dos termos empregados nas equações algébricas. O ponto central da crítica newtoniana a Descartes toca na falta de correspondência geométrica desses termos, ou seja, no fato de que alguns elementos das equações não nomeiam genuinamente nenhuma entidade matemática canônica (geométrica ou numérica). Novamente, o retorno à geometria dos antigos parece estar acompanhada de uma exigência ontológica mais rígida com relação aos objetos matemáticos. 


\subsection{O problema do estatuto do infinitamente pequeno}

Afirmar que Newton foi leitor de Descartes, aliás, um dos mais atentos de sua época, não é meramente um dado biográfico. As suas investigações matemáticas iniciais são marcadas por uma opção metodológica fortemente cartesiana: a análise, como um procedimento investigativo para o desenvolvimento de soluções matemáticas. Embora Newton faça também referência à análise dos matemáticos gregos, é inegável a influência de Descartes no que diz respeito ao tratamento de determinados problemas, particularmente aqueles que permitem expressar curvas por meio de equações e estudar as propriedades das curvas manipulando essas equações. Descartes seria, então, não o único, mas o principal representante daquilo que Newton chamou de nova análise, para distingui-la da análise dos antigos.

A fim de caracterizar melhor o que Newton estaria tomando por nova análise, considero a seguinte afirmação: “A análise dos mais recentes tem sua origem na aritmética, e é nada além do que uma aritmética universal aplicada a uma quantidade, seja ela geométrica ou alguma outra qualquer" (Newton. MP. 1967-1981. V.8, p. 444). Fica evidente a possibilidade de uma referência à geometria cartesiana. A universalidade da aritmética em questão remete à transposição dos limites entre a aritmética e a geometria que Descartes preconizou. Aquelas regras, antes restritas às operações da aritmética, passam a ser aplicadas às quantidades geométricas, como foi exposto anteriormente. Tanto as quantidades geométricas quanto as numéricas passam a ser representadas por símbolos que extrapolam o âmbito das quantidades particulares, fornecendo um caráter universal às regras que os manipulam. Assim, as equações compostas por esses símbolos e obedientes a tais regras podem representar, por exemplo, as curvas geométricas. 
Porém, é preciso destacar que, embora o método analítico cartesiano seja uma fonte importantíssima para a nova análise, existem outras fontes que possibilitaram o progresso que Newton alcançou nesta fase inicial dos seus trabalhos. Segundo N. Guicciardini (2004, p.455-70), a nova análise, pode ser caracterizada por três elementos principais, a saber, a representação simbólica cartesiana das curvas por equações, o uso do infinitamente pequeno e o uso das técnicas de indução wallisianas ${ }^{23}$, que, no entanto, não serão contempladas aqui. Um dos resultados mais significativos propiciados pela nova análise newtoniana diz respeito à utilização das infinitas séries na quadratura das curvas. O trabalho de Wallis propõe uma solução para a quadratura de curvas que, porém, restringe-se apenas a equações que comportam um número finito de termos; ou seja, equações do tipo $y=x^{3}$. Os resultados que Newton obtém permitem fornecer a área de curvas geradas por equações de "termos compostos", isto é, equações que podem conter séries infinitas de termos. Por exemplo,

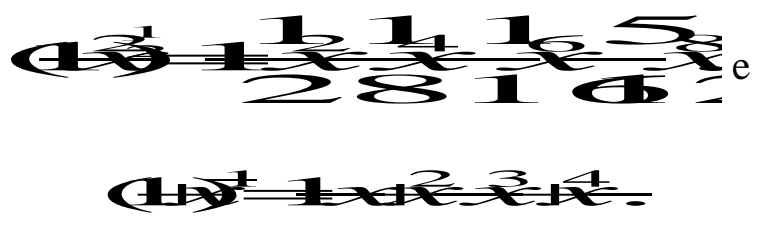

Entretanto, para chegar à solução de problemas dessa ordem, ele acaba recorrendo ao uso de uma espécie de magnitude no mínimo peculiar: o infinitamente pequeno. A utilização do infinitamente pequeno por Newton, e os obstáculos conceituais que ela implicará, é um dos fatores que contribuirão, posteriormente, para o rompimento com a análise em favor da síntese.

Não se pode negar que os métodos algébricos de Descartes possibilitaram a Newton uma grande facilidade e eficiência na solução de problemas. Entretanto, o problema do estatuto do infinitamente pequeno começa a ganhar proporções difíceis de

\footnotetext{
${ }^{23}$ A principal contribuição de Wallis para o trabalho de Newton diz respeito às regras para quadrar as curvas.
} 
serem ignoradas. Referindo-se à sua tentativa de converter o método cartesiano para encontrar a subnormal em um método geral para encontrar tangentes e curvaturas, utilizando um incremento infinitesimal, Newton manifesta dúvidas quanto ao status desse incremento: "não podemos considerar boa ideia a menos que o infinitamente pequeno possa ser considerado geometricamente" (Newton. MP. 1967-1981. V.1, p. 282). ${ }^{24}$ Com base nesta passagem, pode-se dizer que o estatuto controverso do infinitamente pequeno reside, principalmente, na falta de uma correspondência geométrica. Isso porque, ele reúne duas características aparentemente inconciliáveis. Prima facie, o infinitamente pequeno é uma quantidade, na medida em que pode ser somado a outras quantidades finitas. Porém, embora lhes possa ser somado, ele não pode alterá-las, pois não é mensurável por outras grandezas também de ordem finita. Sendo assim, embora seja uma quantidade, o infinitamente pequeno não encontra um correspondente na geometria.

Como foi dito no capítulo anterior, a teoria das proporções de Eudoxo, apresentada no Livro V dos Elementos de Euclides, trata das grandezas contínuas, incluindo as geométricas. Esta era, na época de Newton, a única teoria a oferecer as bases para o tratamento desse tipo de quantidade. Euclides toma como um dos fundamentos da teoria das proporções a exigência da homogeneidade. No caso das quantidades contínuas, para que se possa estabelecer qualquer tipo de relação de proporção entre, por exemplo, dois pares de grandezas, é preciso que as duas grandezas que constituem cada par sejam, necessariamente, do mesmo gênero; isso porque elas não possuem uma medida comum a exemplo das grandezas numéricas, que são evidentemente grandezas discretas.

\footnotetext{
${ }^{24} \mathrm{O}$ texto Normals, Curvature and the Resolution of the General Problem of Tangents foi escrito em 1664 e publicado no ano seguinte. Nele, Newton trata do (incremento) infinitamente pequeno na construção da subtangente e na determinação da quadratura da curva: dois dos problemas mais significativos do início dos trabalhos matemáticos de Newton.
} 
Os compromissos de Newton com os fundamentos matemáticos euclidianos se deixam transparecer justamente na sua preocupação com o problema da homogeneidade. A equação, considerada essencialmente como uma proporção generalizada, a exemplo de Euclides, exige que se cumpra o requisito da homogeneidade mencionado acima. Desse modo, ela deve comportar apenas quantidades da mesma espécie e, a fortiori, do mesmo grau. Se alguns dos seus termos representam quantidades geométricas, assim deve ser para todos os demais termos da equação. Ao questionar a correspondência geométrica de alguns elementos utilizados na análise dos modernos, Newton tem em mente uma violação generalizada da exigência da homogeneidade.

\subsection{O estilo sintético de Newton: o método das primeiras e últimas razões}

O tratamento dado por Newton ao infinitamente pequeno transforma-se, como visto acima, ao longo de sua trajetória matemática. A partir dos anos de 1670, os momentos e fluxões serão colocados de lado em proveito de uma nova abordagem: o método das primeiras e últimas razões, cujo desenvolvimento encontra-se nos Principia. Nesse método, o elemento infinitamente pequeno, imprescindível para o sucesso alcançado pelos matemáticos da época, é completamente desassociado das quantidades, o que elimina o tão problemático apelo às "quantidades infinitamente pequenas". No lugar delas, são introduzidas razões de quantidades que permitirão a Newton usufruir da mesma eficiência matemática contornando, no entanto, certos problemas que o próprio Newton detectou em seus antigos métodos algébricos expostos, em sua versão mais madura, no De Methodis. 
No início do Livro I, Seção I, dos Princípios matemáticos da filosofia natural (1687) [Principia], Newton apresenta, em 11 Lemas, o conceito de primeiras e últimas razões. Trata-se de uma apresentação geométrica que não apenas introduz o conceito, mas estrutura o próprio método das primeiras e últimas razões. É esse método que será utilizado na obra e que caracterizará a maturidade da matemática newtoniana. No Escólio final a esses lemas, Newton afirma:

Portanto, se, de agora em diante, eu vier a considerar as quantidades como formadas por partículas, ou vier a tomar pequenas linhas curvas como retas, isso não significará quantidades indivisíveis, mas quantidades divisíveis evanescentes; nem as somas e razões de partes determinadas, mas sempre o limites das somas e das razões, a força de tais provas [das demonstrações que se seguem] depende sempre do método exposto nos lemas precedentes (Newton, 1999, p. 441).

Não restam dúvidas, portanto, de que Newton não está considerando as quantidades como infinitamente pequenas e, portanto, indivisíveis. Ao contrário, trata-se de quantidades divisíveis que estão nascendo ou evanescendo. Do mesmo modo, serão considerados os limites das somas e razões e não as próprias somas e razões. Esses fundamentos anunciados aqui merecerão, em seguida, uma explicação mais detalhada.

Primeiramente, considero as quantidades nascentes e evanescentes. Antes de tudo, elas são quantidades geométricas garantidas por dois elementos que já estavam presentes no De Methodis: o caráter cinemático da geometria e o estatuto privilegiado do tempo. Porém, embora tal privilégio não seja inaugurado pelos Principia, nessa obra o tempo ganha contornos ainda mais significativos, o que Newton expõe claramente no Escólio às Definições:

Tempo absoluto, verdadeiro e matemático (...) sem referência a nada externo e que flui uniformemente, é também chamado de duração. Tempo relativo, aparente e comum é qualquer medida externa e sensível da duração. (Newton, 1999, p. 408) 
Desde o primeiro lema, o tempo é condição constituinte de toda entidade geométrica, exercendo um papel fundamental tanto neste lema quanto naqueles que se seguem. Desse modo, o tempo matemático é, para Newton, o tempo absoluto, a duração. O mesmo tempo absoluto sem o qual a existência das coisas não estaria garantida, pois as coisas existem obrigatoriamente em uma relação espaço-temporal. E, por ser absoluto, esse tempo não é resultado do movimento que ocorre no espaço. Ele não é perceptível. De outro lado, o tempo que é percebido através do movimento é o tempo aparente que é impreciso e cuja medição deve ser regularmente submetida a correções. O tempo verdadeiro, mencionado já no De Methodis, é esse tempo absoluto e preciso, independente do movimento e de qualquer tempo aparente. Assim, o tempo absoluto é também o tempo matemático, pois, se fosse de outra forma, toda a imprecisão do tempo aparente seria transportada para o método. Ao contrário, o tempo matemático, fluente, é exato. E, se por um lado, é evidente que a geometria não pode prescindir do espaço, a concepção cinemática da matemática newtoniana estabelece, igualmente, uma dependência da geometria com relação ao tempo, considerado no sentido absoluto.

Essa concepção do tempo, que perpassa os Principia como elemento fundamental do método das primeiras e últimas razões, já estava enunciada na noção de tempo verdadeiro no método das fluxões do De Methodis. As magnitudes geométricas são, nesse contexto, entidades submetidas a processos contínuos de "geração". Tais processos se dão pelo movimento que ocorre no tempo fluente, ou seja, o movimento tem um caráter gerador na construção das figuras geométricas. Linhas são geradas pelo movimento de planos, planos pelo movimento de linhas e sólidos pelo movimento de planos. Porém, ao especificar que o espaço e o tempo geométricos são os mesmos espaço e tempo absolutos, os Principia conferem ao processo de geração um 
comprometimento ontológico ainda mais radical, visto que trata-se dos mesmos espaço e tempo absolutos que são condição de tudo aquilo que existe. Lê-se no manuscrito $D e$ Gravitatione: "Tempo e Lugar em si mesmos são afecções de todas as coisas, sem o que nada [...] pode existir. Todas as coisas estão no tempo com respeito à duração de existência e no espaço com respeito à amplitude de presença". Esse movimento gerador ou aniquilador não deve ser tomado, portanto, de maneira ficcional ou mesmo instrumental. Embora Newton não desenvolva propriamente uma ontologia dos objetos matemáticos ou dos objetos da natureza e ainda que nem todos os critérios estejam explícitos, pode-se afirmar que as quantidades nascentes ou evanescentes da geometria não são menos reais que qualquer outra magnitude cuja existência dependa da relação que ela mantém com o espaço e o tempo.

Além das noções de quantidades nascentes e evanescentes, os Principia apresentam outro conceito fundamental para o método das primeiras e últimas razões: o conceito de limite ${ }^{25}$. O Lema I introduz esse conceito:

Lema I: Quantidades, e também razões de quantidades, que em qualquer tempo finito tendem constantemente para igualdade, e que antes do fim desse tempo aproximam-se tanto uma da outra que sua diferença é menor do que qualquer quantidade dada, tornam-se ultimamente iguais.

A demonstração se desenvolve por meio de uma redução ao absurdo:

Se você nega isso, suponha como finalmente desiguais, e deixe sua última diferença ser $D$. Então, elas não podem se aproximar mais para a igualdade do que por sua diferença dada $D$, contrariando a hipótese (Newton, 1999, p. 433).

Nota-se a delimitação de um intervalo de tempo no qual ocorre o movimento em questão. O limite é, então, o ponto de chegada do movimento. Esse movimento é garantido pelo tempo matemático, que flui de modo constante; mas, também, pode ser delimitado ao se considerar finito o intervalo no qual se dá o movimento. Com o

\footnotetext{
${ }^{25} \mathrm{O}$ conceito de limite não aparece nos manuscritos anteriores aos Principia, com exceção do manuscrito Geometria Curvilinea (1680) que apresenta tal conceito, embora de maneira menos desenvolvida.
} 
propósito de assegurar a relação de igualdade entre as quantidades, ou razões de quantidades, Newton estabelece que a tendência daquele movimento é o de torná-las iguais, o que ocorrerá, naturalmente, no fim do movimento. Porém, imediatamente antes de finalizar o intervalo de tempo considerado, ou seja, quando a diferença entre elas é menor do que qualquer diferença dada, elas são tomadas como iguais.

Desse modo, grandezas que eram inicialmente desiguais podem estabelecer uma relação de igualdade que não é possível no âmbito das grandezas finitas mas que, com a introdução da noção de limite, podem ser consideradas iguais. Esse recurso, garantido pela noção de limite, possibilitará, nos lemas posteriores, que quantidades sejam substituídas por outras quando ambas estiverem em estado nascente ou evanescente. Por exemplo, uma curva poderá ser substituída por sua tangente, e vice-versa, contanto que isso ocorra no limite inicial ou final do movimento, pois seus movimentos nascentes ou evanescentes no limite estarão em razão de igualdade.

Como exemplo da utilização do conceito de limite para determinar as razões de igualdade, nos Principia, é interessante considerar o Lema 7. O que Newton pretende determinar nesse lema é a razão de igualdade entre arco, corda e tangente de uma curva:

Lema 7: supondo-se as mesmas coisas [as do Lema 6], afirmo que a razão última entre arco, a corda e a tangente, entre qualquer um e qualquer outro, será a razão de igualdade.

Newton prossegue com a seguinte demonstração:

Pois, enquanto o ponto $B$ aproxima-se do ponto $A$, consideremos sempre que $A B$ e $A D$ são produzidos para os pontos afastados $b$ e $d$; e, em paralelo à secante $B D$, tracemos $b d$; e que o arco $A c b$ seja sempre semelhante ao arco $A C B$. Então, supondo que os pontos $A$ e $B$ coincidam, o ângulo $d A b$ desaparecerá, conforme o Lema 6; e portanto, as retas $A b$ e $A d$ (que são sempre finitas) e o arco intermediário $A c b$ coincidirão e se tornarão iguais entre si. Donde as retas $A B$ e $A D$ e o arco intermediário $A C B$ (que são proporcionais aos primeiros) desaparecerão, e acabarão adquirindo a razão de igualdade. Q.E.D (Newton, 1999, p. 436). 
Newton escolhe um movimento como referência que, no caso, é o movimento evanescente do ponto $B$ em direção ao ponto $A$, anulando, assim, o arco $A B$. O que está em questão no Lema 7 é definir o que acontece com as demais quantidades quando o $\operatorname{arco} A B$ se anula. Ou seja, é claro que, ao final, arco, corda e tangente se anulam simultaneamente. Porém, o que interessa a Newton é estabelecer o que acontece no limite, antes do fim.

Considerando que $\mathrm{AD}$ seja a tangente do arco $\mathrm{AB}$, ao fazer com que o ponto $\mathrm{B}$ se aproxime de A, a secante BD deve, igualmente, anular-se. Isso porque, sendo o arco uma curva contínua, exatamente no ponto que a tangente toca a curva, o ponto $\mathrm{D}$ coincidirá com o ponto A. E isso, segundo Newton, é garantido pelo Lema 6:

Se um arco ACB [ver Figura 5], dado numa posição, for subtendido por sua corda $\mathrm{AB}$, e num ponto $\mathrm{A}$ qualquer, no meio da curvatura contínua, for tocado por uma reta $\mathrm{AD}$, produzida em ambos os sentidos, então, se os pontos $\mathrm{A}$ e $\mathrm{B}$ se aproximarem e se encontrarem, afirmo que o ângulo $\mathrm{BAD}$, contido entre a corda e a tangente, diminuirá in infinitum e acabará desaparecendo (Newton, 1999, 435).

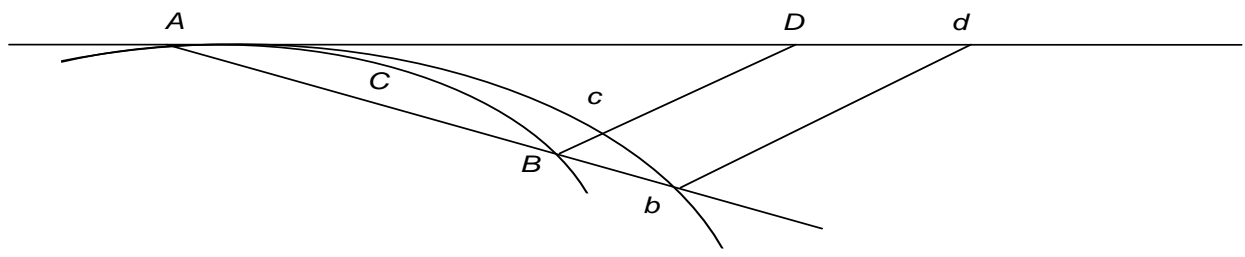

Figura 5 
Para determinar as razões de igualdade, Newton introduz um segundo arco $A b, \mathrm{e}$, consequentemente, as outras quantidades: a corda $A b$, a tangente $A d$ e a secante $b d$. Ou seja, Newton constrói a figura de modo que diversas quantidades finitas possam ser colocadas em proporção. A seguir, conduz ao limite um dos lados da proporção, enquanto que o outro permanece finito: antes do ponto $A$ coincidir com o ponto $B$, todas as quantidades relacionadas ao $\operatorname{arco} A B$ (a corda $A B$, a tangente $A D$ e a secante $B D$ ) podem ser colocados em relação de proporcionalidade como as quantidades do arco $A b$ (a corda $A b$, a tangente $A d$ e a secante $B d$ ). Segundo Newton, se as quantidades relacionadas ao arco $A b$ permanecerem finitas, não se anulando como as quantidades relacionadas ao arco $A B$, elas deverão assumir razões de igualdade. Assumindo que é assim, pode-se dizer de maneira mais geral, que se duas quantidades geométricas finitas $X$ e $Y$ estão em proporção como outras duas quantidades geométricas finitas $x$ e $y$, então, para Newton, o cancelamento de $X$ e $Y$ não impede que ainda exista uma relação de proporcionalidade, caso $x$ e $y$ permaneçam finitos. O que Newton assegura é que no estado final, do movimento do ponto $B$ em direção ao ponto $A$, ainda existirá uma proporção similar a:

$$
0: 0:: y: x
$$

Portanto, os limites para as quantidades finitas são as quantidades que se esvanescem. E, de acordo com o Lema 1, quando essas se esvanescem, no estado limite, não existirá diferença entre elas. Entretanto, quando consideradas na relação de proporcionalidade com as quantidades finitas, para Newton, o fato de não haver diferença fará com que, na proporção, existam somente razões de igualdade. Newton acredita que com isso uma das características principais da geometria clássica está preservada: a possibilidade de colocar quantidades em relação de proporção sem afetar a homogeneidade, isto é, que somente quantidades da mesma natureza fossem 
comparadas. Nesse sentido, trata-se de uma propriedade finita, determinada ainda quando as quantidades são finitas, e que se preserva quando uma das razões da proporção chega ao seu limite.

Assim, o estado limite permite que as quantidades assumam uma relação de igualdade. Ou seja, Newton não precisa mais se comprometer com quantidades infinitamente pequenas, pois, a relação de igualdade não determina a magnitude das quantidades nascentes ou evanescentes. O que ela determina são as razões de quantidades primeiras e últimas. Isso significa que, para Newton, uma relação geométrica pode se manter mesmo quando as quantidades diminuem indefinidamente até o limite. Do mesmo modo, Newton pode abrir mão de recursos algébrico-analíticos. Este é um exemplo do famoso retorno aos geômetras antigos, na medida em que se estabelecem as condições pelas quais as relações geométricas se preservam. O que extrapola o âmbito da geometria clássica é que tais condições são estabelecidas na passagem ao limite.

\subsection{O retorno ao método sintético dos antigos e a solução de Newton para o problema de Pappus}

Entre 1670 e 1671, após completar o De Methodis (1670-71), Newton escreveu um adendo apresentando uma "abordagem mais natural" aos mesmos problemas desenvolvidos no corpo do texto. Tal abordagem era baseada em demonstrações a partir de axiomas, um procedimento característico do método sintético. Embora as críticas ao uso do infinitamente pequeno e a outros elementos da análise sejam encontradas em textos anteriores a este, o apêndice que será reformulado em 1680, dando origem à Geometria Curvilinea, é aceito pela maior parte dos comentadores como um marco na 
transição do método analítico para o sintético. Pode-se dizer que esse apêndice é resultado do crescente interesse de Newton pelos escritos geométricos dos geômetras antigos, que acompanhou as - também crescentes - críticas ao simbolismo abstrato dos modernos. Nos anos 70, Newton dedicou-se ao estudo das Coleções de Pappus e à reconstituição feita por Fermat do Plane Loci de Apollonius. Desses estudos, resultaram dois manuscritos dedicados à "restauração do locus solido dos antigos" (Veterum Loca Solida Restituta), que são precedidos das seguintes palavras a título de um discurso preliminar:

Com relação ao seu tratamento desse problema [de Pappus], Descartes promoveu um grande espetáculo como se ele tivesse alcançado algo que no passado fora tenazmente buscado pelos antigos e em cujo beneficio Apollonius escrevera seus livros sobre as cônicas. Com todo respeito a um tão grande homem, não acredito que este tópico tenha restado como um mistério para os antigos. Pois Pappus nos fala de um método para traçar uma elipse através de cinco pontos dados e o raciocínio seria idêntico no caso das outras cônicas. E se os antigos sabiam como traçar uma cônica através de cinco pontos dados, como é que alguém pode não enxergar que eles descobriram a composição do locus sólido? (Newton. MP. 1967-1981. V.4, p. 275)

A escolha do problema de Pappus para pôr em evidência o conteúdo da crítica a Descartes deve-se ao fato de que, como está exposto no capítulo anterior, o próprio Descartes elegeu esse problema para mostrar a superioridade do seu método com relação ao método dos antigos. A retomada dos antigos proposta por Newton, tem, justamente por isso, o problema de Pappus como um dos pontos de partida. A passagem acima deixa clara a defesa do método dos antigos no sentido de que não lhes teria faltado aparato matemático para resolver o problema. Ou seja, pode-se, perfeitamente, encontrar a solução para os demais números de linhas e para as demais cônicas, sem precisar abrir mão, no entanto, do método que eles utilizavam. É exatamente isso que Newton se propõe a fazer nos manuscritos supracitados e, posteriormente, nos

\section{Principia.}


O propósito fundamental do Veterum Loca Solida Restituta é contestar a tese cartesiana de que o método dos antigos não foi capaz de fornecer uma solução satisfatória para o problema do locus sólido para três e quatro linhas. Para tanto, Newton se propõe a reconstruir a solução dos antigos para a construção da cônica através de três e cinco pontos dados, argumentando que, se os antigos obtiveram tal êxito, não há porque duvidar de que seu método fosse capaz de resolver com o mesmo sucesso o problema de Pappus em sua formulação mais completa. Tratarei aqui da construção da cônica a partir de três pontos dados, supondo que seja suficiente para ilustrar o alcance da mudança metodológica considerada.

A passagem a seguir deixa evidente o componente anti-cartesiano da virada metodológica de Newton para a síntese:

Para ser exato, o método deles [dos antigos] é consideravelmente mais elegante que o método cartesiano. Pois, por esse último, obtém-se o resultado por um cálculo algébrico que, quando transposto em palavras (seguindo a prática dos antigos em seus escritos) é tão tedioso e complicado a ponto de provocar náusea, além de não ser inteligível. Os antigos, ao contrário, realizaram o mesmo por meio de algumas proposições simples, julgando que qualquer coisa escrita num estilo diferente não mereceria ser lida e, por conseguinte, ocultando a análise pela qual obtiveram suas construções. Para mostrar que esse tópico não representava nenhum mistério para eles, tentarei restaurar suas descobertas seguindo os passos do problema de Pappus. (Newton. MP. 1967-1981. V.4, p. 277)

Afirmar que o método cartesiano peca por falta de elegância pode não parecer, ainda, uma crítica forte o suficiente para descartá-lo - até porque essa crítica é feita do ponto de vista do próprio método dos antigos, dependendo de que o método de Descartes seja "transposto em palavras (seguindo a prática dos antigos em seus escritos)". O ponto mais grave da crítica é, no entanto, a acusação de ininteligibilidade.

\footnotetext{
${ }^{26}$ Researches into the 'solid locus' reúne um conjunto de textos, escritos no final da década de 1670. São pesquisas acerca do tratamento dos antigos para problemas referentes às cônicas. Os dois manuscritos considerados aqui fazem parte desse conjunto.
} 
Não há como afirmar, de forma precisa, o que Newton quer dizer exatamente com o termo 'inteligível'. Minha leitura é a de que ele aponta para a falta de correspondente geométrico de alguns dos elementos mais importantes desse método, que, como já foi dito, é a ausência de um correlato ontológico para os termos das equações e sua potencial extensão às grandezas de ordem infinitesimais. Entretanto, as razões que Newton aponta para preferir o método dos antigos são outras. Em primeiro lugar, ele é mais simples. Em segundo lugar, ele dá conta dos mesmos problemas que Descartes pretende ter resolvido; porém, sendo mais simples, o faz de modo mais elegante.

Em resposta à acusação de Descartes de que os antigos teriam privado a posteridade de sua análise, ou seja, do processo pelo qual obtiveram seus resultados, Newton sustenta que os antigos julgaram que nada que estivesse escrito num estilo diferente da síntese mereceria ser lido e, por isso, ocultaram a análise. Essa tese não é uma novidade newtoniana. Ao contrário; segundo Whiteside, era uma tese amplamente popular nesse período que os antigos teriam vestido suas deduções matemáticas no traje sintético das proporções, seguindo um ideal lógico que ditava que a primeira análise pela qual elas foram originalmente derivadas deveria ser ocultada. (Whiteside, 1981, in Newton. MP. 1967-1981. V.4, p. 223). Vê-se, neste ponto, um apelo à autoridade dos antigos. Sustentada por essa autoridade, está consolidada, então, a opção pela síntese, pelo método dos antigos, em substituição à análise dos modernos e seus "cálculos algébricos".

Finalmente, após reconhecer que os antigos ocultaram o processo de descoberta que envolveu a solução dos problemas, Newton se propõe a reconstruir seus passos sem, no entanto, recorrer a qualquer procedimento analítico. O que ele faz, ao invés disso, é uma reconstrução do modo como os antigos teriam resolvido o problema do locus 
sólido para três e cinco pontos dados. Tal reconstrução é, obviamente, geométrica e inteiramente pautada por um procedimento sintético.

Para cumprir essa tarefa de "seguir os passos do problema de Pappus", Newton propõe dois problemas: (i) descrever uma cônica através de três pontos dados $A, B$ e $C$ e um centro dado $O$; (ii) descrever uma cônica através de cinco pontos dados $A, B, C, D$ e $E$. Basta apresentar o desenvolvimento do primeiro deles para pôr em evidência que a tentativa de reconstruir a solução dos antigos para o problema de Pappus está inteiramente baseada nas seções cônicas.

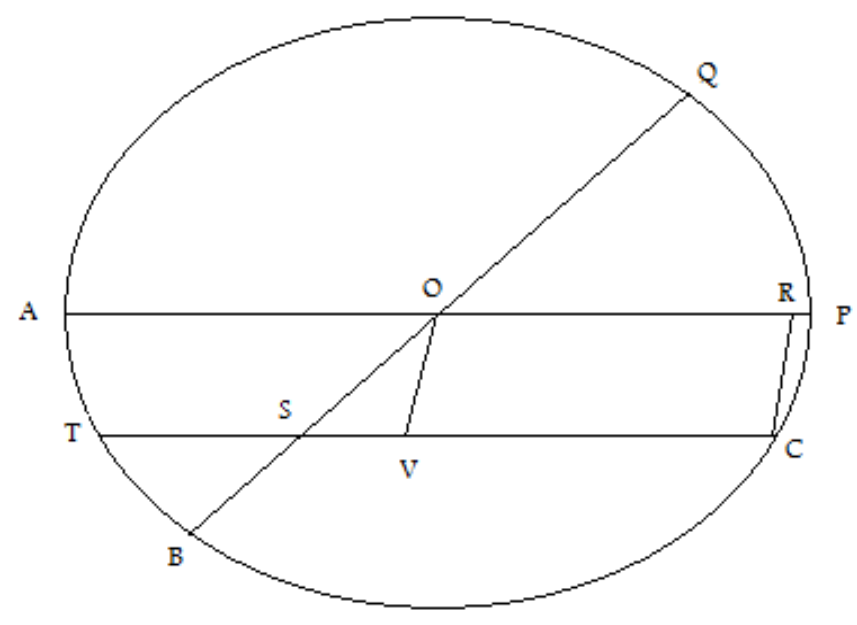

Fiaura 6

O enunciado do problema é exatamente o que está apresentado acima: “descrever uma cônica através de três pontos dados $A, B$ e $C$ e um centro dado $O$ ”. O primeiro passo é traçar linhas retas partindo de $A$ e $B$ em direção ao centro; essas linhas são chamadas $A O$ e $B O$, respectivamente. Em seguida, deve-se estender $A O$ até $P$ tal que $O P=A O$. Desse modo, $A$ e $P$ pertencem à curva e estão alinhados, são as extremidades de uma mesma linha. A partir de $C$, traça-se $C S$ paralela a $A O$ e cortando $O B$ em $S$. Considerando-se um ponto T na curva e pertencendo ao prolongamento da linha SC, tem-se a seguinte relação: 


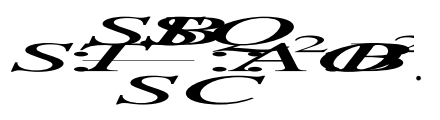

Sabe-se que $\boldsymbol{A} \boldsymbol{\mathcal { O }}=\boldsymbol{B \mathcal { O }}$, portanto, pode-se dizer que $S \boldsymbol{S E} \frac{S \boldsymbol{B S C}}{S C}$. O ponto Q é um ponto que está situado na curva, onde ela é tocada pela reta $B O$; ou seja, é o ponto oposto a $R$, na reta, com relação a $O$. Por uma simples manipulação algébrica: SWESA'! que é um teorema da definição geral de cônicas, assumido por Apolônio. Em linhas gerais, $S$ é o ponto de intersecção das retas $T C$ e $B Q$, sendo que $T$, $C, B$ e $Q$ pertencem à curva. A multiplicação dos dois segmentos ( $S T$ e $S C$ ) da reta $T C$ cortada por $S$ é igual à multiplicação dos dois segmentos $(S B$ e $S Q)$ da reta $S Q$ que intercepta $T C$ em $S$.

Biseccionando-se $T C$ em $V$, encontra-se a reta $V O$. Paralela a esta reta, traça-se $C R$ cortando $A O$ em $R$. Tem-se que $A P$ é o diâmetro e $C R$ será, então, sua ordenada. $\mathrm{O}$ lactus rectum estará para o diâmetro $A P$ como $C R^{2}$ está para $A R . P R$, por definição. Chega-se, então, a um critério para classificar a curva considerada no problema: se $\mathrm{R}$ estiver entre A e $\mathrm{P}$, a curva será uma elipse. Caso contrário, será uma hipérbole. A parábola não tem um centro cuja posição possa ser determinada por um segmento finito. Ela será construída no problema seguinte, por meio de quatro pontos dados. O locus, então, é determinado através das relações que se estabelecem entre os elementos considerados, ou seja, através das propriedades geométricas das cônicas.

O segundo problema proposto, a saber, o de descrever uma cônica através de cinco pontos dados, é resolvido de maneira bastante semelhante. O problema anterior fornecia três pontos e o centro da cônica. Esse, já que fornece apenas os pontos (que agora são cinco), tem com primeiro passo de sua solução encontrar o centro. A partir daí, a solução prossegue tratando de estabelecer as relações entre os elementos da curva, 
obedecendo às propriedades fundamentais das cônicas para determinar o locus a que pertencem os pontos dados.

No parágrafo que encerra essa seção, Newton afirma que esse parece ser o método mais natural para resolver o problema. Isso, não apenas por que é mais simples, mas, ele prossegue:

(...) já que a primeira parte do problema [de Pappus] (na forma proposta pelo próprio Descartes) é encontrar algum ponto, tendo uma dada condição, e em seguida, já que existe uma infinidade de pontos nesta classe, determinar o locus onde eles se encontram. O que pode ser mais natural do que reduzir as dificuldades dessa última parte àquela, de forma a determinar o locus de vários pontos após tê-los encontrado? Consequentemente, já que os antigos desenvolveram um procedimento para construir uma cônica através de cinco pontos dados, ninguém deveria duvidar de que eles construíram o locus sólido por esse meio. (Newton. MP. 1967-1981. V. 4, p. 283)

Essa passagem expõe de modo conciso a diferença entre o método que Descartes utiliza para resolver o problema e o método que Newton pretende ter reconstruído a partir dos antigos. Esse último consiste em reduzir as dificuldades da segunda parte do problema (determinar o locus onde se encontra a infinidade de pontos que cumpre as condições iniciais) à primeira parte (encontrar um dos pontos). Isso significa que o método consiste em encontrar vários pontos que cumprem as condições do enunciado e, em seguida, estabelecer a que curva eles pertencem. Por esse método, os antigos teriam chegado a um procedimento para construir uma cônica, dados cinco pontos e, justamente por isso, não haveria motivos para duvidar de que seu método fosse suficiente para resolver o problema em sua totalidade.

Tendo apresentado o que considera uma reconstrução do modo como os antigos chegaram à composição do locus sólido, Newton passa a desenvolver, no texto seguinte, sua própria solução para o problema de Pappus, pautando-se pelo método dos antigos. ${ }^{27}$

\footnotetext{
${ }^{27}$ Solutio Problematis Veterum Loco Solido trata, mais especificamente, da solução de Newton para o problema de Pappus. Pode-se dizer que essa é uma primeira formulação do que constituiria mais tarde as seções IV e V do Livro I dos Principia.
} 
Do ponto de vista dos avanços matemáticos que a análise dos modernos significou para os trabalhos iniciais de Newton, esse retorno ao método dos antigos representa uma renúncia a um dos expedientes mais significativos de tais avanços: a possibilidade das curvas serem expressas por equações, nas quais estão implícitas as razões entre as quantidades associadas à curva. Ao abrir mão desse expediente matemático capaz de contemplar toda a infinidade de pontos da curva através da mesma equação em benefício de um procedimento que necessita considerar individualmente alguns dos pontos da curva e, por composição, determinar seu locus, Newton está abrindo mão de algo que ele próprio considerou um grande avanço em seus primeiros escritos matemáticos. Essa prática, portanto, reafirma a gravidade da crítica dirigida ao método analítico, na medida em que a falta de correspondência geométrica de certos elementos utilizados na equação é, para Newton, razão suficiente para renunciar ao que antes era contado como um grande avanço matemático.

As seções IV e V do Livro I dos Principia são inteiramente dedicadas à geometria das cônicas. Cohen, em um capítulo introdutório ao texto ${ }^{28}$, afirma que essas duas seções constituíam um tratado à parte bem anterior aos Principia, e que foram incorporados ao texto por servirem de fundamento para questões relativas à órbita dos corpos celestes. Os manuscritos que formam o conjunto intitulado Researches into the 'solid locus', citados acima, são uma primeira formulação, mas não a única, da apresentação newtoniana do problema de Pappus que acabou por constituir as seções IV e V do Livro I dos Principia.

Por ser uma obra da maturidade de Newton, vemos nesse texto já consolidada a opção pelo método dos geômetras antigos em oposição ao método dos modernos. Pode-

\footnotetext{
${ }^{28}$ Comentário introdutório ao texto dos Principia, na edição de 1999, p.136-137.
} 
se dizer que o Lema XIX concentra propriamente os passos da solução do problema de Pappus tomado precisamente com a mesma formulação de Descartes na Geometria.

Primeiramente, consideremos o enunciado do Lema XIX:

\begin{abstract}
"Encontrar um ponto $\mathrm{P}$ tal que se quatro linhas PQ, PR, PS e PT são traçadas a partir dele em ângulos dados, para quatro outras linhas $A B$, $\mathrm{CD}, \mathrm{AC}$ e $\mathrm{BD}$ dadas em posição, e traçadas a partir do ponto $\mathrm{P}$, até encontrar as quatro outras linhas, o retângulo PQ.PR sob duas das linhas traçadas terá uma dada razão para o retângulo PS.PT sob as outras duas." (Newton, 1999, p. 483)
\end{abstract}

Vale destacar que a escolha da letra

$\mathrm{P}$, para designar o ponto que se quer encontrar, não é por acaso. Newton está tratando, aqui, da órbita de um planeta: o ponto P. Logo no enunciado notam-se as semelhanças com a apresentação cartesiana do problema de Pappus. A partir desse ponto $\mathrm{P}$, são traçadas quatro linhas que

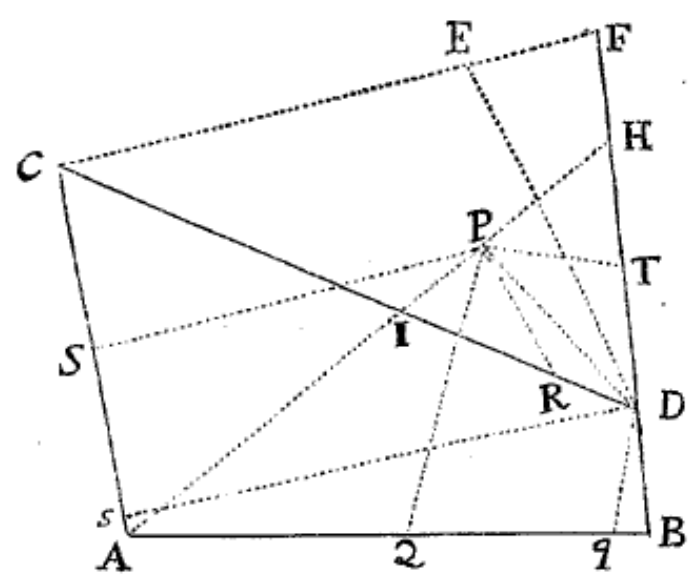

Figura 7 formam, entre si, ângulos conhecidos. Estas encontram outras quatro linhas, formando ângulos que também são dados. São elas $\mathrm{AB}, \mathrm{CD}, \mathrm{AC}$ e $\mathrm{BD}$. O retângulo PQ.PR, ou seja, a multiplicação ou combinação entre as linhas PQ e PR, deve manter uma dada razão para o retângulo PS.PT. Nota-se que cada retângulo está sob duas linhas quaisquer daquelas quatro linhas dadas, cujos extremos são o ponto $\mathrm{P}$ e uma outra linha também dada. Neste caso vemos, na figura, que PS encontra CA, PQ encontra AB, PR encontra CD e PT encontra BD, ou melhor, seu prolongamento. 
As semelhanças com Descartes

restringem-se ao enunciado. Ao invés de, como Descartes, supor o problema como já solucionado e fornecer o meio pelo qual se chega a tal solução, Newton inicia por uma construção geométrica. Considerando os pontos A, B, C e D, supõe-se que neles são dadas em

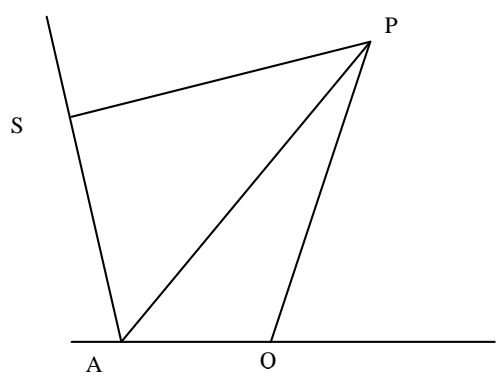

Figura 8 posição as retas $\mathrm{AB}$ e $\mathrm{CD}$ para as quais são traçadas as retas $\mathrm{PQ}$ e $\mathrm{PR}$, que compõem um dos retângulos ou multiplicações. Partindo de um dos pontos, no caso A, é traçada uma linha que passará pelo ponto $\mathrm{P}$ e cortará o prolongamento de $\mathrm{BD}$ em $\mathrm{H}$ e a linha $\mathrm{CD}$ em I. Essa linha funcionará como uma ordenada que dará a posição do ponto P.

Já que as linhas todas são dadas em posição, pode-se afirmar que todos os ângulos são conhecidos. Assim, os pontos A, P e Q formam um triângulo e os pontos A, P e S formam outro triângulo que compartilha com o primeiro o lado AP. Sendo assim, PQ e PA possuem uma certa razão e ela é conhecida, pois são os lados de um mesmo triângulo cujos ângulos são dados. O mesmo ocorre entre PA e PS. Ora, se é conhecida a razão entre PQ e PA e também a razão entre PA e PS, é sabida, consequentemente, a razão entre PQ e PS. O enunciado garante que os retângulos PQ.PR e PS.PT mantêm entre si uma dada razão. Se, como dito acima, é dada a razão entre PQ e PS, então também é dada a razão entre PR e PT. Ou, nas palavras de Newton, “tomando essa razão (entre PQ e PS) como um divisor para a razão dada de PQ.PR para PS.PT, obtemos a razão de PR para PT’. (Newton, 1999, p. 484).

Considerando os pontos IPR e HTP, sabe-se que formam

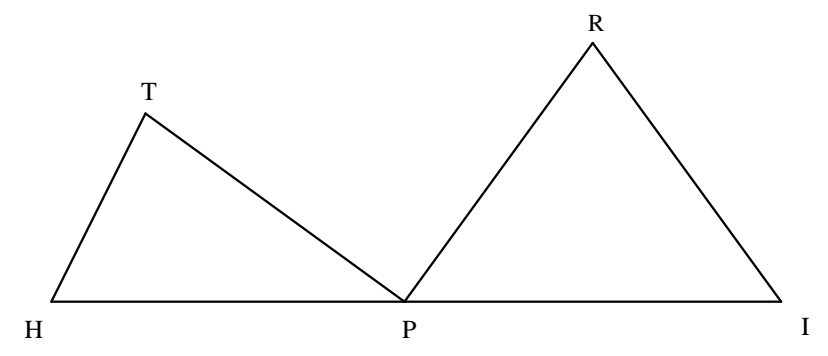


respectivamente dois triângulos cujos ângulos são dados. Então, do mesmo modo que acima, pode-se inferir que PI e PR têm uma razão dada como lados do mesmo triângulo; PT e PH da mesma forma. Se PI é proporcional a PR e PT a PH, então PI é proporcional a PH e essa razão é conhecida, já que todos os ângulos são dados. Como dito no início do desenvolvimento, I, P e H são pontos situados na mesma linha: aquela que serviria de ordenada para se localizar o ponto P. Sendo conhecidas as razões entre as linhas PI e $\mathrm{PH}$, é conhecido o ponto $\mathrm{P}$ que se pretendia encontrar. Com isso se chega à solução que se pedia no enunciado. No entanto, para se resolver o problema de Pappus na formulação dos antigos ou do próprio Descartes, é preciso identificar (ou fornecer um método para isso) o locus, ou seja, o lugar geométrico do ponto $\mathrm{P}$, o que será apresentado nos Corolários.

O Corolário I garante que se pode traçar uma tangente em qualquer um dos pontos do locus onde se localizam todos os pontos $\mathrm{P}$ possíveis. Para isso, Newton utiliza-se o método das primeiras e últimas razões. Toma-se, por exemplo, o ponto D. Quando AH é conduzida para o ponto $\mathrm{D}$, de modo que os pontos $\mathrm{P}$ e $\mathrm{D}$ reúnam-se, a corda PD torna-se uma tangente. O Lema VII serve de fundamento para tal afirmação: “O mesmo sendo suposto (que os dois pontos em questão reúnam-se), afirmo que a razão final do arco, da corda e da tangente, qualquer um para qualquer outro, é a razão última de igualdade".

$\mathrm{Na}$ situação em que os pontos reúnem-se, as linhas evanescentes IP e PH ainda mantêm a mesma razão obtida acima antes de anularem-se completamente. Supondo-se uma linha AD, traça-se uma outra paralela a esta partindo do ponto $\mathrm{C}$ e

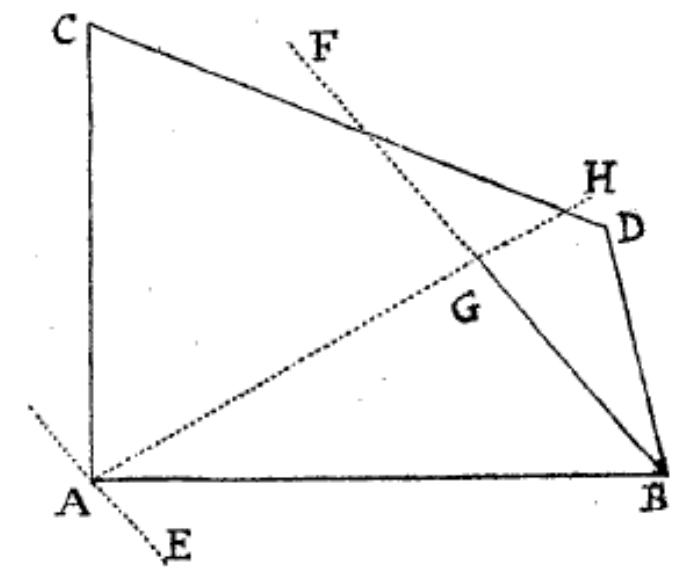

Figura 10 
tocando o prolongamento de $\mathrm{BD}$ em F. Essa linha é cortada em E na mesma razão última entre IP e PH, como se fosse um prolongamento de DP quando as linhas IP e PH são evanescentes. Assim, DE será a tangente, já que a evanescente IH é paralela a CF semelhantemente cortadas em E e P. Pode-se encontrar, então, a tangente em qualquer ponto do lugar geométrico.

Por fim, o Corolário II completa a solução do problema de Pappus, na medida em que permite identificar qual o lugar geométrico de todos os pontos P. A partir daqui, Newton passa a usar apenas a geometria das seções cônicas para expor o modo pelo qual se pode determinar o locus em cada caso. Partindo de qualquer um dos pontos (A, B, C, D), por exemplo A, é traçada a tangente AE. Paralelamente a ela, traça-se BF supondo que F toca o locus. Encontra-se, então, F por este mesmo lema, do modo como foi encontrado P. Bisseccionando BF em G, traça-se a linha $A G$ que será a posição do diâmetro. BG e FG são ordenadas desse diâmetro por determinarem sua posição através da razão que mantém entre si. Fazendo AG tocar o locus em H, encontra-se o diâmetro, ou latus transversus AH. Conhecidos esses dois elementos básicos das cônicas, a tangente e o diâmetro, pode-se determinar o locus através das relações geométricas.

O diâmetro, ou latus transversus, guarda com o latus rectum a mesma razão que há entre AG.GH e $B G^{2}$. Se AG não encontrar o locus, sendo, portanto, infinita, o locus será uma parábola. Nesse caso, seu latus rectum correspondente ao diâmetro AG será $\frac{B G^{2}}{A G}$.

Se AG encontra o locus em algum lugar, ele pode ser uma hipérbole, uma elipse ou um círculo. Será uma hipérbole se o ponto H estiver localizado entre o ponto A e o ponto G. Uma elipse, se o ponto G estiver entre os pontos A e H. Porém, se AGB 
formar um ângulo reto e, simultaneamente, $B G^{2}$ for igual a GA.GH, então o locus será um círculo.

O parágrafo final do texto deixa claro seu propósito:

E, desta maneira, está apresentado neste corolário, não um cálculo analítico, mas uma síntese geométrica, como requerido pelos antigos, daquele clássico problema de quatro linhas, que foi iniciado por Euclides e desenvolvido por Apollonius (Newton, 1999, p. 485).

Descartes submeteu o problema de Pappus a uma habilidosa, como até mesmo Newton reconhece, exploração analítica, introduzindo um par de coordenadas oblíquas ( $x$ e $y$ ) a fim de traduzir em uma equação as condições que definem o locus e tomando um certo ponto como origem da curva. Esse que significou um eficiente recurso matemático do qual Newton serviu-se amplamente em seus primeiros escritos, tornouse, entretanto, alvo de severas críticas que culminaram com uma virada radical do ponto de vista metodológico por parte de Newton, a partir dos anos de 1670. Os principais elementos dessa virada podem fornecer esclarecimentos relevantes no que diz respeito aos fundamentos do pensamento newtoniano tomado em sua maturidade.

Considerando as duas soluções apresentadas para o problema de Pappus, pode-se identificar um núcleo comum e, além dele, as alterações substanciais que ocorreram na transição da análise cartesiana para a síntese newtoniana. Descartes e Newton parecem concordar que a resolução de problemas na geometria comporta duas etapas: uma analítica e outra sintética. Descartes fundamenta na etapa analítica toda a estrutura do seu método, restando à etapa sintética o caráter de simples demonstração complementar. Newton, por sua vez, confere à etapa analítica a característica de uma etapa preliminar de descoberta que deve ser ocultada, a exemplo do que fizeram os antigos; e à etapa sintética, a responsabilidade de, sozinha, apresentar a solução do problema. Essa 
distinção entre eles se torna evidente nos respectivos desenvolvimentos do problema de Pappus. Descartes procede a uma exploração analítica do problema, a fim de reduzir sua complexidade a equações e, só então, passa para uma etapa sintética que tem como finalidade construir a curva-solução do problema, através dos elementos característicos evidenciados nas equações. Newton, por outro lado, despreza a etapa analítica cartesiana, partindo diretamente para a construção. Entretanto, já que ele abriu mão da etapa analítica, não utiliza a equação nesse processo de construção, mas, recorre à identificação de vários pontos que, através da construção geométrica, fornecem a curva procurada. A consolidação dessas diferenças tem a crítica como seu ponto de partida.

Procurei sustentar que o ponto central da crítica de Newton ao simbolismo analítico repousa sobre a falta de um correspondente geométrico para alguns dos elementos utilizados nas equações. Aliado a isso, as grandezas infinitesimais suscitam problemas não apenas dessa ordem, mas também aquelas dificuldades relativas à composição do contínuo. Embora Newton não trate propriamente de critérios ontológicos para os referentes matemáticos, a renúncia aos recursos matemáticos logrados pela análise em virtude da falta de correspondente geométrico dos seus elementos denuncia um radical comprometimento com o realismo matemático. $\mathrm{O}$ modo como Newton contorna o problema da composição do contínuo aponta na mesma direção. A partir da reinterpretação ontológica do modelo cinemático de Barrow, o tempo e o espaço geométricos se revestiram do status do tempo e do espaço eles mesmos, ou seja, absolutos. Isso denota que um forte realismo matemático esteve permanentemente associado à reorientação metodológica da prática matemática de Newton. 


\section{MATEMÁTICA E NATUREZA NOS PRINCIPIA}

O título dos Principia nos indica uma referência explícita a Descartes ao categorizar como "matemáticos" os princípios da filosofia natural. Newton o faz com vistas a distinguir seu projeto da mecânica excessivamente qualitativa de Descartes. Do mesmo modo que a matemática cartesiana, entendida como disciplina, é construída na tentativa de guardar a coerência com o método, o sistema de mundo erguido por Descartes pretende-se fundado nos princípios metafísicos estabelecidos por esse mesmo método. Se existe a exigência de que esse sistema seja matemático, tal exigência se refere à matemática como método e não como disciplina. Assim, a mecânica cartesiana não persegue o objetivo de ser quantitativa, demonstrativa, ou seja, sintética. Ao contrário, ela espelha-se no método da matemática - não no método de demonstração (sintético), mas no de descoberta (analítico) - e deduz dos seus próprios princípios as leis do movimento e todas as demais explicações. Esses princípios, como dissemos acima, são metafísicos e não matemáticos.

Os três livros que constituem os Principia de Newton guardam particularidades que os distinguem entre si, embora se articulem eficientemente em uma obra única. $\mathrm{O}$ Livro I inicia com a exposição do método das primeiras e últimas razões, de que tratamos no capítulo anterior. A seguir, e até o final do Livro II, Newton vai abordar problemas que envolvem termos diretamente relacionados à natureza, como "velocidade", "força" e "atração"; abstraindo-os, no entanto, de seus aspectos qualitativos e tratando-os quantitativamente. Tal tratamento é, obviamente, um tratamento matemático. Esse projeto opõe-se àquele pretendido por Descartes na medida em que Newton não precisa se comprometer com explicações metafísicas de tais termos. Porém, o Livro III não vai se beneficiar de tal isenção. Nele, Newton estabelece 
seu "sistema de mundo" e, portanto, se depara com a necessidade de explicar fisicamente (qualitativamente) os termos envolvidos.

Por essa razão, porque o que nos interessa é a prática matemática de Newton, esse capítulo ficará restrito a exemplos dos dois primeiros livros dos Principia. Em particular, trataremos dos problemas que envolvem a determinação da força centrípeta exercida sobre um corpo que descreve uma curva, a partir do centro dessa curva (Livro I). Em seguida, abordaremos os problemas que dizem respeito à determinação do movimento de um projétil em meio resistente (Livro II).

\subsection{O Livro I: determinação de forças centrípetas}

A seção II do Livro I trata da determinação de forças centrípetas, considerando corpos que giram, descrevendo curvas que estão no mesmo plano de seus respectivos centros de força (imóveis). Newton começa tratando de curvas em geral, em seguida considera o movimento em circunferências para, finalmente, tratar da elipse. A seção III, desta forma, começa situando o centro de força em um dos focos da elipse descrita pelo movimento do corpo. Nesse ponto, então, Newton tem seus fundamentos matemáticos assentados para dedicar-se à questão das órbitas dos planetas.

A Proposição I, Teorema I, afirma que as áreas percorridas pelos raios (que ligam o corpo ao seu centro de força) são proporcionais aos tempos nos quais elas são descritas. Nas proposições seguintes, Newton trata da força centrípeta, em geral, sem considerar, ainda, a gravidade. É estabelecida, inclusive, a relação entre a força centrípeta e o quadrado da distância a partir do centro ${ }^{29}$. Entretanto, trataremos não dos

\footnotetext{
${ }^{29}$ Essa relação já havia sido enunciada por Halley e Hooke, anteriormente, no que diz respeito às órbitas dos planetas. Porém, antes de tratar das órbitas elípticas, Newton estabelece uma relação mais geral, aplicável às demais cônicas.
} 
teoremas, mas dos problemas que se encontram a partir da Proposição V, visto que estes evidenciam melhor as opções matemáticas do autor.

O Problema I (Proposição V) é enunciado do seguinte modo:

Tendo sido dada, em qualquer lugar, a velocidade com a qual um corpo descreve uma dada curva, quando está sob a ação de forças que tendem a algum centro comum, pedese que seja encontrado esse centro. (Newton, 1999, p. 453).

A solução se desenvolve através de dois elementos principais: a associação de certos segmentos geométricos às velocidades e a construção geométrica a partir dos dados. Primeiramente, embora a solução seja aplicável a todas as cônicas, pois o problema supõe uma curva qualquer, Newton constrói essa solução utilizando-se de uma elipse, como exemplo. Tomando-se três pontos da curva $(P, Q$ e $R)$, são traçadas três linhas retas (tangentes) que tocam a figura nesses pontos: PT, TQV e VR, que se encontram em $T$ e $V$. Em seguida, $P A, Q B$ e $R C$ são traçadas perpendicularmente às tangentes e inversamente proporcionais às velocidades nos respectivos pontos. Dessa forma:

$P A: Q B::$ velocidade em $Q:$ velocidade em $P$,

Igualmente,

QB: RC:: velocidade em $R:$ velocidade em $Q$.

Partindo das extremidades $A, B$ e $C$ das perpendiculares, devem ser traçadas $A D, D B E$ e $E C$, em ângulos retos, encontrando-se em $D$ e $E$. Tendo definido esses dois pontos, traçam-se duas retas (TD e $V E$ ) que se encontrarão no ponto $S$. Justamente esse ponto será o centro requerido. 
Como vemos, trata-se de uma solução estritamente conduzida pela construção geométrica. O que a separa da geometria dos antigos é apenas, e tão somente, a proporção que se estabelece entre os segmentos e as velocidades do corpo nos pontos em questão. Entretanto, afirmar que Newton realizou um "retorno à geometria dos antigos" não significa supor que esse será o padrão de solução presente ao longo de toda a obra. A própria extrapolação da geometria para os casos de movimentos nascentes e evanescentes, exemplificada no capítulo anterior, mostra que esse suposto retorno amplia o alcance do método, ainda que prescindindo dos recursos alcançados na etapa analítica. Assim, embora o que se chama de "retorno" não seja sinônimo de retrocesso, houve uma mudança significativa de abordagem que se evidencia pelas opções matemáticas de Newton. Com a finalidade de explicitar essa nova abordagem, consideremos os problemas que se seguem.

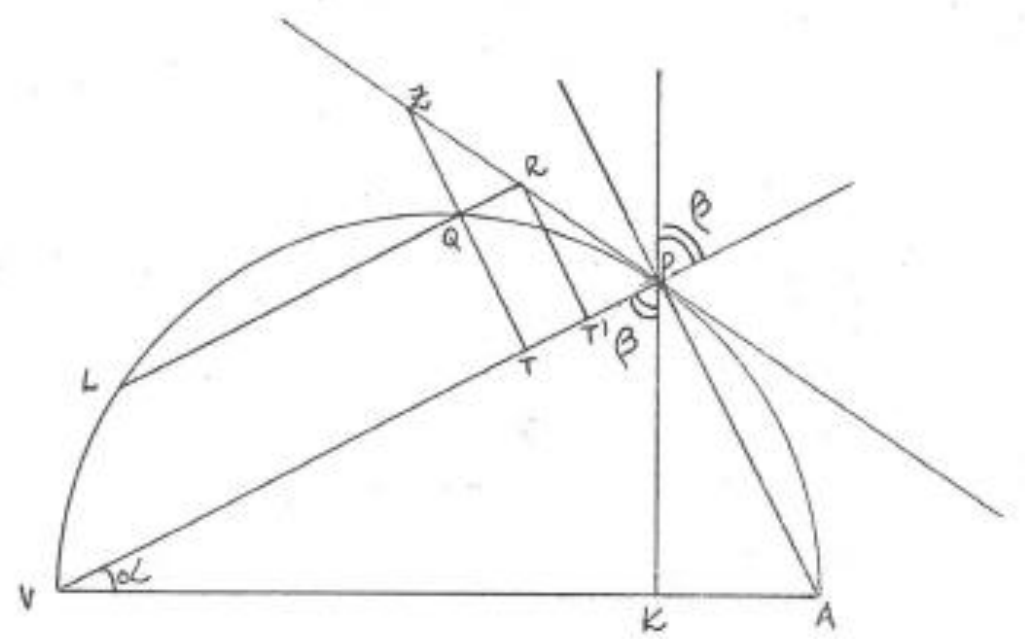

Figura 11 - Proposição VII, Problema II 
O Problema II (Proposição VII) é o problema de encontrar a força centrípeta dirigida para um ponto qualquer, quando o corpo gira na circunferência de um círculo. Newton inicia assumindo que os triângulos $Z Q R, Z T P$ e $V P A$ são semelhantes. A fim de tornar mais evidente o desenvolvimento, chamaremos de $\alpha$ os ângulos agudos desses triângulos. Traçando uma reta paralela ao segmento $Q T$ e partindo de $R$, marcamos o ponto $T$ ' no segmento $T P$.

Teremos, então, um novo triângulo $R P T$ ', semelhante aos demais, cuja hipotenusa é $R P$, o cateto oposto a $\alpha$ é $P T^{\prime}$ e o cateto adjacente a $\alpha$ é $R T$ '. Vale notar que $R T^{\prime}=Q T$. É estabelecida uma relação de proporcionalidade entre os triângulos $R P T$ ' e VPA, levando-se em conta suas hipotenusas e catetos:

$$
R P^{2}: Q T^{2}\left(=R T^{\prime 2}\right):: A V^{2}: P V^{2}
$$

Da mesma forma, outra relação de proporção é estabelecida, resultando em:

$$
R P^{2}=R L \times Q R
$$

A fim de refazer a proporcionalidade que resultou em (2), supomos que o produto dos meios foi igualado ao produto dos extremos, e que RP figurava em ambos os lados da igualdade já que a operação resulta em $R P^{2}$. Assim, teríamos:

$$
R L: R P:: R P: Q R
$$

Ou, o que leva ao mesmo resultado,

$$
\operatorname{sen} \alpha^{\prime}=\operatorname{sen} \alpha^{\prime \prime}
$$




\section{CO'/HIP' = CO'/HIP” \\ $R L / R P=R P / Q R \quad(2 \mathrm{~b})$}

Porém, quais os triângulos considerados em $2 \mathrm{a}$ e $2 \mathrm{~b}$ ?

Projetando-se o segmento $L R$ em $P V$ (partindo de $\mathrm{P}$ ), obtemos $P L{ }^{\prime}=R L$ e o triângulo $P R L^{\prime}$, cuja hipotenusa é $L^{\prime} P(=R L)$ e o cateto oposto (sempre ao ângulo $\alpha$ ) é $R P$. O segundo triângulo é $R P T^{\prime}$. Podemos ver que $R Q=P T^{\prime}$ traçando-se uma corda que passe por $Q$ e $T^{\prime}$ e que seja paralela à tangente no ponto $P$. Se $R P$ é paralela a $P T^{\prime}$, então,

$$
P T^{\prime}=R Q
$$

Assim, considerando o triângulo $R P T^{\prime}$, seu cateto oposto é $P T^{\prime}(=R Q)$ e sua hipotenusa é $R P$. Se $P R L$ ' e $R P T^{\prime}$ 'são semelhantes, os seus ângulos $\alpha$ são iguais:

$$
\begin{gathered}
\alpha^{\prime}=\alpha ” \\
\operatorname{sen} \alpha^{\prime}=\operatorname{sen} \alpha^{\prime} \\
C O^{\prime} / H I P^{\prime}=C O^{\prime} / H I P^{\prime} \\
R P / R L=P Q / P R \\
R P^{2}=R L . R Q
\end{gathered}
$$

O valor de $R P^{2}$, encontrado em (2), pode ser substituído em (1), gerando:

$$
\begin{gathered}
R L \times Q R: Q T^{2}=A V^{2}: P V^{2} \\
Q T^{2} \times A V^{2}=R L \times Q R \times P V^{2} \\
\boldsymbol{Q} \boldsymbol{T}^{\mathbf{2}}=\boldsymbol{R} \boldsymbol{L} \times \boldsymbol{Q R} \times \boldsymbol{P} \boldsymbol{V}^{2} / \boldsymbol{A} \boldsymbol{V}^{\mathbf{2}}
\end{gathered}
$$

Quando $P$ e $Q$ coincidem, $P V=R L$. Substituindo $R L$ por $P V$ :

$$
Q T^{2}=P V \times Q R \times P V^{2} / A V^{2}
$$


Multiplicando ambos os lados por $S P^{2} / Q R$ :

$$
\begin{gathered}
Q T^{2} \times S P^{2} / Q R=P V \times Q R \times P V^{2} \times S P^{2} / A V^{2} \times Q R \\
\boldsymbol{P} \boldsymbol{V}^{\mathbf{3}} \times \boldsymbol{S \boldsymbol { P } ^ { 2 }} / \boldsymbol{A} \boldsymbol{V}^{\mathbf{2}}=\boldsymbol{Q} \boldsymbol{T}^{\mathbf{2}} \times \boldsymbol{S \boldsymbol { P } ^ { 2 }} / \boldsymbol{Q R}
\end{gathered}
$$

Pela Proposição VI, Corolários I e V, a força é inversamente como $Q T^{2} \times S P^{2} / Q R$. Então, ela será também inversamente como $P V^{3} \times S P^{2} / A V^{2}$. Porém, como $A V^{2}$ é dado, a força será inversamente como $S P^{2} \times P V^{3}$.

Newton apresenta, ainda, uma segunda maneira de resolver o mesmo problema. Traçando-se SY perpendicular à tangente, obtêm-se os triângulos semelhantes SYP e VPA. Assim,

$$
A V: P V:: S P: S Y
$$

Portanto,

$$
\begin{gathered}
A V \times S Y=P V \times S P \\
\boldsymbol{S} \boldsymbol{S} \boldsymbol{S P} \times \boldsymbol{P V} / \boldsymbol{A V}
\end{gathered}
$$

Elevando todos os membros de (5) ao quadrado e multiplicando os dois lados da igualdade por PV, teremos:

$$
\begin{gathered}
S P^{2} \times P V^{2} \times P V / A V^{2}=S Y^{2} \times P V \\
S P^{2} \times P V^{3} / A V^{2}=S Y^{2} \times P V
\end{gathered}
$$

Pela Proposição VI, a força será inversamente como $S P^{2} \times P V^{3}$, já que AV é dado.

O problema seguinte - Proposição VIII, Problema III - é semelhante ao anterior, diferindo-se apenas por considerar um centro de força remoto, de modo que a linha que une o ponto da posição inicial do corpo ao centro de força pode ser considerada, para 
efeitos de cálculo, paralela à linha que une o ponto da posição final do corpo ao centro de força.

Newton parte da semelhança entre os triângulos retângulos $C P M, P Z T$ e $R Z Q$, cujos ângulos agudos nomearemos por $\alpha$. Então, estabelece a seguinte proporção:

$$
C P^{2}: P M^{2}:: P R^{2}: Q T^{2}
$$

No caso do triângulo $C P M$, está claro que a proporção tomada é entre a hipotenusa e o cateto adjacente a $\alpha$. Entretanto, para mostrar a segunda proporção, é preciso marcar um outro ponto que chamaremos de $T^{\prime}$, encontrando o triângulo $P R T^{\prime}$. Já que $R T^{\prime}$ é igual a $Q T$, então $R P$ (hipotenusa) é proporcional a $R T^{\prime}$ (cateto adjacente), de onde se conclui (6). A igualdade $P R^{2}=Q R(R N+Q N)$ foi retirada de uma proporção semelhante.

Traçando uma corda paralela à tangente e que passa pelo ponto $Q$, ela marcará a linha $P M$ em $T^{\prime}$. Retomando o triângulo $P R T^{\prime}$, podemos afirmar que $P T^{\prime}=R Q$, visto que são retas paralelas (assim como as duas retas que complementariam o paralelogramo $\left.Q R P T^{\prime}\right)$. Portanto, o cateto oposto a $\alpha\left(P T^{\prime}\right)$, no triângulo $P R T^{\prime}$ 'é igual a $Q R$ e proporcional à hipotenusa $P R$.

O segundo triângulo é menos óbvio, mas sabemos que será uma proporção entre a hipotenusa e o cateto oposto, assim como o primeiro. Sabemos, ainda, que o segmento $P R$ será repetido na segunda proporção, já que aparece ao quadrado na igualdade. Por hora, supomos que se no primeiro triângulo $Q R$ é o cateto oposto e $P R$ é a hipotenusa, então, $P R$ deve ser o cateto oposto do segundo triângulo e a hipotenusa permanece desconhecida. A proporção poderia ser assim representada:

$$
\text { QR:PR :: PR: hip. }
$$


Considerando que o raio $C P$ forma com a tangente um ângulo reto no ponto $P$, ao ligarmos os pontos $C$ e $R$, obteremos o triângulo $P C R$, semelhante aos demais. Nesse triângulo, o cateto oposto é igual ao segmento $R F$. Notemos, porém, que $F N=Q N$ e, portanto,

$$
R F=F N+N Q+Q R
$$

ou,

$$
R F=R N+Q N
$$

Completando a proporção, teremos:

$$
Q R: P R:: P R:(R N+Q N)
$$

Multiplicando os meios e igualando ao produto dos extremos, chegamos a:

$$
P R^{2}=Q R(R N+Q N)
$$

Quando os pontos $P$ e $Q$ coincidirem, $R N+Q N$ será igual a $2 P M$, já que desaparecerá o segmento $Q R$. Nesse caso, têm-se:

$$
P R^{2}=Q R \times 2 P M
$$

Substituindo em (6) o valor encontrado para $P R^{2}$ em (8), obteremos:

$$
C P^{2}: P M^{2}:: Q R \times 2 P M: Q T^{2}
$$

o que resulta em:

$$
Q T^{2} / Q R=2 P M^{3} / C P^{2} \quad(9)
$$

Por fim, multiplicando-se os dois lados da igualdade de (9) por $S P^{2}$,

$$
Q T^{2} \times S P^{2} / Q R=2 P M^{3} \times S P^{2} / C P^{2}
$$

Pelos Corolários I e V da Proposição VI, sabemos que a força centrípeta é inversamente como $Q T^{2} \times S P^{2} / Q R$. Portanto, por (10), ela será inversamente como $2 P M^{3} \times S P^{2} / C P^{2}$. Já que SP e CP são, respectivamente, as distâncias entre o centro de força e o corpo e o centro da circunferência e o corpo, ou seja, são valores dados, 
Newton despreza a razão $2 S P^{2} / C P^{2}$. Assim, a força será inversamente como $P M^{3}$, solucionando o problema.

No Escólio a essa Proposição, Newton afirma que essa solução é válida não apenas para a circunferência, mas, igualmente, para a hipérbole, a parábola e a elipse.

\subsection{O Livro II: movimento em meio resistente}

O diálogo de Newton com Descartes, como vimos acima, não se restringe à matemática. O Livro II dos Philosophiae Naturalis Principia Mathematica trata do movimento dos corpos em meios que apresentam resistência. Sendo que toda a mecânica celeste cartesiana, bem como a gravidade terrestre, está baseada na suposição de uma matéria sutil que não ofereceria resistência ao movimento, mas que, no entanto, conduziria os planetas e satélites em suas órbitas, demonstrar que todo meio oferece resistência ao movimento constitui, para Newton, uma tarefa de base. Isso porque, alcançando tal objetivo no Livro II, ele livra-se dos fundamentos da mecânica cartesiana, a fim de estabelecer novos e pretensamente melhor fundamentados do ponto de vista matemático.

Novamente, essa fundamentação matemática está assentada em uma geometria descritiva, inteiramente dependente da teoria das proporções. Conforme adentramos aos desenvolvimentos matemáticos dos Principia, e diante dos propósitos desses desenvolvimentos, surge a questão de saber se as opções matemáticas não estariam guiadas apenas pelo critério de aplicabilidade aos fenômenos da natureza. Em outras palavras, se o objetivo estabelecido é o de tratar das órbitas dos planetas, seria suficiente ater-se às cônicas renunciando, assim, à multiplicidade de curvas e suas respectivas equações alcançadas pela abordagem analítica. No entanto, embora essa renúncia seja 
possível, ela não parece necessária, visto que as mesmas cônicas podem submeter-se adequadamente às equações. É preciso, então, considerar de modo mais detalhado essas opções matemáticas para alcançar os elementos que podem esclarecer essa questão.

Tratemos, primeiramente, da Proposição IV, Problema II, cujo enunciado é o seguinte:

Supondo que a força da gravidade seja uniforme em qualquer meio homogêneo e que tenda perpendicularmente ao plano do horizonte, definir o movimento de um projétil, neste meio, supondo que sofre uma resistência proporcional à sua velocidade. (Newton, 1999, p.636)

O problema tem como dados iniciais o ponto $D$, que é o local de partida do corpo e o segmento $\overline{D P}$, que diz respeito à direção e à intensidade da velocidade inicial. Partindo daí, Newton estabelece a seguinte proporção:

$D A: A C::$ componente vertical da resistência do meio: força da gravidade

Essa componente vertical da resistência do meio deve ser considerada no início da subida, ou seja, no início do movimento. Em seguida, Newton estabelece uma segunda proporção equivalente à primeira:

Retângulo $A D P$ : Retângulo $A C P::$ resistência inicial: força da gravidade

Claramente, vê-se que as representações matemáticas estão associadas a grandezas físicas, o que fica ainda mais evidente a seguir. 


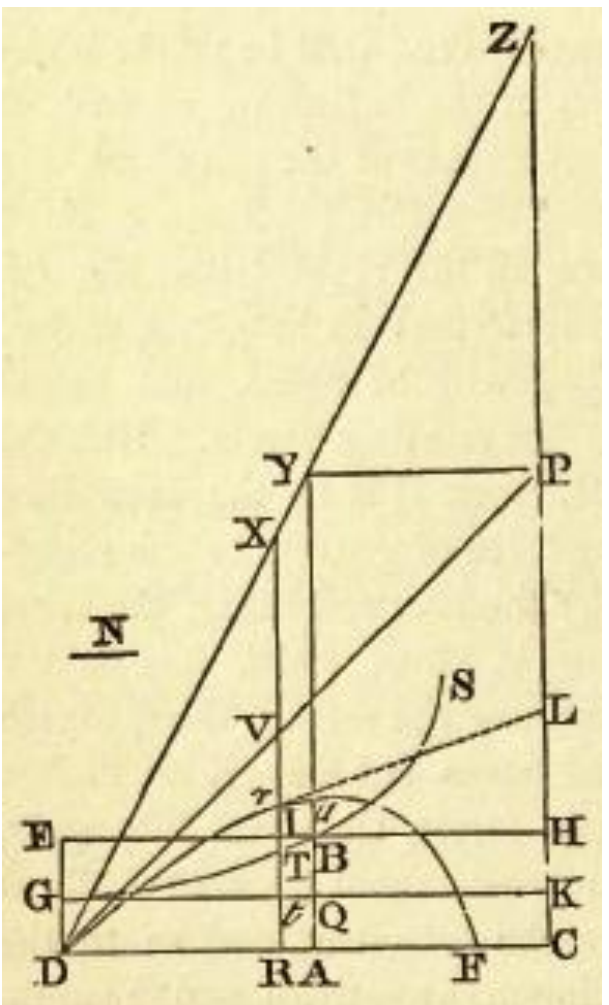

Figura 12 - Proposição IV

A figura 12 é construída como se segue: a hipérbole $G T B S$ de assíntotas $D C$ e $C P$ define os pontos $G$ e $B$ nas ordenadas $D G$ e $A B$. O segmento $A B$, por sua vez é interceptado por $G K$ em $Q$ quando o retângulo $D G K C$ é completado. Externo ao triângulo $C D Z$, o segmento $N$ estabelece a proporção abaixo:

\section{$N: Q B:: D C: C P$}

Como a ordenada $R T$ intercepta a hipérbole em $T$ e as abscissas $E H, G K$, e $D P$ interceptam as ordenadas em $I, t$ e $V$, Newton utiliza uma espécie de "normalização" dos segmentos $V r$ e $R r$ ao considerar que:

$$
V r=\frac{t G T}{N} \quad R r=\frac{G T I E}{N}
$$

Sendo $t G T$ a área curvilínea abaixo da hipérbole, que equivale ao deslocamento do corpo durante a subida, e GTIE a área curvilínea acima da hipérbole. 
Por fim, Newton define o movimento do corpo como a curva DraF, ou seja, o movimento do ponto $r$ de acordo com o tempo DRTG. A altura máxima encontra-se em $a$ situado sobre a ordenada $A B$, e a (intensidade da) velocidade em qualquer ponto $r$ da curva será proporcional à tangente $r L$.

Pois,

$$
N: Q B:: D C: C P:: D R: R V
$$

visto que $\triangle N Q B \approx \triangle D R V \approx \triangle D C P$, porque o segmento $N$ é paralelo a $R V$, que é paralelo a $C P$. Portanto, pela proporção temos:

$$
R V=\frac{D R \cdot Q B}{N}
$$

ou

$$
R r=R V-V r=\frac{D R \cdot Q B}{N}-\frac{t G T}{N}=\frac{D R \cdot Q B-t G T}{N}
$$

O movimento pode ser decomposto em outros dois movimentos: um ascendente e o outro lateral (perpendiculares) aos quais se opõe as respectivas forças resistentes na mesma direção, mas em sentidos opostos a tais movimentos. O movimento lateral está como a linha $D R$ (pelo corolário, proposição 2, Livro II) e a altura (pelo corolário 4, proposição 3, Livro II) como a área $D R \cdot A B-R D G T$, isto é, como a linha $R r$.

Logo,

$$
R r=\frac{D R \cdot A B-R D G T}{N}
$$

Porém, no início do movimento, RDGT é igual ao retângulo formado por $D R . A Q$, portanto, 


$$
R r=\frac{D R \cdot A B-D R \cdot A Q}{N}
$$

Ou seja,

$$
R r: D R:: Q B \text { ou }(A B-A Q): N
$$

e

$$
R r: D R:: Q B: N:: C P: D C
$$

Isso, considerando $C P$ o movimento para cima e $D C$ o movimento ao longo do comprimento.

Como, portanto, $R r$ é sempre como a altura, e $D R$ sempre como o comprimento, e $R r$ está para $D R$ no início como a altura para o comprimento; e, portanto, que o corpo vai mover-se na linha DraF, que é o lugar do ponto $r$. (Newton, 1999, p. 638)

Pelo Corolário III, a parábola de vértice $D$ e de diâmetro $D G$ prolongado para baixo, possui:

latus rectum: 2DP:: resistência inicial: força gravitacional

Nesse ponto, cabe uma explicação do que seja o latus rectum de uma curva. Tomandose uma cônica qualquer, considera-se o foco $O$ estabelecido sobre o eixo. A linha $H X$, perpendicular a esse eixo, é chamada de diretriz e a corda $L L^{\prime}$, que passa pelo foco $O$, e é paralela à diretriz, será o latus rectum. A figura 13 mostra as cônicas e seus respectivos latus rectum.
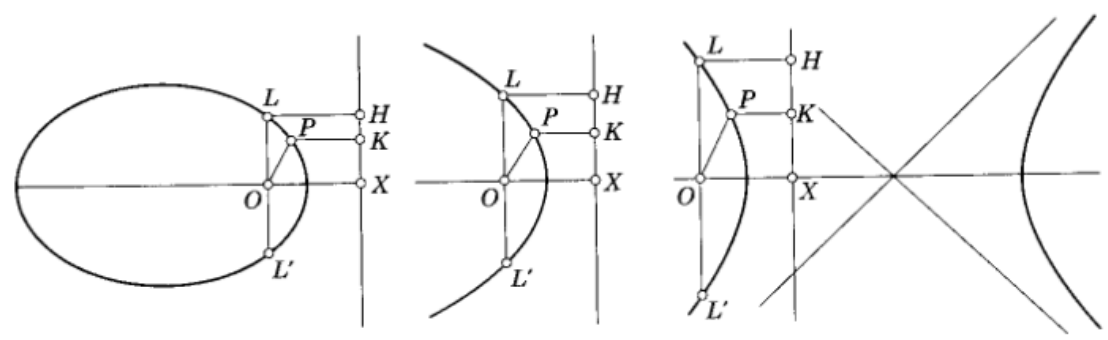

Figura 13 - As cônicas e seus respectivos latus rectum 


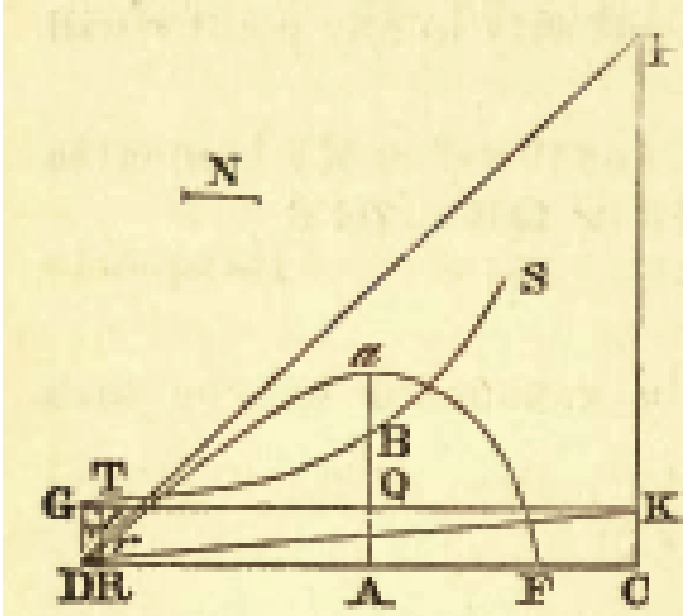

Figura 14 - Corolário III

A velocidade inicial com que o corpo sai de $D$ será a mesma para o movimento em meio resistente e para o movimento num meio que não ofereça resistência. Em ambos os casos, a direção do movimento será na linha $D P$ e a trajetória para o primeiro caso será sob a curva DraF, já noutro caso, a trajetória será parabólica. Dado o latus rectum no início do movimento e $V r$ como

$$
\text { latusrectum }_{o}=\frac{(D V)^{2}}{V r} \quad V r=\frac{t G T}{N}=\frac{D R \cdot T t}{2 N}
$$

Considera-se, em seguida, que a área delimitada pela curva $G T$ é equivalente à metade da área do retângulo $D R t T$, o que conduz à seguinte igualdade:

$$
S_{G t T}=\frac{S_{D R t T}}{2}=\frac{D R \cdot t T}{2} .
$$

Substituindo-se em $V r$, tem-se a expressão anterior. O passo seguinte será o de retirar $N$ da expressão $V r$. 


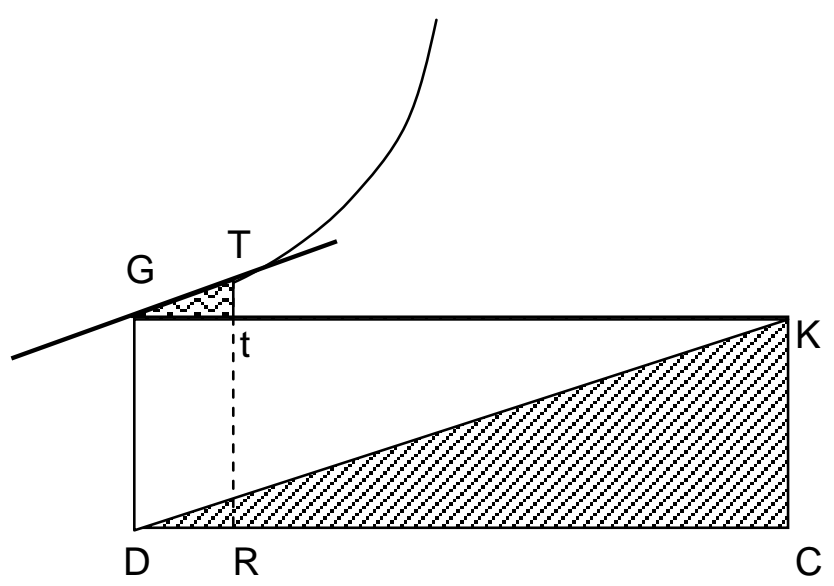

Figura 15 - Semelhança entre GtT e DCK

Tomando com semelhantes os triângulos $G t T$ e $D C K$, tem-se

$$
T t: D R:: C K: D C
$$

Usando a propriedade fundamental das proporções

$$
T t \cdot D C=D R \cdot C K
$$

e isolando $T t$, obtém-se:

$$
T t=\frac{D R \cdot C K}{D C} .
$$

Lembrando que

$$
N: Q B:: D C: C P,
$$

então,

$$
N \cdot C P=Q B \cdot D C .
$$


Isolando $\mathrm{N}$, encontra-se

$$
N=\frac{Q B \cdot D C}{C P}
$$

Considera-se que:

$$
\begin{aligned}
& V r=\frac{D R \cdot T t}{2 N} \\
& V r=\frac{D R \cdot\left(\frac{C K \cdot D R}{D C}\right)}{2\left(\frac{Q B \cdot D C}{C P}\right)}=\frac{D R^{2} \cdot C K}{D C} \cdot \frac{C P}{2 Q B \cdot D C} \therefore V r=\frac{D R^{2} \cdot C K \cdot C P}{2 D C^{2} \cdot Q B}
\end{aligned}
$$

Então, tem-se $V r$ em termos de grandezas conhecidas. Observando a Figura 15, percebese a seguinte proporção:

$D R: D C:: D V: D P$.

Esta proporção também vale para os seus quadrados:

$$
D R^{2}: D C^{2}:: D V^{2}: D P^{2}
$$

Escrevendo em forma de frações:

$$
\frac{D R^{2}}{D C^{2}}=\frac{D V^{2}}{D P^{2}} .
$$


Nesta forma, fica explícita a equivalência que será útil para substituir em $V r$ :

$$
V r=\frac{D R^{2}}{D C^{2}} \cdot \frac{C K \cdot C P}{2 Q B} \therefore V r=\frac{D V^{2}}{D P^{2}} \cdot \frac{C K \cdot C P}{2 Q B}
$$

Como, latus rectum $=\frac{D V^{2}}{V r}$, então

$$
\frac{V r}{D V^{2}}=\frac{C K \cdot C P}{2 D P^{2} Q B} \Rightarrow \frac{D V^{2}}{V r}=\frac{2 D P^{2} \cdot Q B}{C K \cdot C P} \therefore \text { latus rectum }=\frac{2 D P^{2} \cdot Q B}{C K \cdot C P}
$$

Entretanto, QB (componente resistiva), CK (força da gravidade), DA e AC são proporcionais.

(...) corte $D C$ em $A$, de tal forma que $D A$ está para $A C$ assim como a componente vertical da resistência do meio do movimento inicial para cima está para força da gravidade. (Newton, 1999, p. 639)

Portanto,

$$
\begin{gathered}
Q B: C K:: D A: A C \\
\frac{Q B}{C K}=\frac{D A}{A C}
\end{gathered}
$$

Substituindo na expressão que calcula o latus rectum, tem-se:

$$
\text { latus rectum }=\frac{2 D P^{2}}{C P} \cdot \frac{Q B}{C K} \therefore \text { latus rectum }=\frac{2 D P^{2} \cdot D A}{C P \cdot A C} \text {. }
$$

Por fim, 


\section{$(2 D P) \cdot(D P \times D A):(C P \times A C):: R E S I S T E \hat{E N C I A}:$ GRAVIDADE.}

Newton, no início dessa proposição desejava determinar o movimento de um projétil, no meio resistente. A razão entre esta resistência e a gravidade torna-se um parâmetro importante para o entendimento do movimento em questão. Ao final da proposição IV, Newton afirma que a proporção entre a resistência do meio e a velocidade do corpo é uma hipótese matemática. Porque, segundo as leis II e III do movimento, em meios livres de resistência, os corpos resistem uns aos outros como o quadrado das velocidades. Isso porque a resistência é proporcional ao movimento que um corpo comunica ao outro. Ao contrário, em um meio que não é vazio, ou seja, em que o próprio meio apresenta resistência, não é possível que a mesma proporção se mantenha, e, portanto, é preciso determinar a influência que tal resistência exerce sobre o movimento. É a essa tarefa que se dedicam as proposições seguintes.

A Proposição V, Teorema III, estabelece uma proporcionalidade entre as velocidades e os tempos, considerando o movimento de um corpo em um meio homogêneo:

Se um corpo é resistido como o quadrado de sua velocidade, e move-se apenas por sua força inata através de um meio homogêneo, e se os tempos forem tomados em uma progressão geométrica, procedendo dos termos menores pra os maiores, afirmo que as velocidades no início de cada um dos tempos estão inversamente na mesma progressão geométrica; e que os espaços que são percorridos em cada um dos tempos são iguais. (Newton, 1999, p. 642)

Essa proporção é garantida pela condição seguinte: "se o tempo for dividido em inumeráveis intervalos iguais, os quadrados das velocidades no início de cada um dos tempos serão proporcionais às diferenças das mesmas velocidades".

A figura 16 diz respeito à proposição em questão. Sendo $B k \operatorname{lm} G$ a hipérbole e $A B, K k$, $L l, M m$ etc. as perpendiculares, os tempos são representados por: $A K, K L, L M$ etc. 


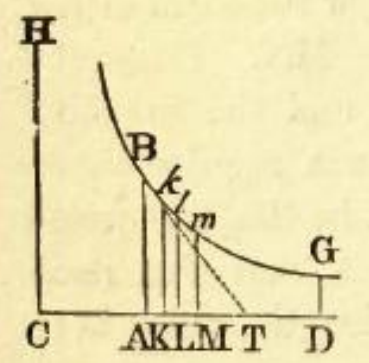

Figura 16 - Proposição V

Então,

$$
A B: K K:: C K: C A
$$

onde a razão inversa entre os seguimentos deve-se à natureza da hipérbole.

Por divisão,

$$
A B-K k: K k:: C K-C A(=A K): C A
$$

invertendo os meios,

$$
A B-K k: A K:: K k: C A
$$

ou ainda,

$$
A B-K k: A K:: A B \times K k: A B \times A C .
$$

São dados $A K$ e $A B \times A C$, então, $A B-K k$ será como $A B \times K k$. Quando $A B$ e $K k$ coincidem, numa variação muito pequena de tempo, logo, será como $A B^{2}$. Por raciocínio similar, tem-se

$$
\begin{aligned}
& K k-L I \propto K k^{2} \\
& L I-M m \propto L I^{2}
\end{aligned}
$$


O quadrado das linhas AB, Kk, Ll, Mm etc. são como suas diferenças, pois, segundo Newton, a progressão de ambos será similar.

Se a linha $A B$ representar a velocidade no início do primeiro tempo $A K$, e a linha $K k$ representar a velocidade no início do segundo tempo $K L$ e a área $A K k B$ o comprimento descrito pelo primeiro tempo, então, todas as linhas seguintes $L l, M m$ etc. representarão todas as velocidades seguintes e as áreas, $K L l k, L M m l$ etc. os comprimentos descritos. Ou seja, para a velocidade $A B$, o tempo do movimento será $A K$ e o comprimento descrito será $A K k B$. Do mesmo modo, para a velocidade $K k$, o tempo será $K L$ e o comprimento $K L l k$. Por fim, para a velocidade $L l$, o tempo será $L M$ e o comprimento $L M m l$. Sendo assim, o tempo correspondente à velocidade total deve ser $A M$ e o comprimento $A M m B$.

Conceba que $A K, K L, L M$ etc. dividem $A M$ de forma que $C A, C K, C L, C M$ etc. estejam em uma progressão geométrica, e que as velocidades $A B, K k, L l$ etc. - pela hipérbole - estejam numa progressão geométrica inversa aos tempos, então, os comprimentos descritos $A K k B, K L l k$, $L M m l$ etc. serão iguais.

Na Proposição VI, Teorema IV, Newton considera a perda de velocidade sofrida pelos corpos, quando há resistência ao movimento. Notadamente, ele está se referindo aos planetas, ao considerar os corpos esféricos. Trata-se, ainda, da referência aos vórtices de Descartes que conduziriam os planetas sem, no entanto, lhes oferecer resistência. O enunciado da proposição é o seguinte:

Corpos esféricos homogêneos e iguais, impedidos por resistências que são como os quadrados das velocidades, e movem-se apenas por suas forças inatas, em tempos que estão inversamente como as velocidades no início, vão perder partes de suas velocidades proporcionais aos todos. (Newton, 1999, p. 644) 


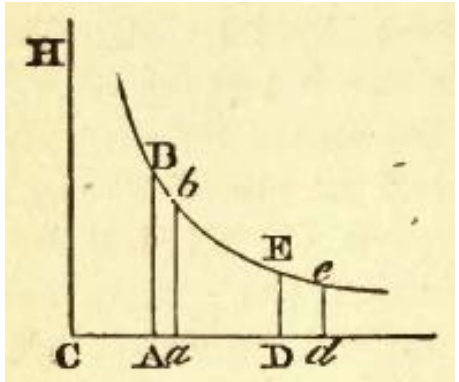

Figura 17 - Proposição VI

Na figura 17, que ilustra a Proposição VI, as velocidades iniciais no inícios dos tempos $A a$ e $D e$ estão representadas pelas perpendiculares $A B$ e $D E$, que tocam a hipérbole $B b E e$. Então,

$$
A a: D d:: \underbrace{D E: A B}_{\text {Hipótese }}:: \overbrace{C A: C D}^{\text {Hipérbole }}:: \underbrace{C a: C d}_{\text {Composição }} .
$$

Pode-se afirmar que as áreas $A B b a$ e $D E e d$, que representam os espaços descritos, são iguais. E as primeiras velocidades $A B$ e $D E$ são proporcionais às últimas velocidades $a b$ e $d e$. Portanto, proporcionais às subtrações, ou partes perdidas das velocidades $A B-a b$ e $D E-d e$.

Na Proposição VII, Teorema V, é estabelecida a proporção entre o espaço percorrido pelos corpos e o produto da velocidade inicial pelo tempo:

Se corpos esféricos são resistidos como os quadrados de suas velocidades, em tempos que são diretamente como os primeiros movimentos, e inversamente como as primeiras resistências, eles perderão partes de seus movimentos proporcionais aos todos, e vão descrever espaços proporcionais ao produto destes tempos e às velocidades iniciais. (Newton, 1999, p.644) 
Sendo assim, as partes dos movimentos perdidos $\left(M_{p}\right)$ são iguais ao produto das resistências $(R)$ e dos tempos $(T)$ :

$$
M_{p}=R \times T .
$$

Pode-se notar a proporção direta entre $M_{p}$ e $T$ e a proporção inversa entre $R$ e $T$, devido esta proporção. Tomados os intervalos de tempo, os corpos sempre perderão partes de seus movimentos proporcionais aos todos. Desta forma, as velocidades sempre serão proporcionais às velocidades iniciais e, por isso, os corpos sempre percorrerão espaços como os produtos entre as primeiras velocidades e o tempo.

Na sequência, a Proposição VIII, Teorema VI, tem o seguinte enunciado:

Se um corpo num meio uniforme sofre a ação uniforme fora da gravidade, subindo ou descendo numa linha reta; e se todo o espaço descrito for dividido em partes iguais, e no começo de cada uma das partes (ao adicionar ou subtrair a força de resistência do meio a favor ou contra a força da gravidade, quando o corpo sobe ou desce) você derivar as força absolutas, afirmo que estas forças estão numa progressão geométrica. (Newton, 1999, p. 650)

Sendo que $A C$ representa a força da gravidade fornecida, $A K$ a força da resistência desconhecida, $K C$ a força absoluta na descida pela diferença, $A P$ a velocidade do corpo (média proporcional entre $A K$ e $A C$, portanto, a raiz quadrada de resistência). A linha curta $K L$ representa o aumento da resistência ocorrido num dado intervalo de tempo, a linha curta $P Q$ é o aumento simultâneo da velocidade e $C$ é o centro. $C A$ e $C H$ são as assíntotas retangulares e $B N S$ a hipérbole. 


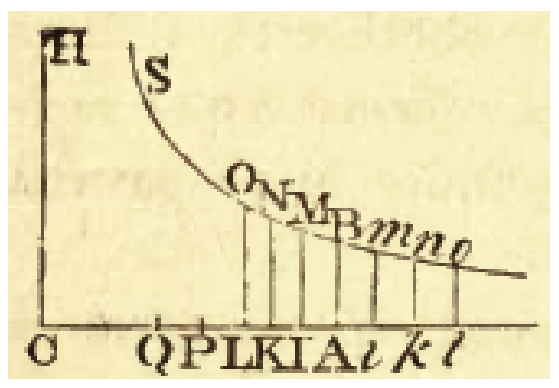

Figura 18 - Proposição VIII

Temos que

$$
\begin{aligned}
& \sqrt{A K}=A P \\
& A K=A P^{2}
\end{aligned}
$$

Quanto aos momentos,

$$
\begin{aligned}
& \text { Momento } K L=\text { Momento } A K \\
& \text { Momento } K L=\text { Momento } A P^{2} \\
& \text { Momento } K L=2 \cdot A P \cdot P Q \\
& \text { Momento } K L=A P \cdot K C
\end{aligned}
$$

Isso porque o incremento $P Q$ da velocidade é (pela Lei II) proporcional à força geradora $K C$. As razões $K L$ e $K N$ são fornecidas, e o retângulo formado pelo produto entre eles se tornará

$$
K L \cdot K N=A P \cdot K C \cdot K N
$$

A última razão da área hiperbólica $K N O L$ torna-se a razão da igualdade de retângulo $K L \cdot K N$, quando os pontos $K$ e $L$ coincidem. Portanto, a área hiperbólica evanescente é proporcional a $A P$. Desta forma, a área hiperbólica total $A B O L$, dividida em intervalos 
$K N O L$, é também proporcional a $A P$, logo, proporcional ao espaço descrito por essa velocidade. Então, as forças absolutas $A C, I C, K C, L C$ etc. estão numa progressão geométrica, assim como, as respectivas áreas hiperbólicas $A B M I, I M N K, K N O L$ etc.

Na subida de um corpo, toma-se o lado direto de $A$, as áreas iguais $A b m i, i m n k$, knol, etc. são continuamente proporcionais às forças absolutas $A C, i C, k C, I C$, etc. Portanto, como os espaços percorridos na subida e na descida são iguais, logo, as forças absolutas $I C, k C, i C, A C, I C, K C, L C$ etc. são continuamente proporcionais.

Finalmente, a Proposição IX, Teorema VII, associa as velocidades às tangentes das curvas e o tempo às próprias curvas descritas pelo movimento:

Supondo o que foi acima demonstrado, afirmo que se as tangentes dos ângulos do setor de um círculo e de uma hipérbole forem proporcionais às velocidades, e o raio sendo de uma grandeza adequada, todo o tempo de subida ao lugar mais alto será como o setor do círculo, e todo o tempo de descida do lugar mais alto como o setor da hipérbole. (Newton, 1999, p.651)

$A C$ expressa a força da gravidade. $A D$ é uma perpendicular de mesmo comprimento que $A C$. Adote $A D$ como semidiâmetro do quadrante $A t E$ de um círculo e da hipérbole retangular $A V Z$, de eixo $A K$, vértice principal $A$ e assíntota $D C$. São traçados $D p$ e $D P$, o setor circular AtD será como todo o tempo de subida para o lugar mais alto e o setor hiperbólico $A T D$ todo o tempo de descida do lugar mais alto, se as tangentes $A p$ e $A P$ forem como as velocidades. 


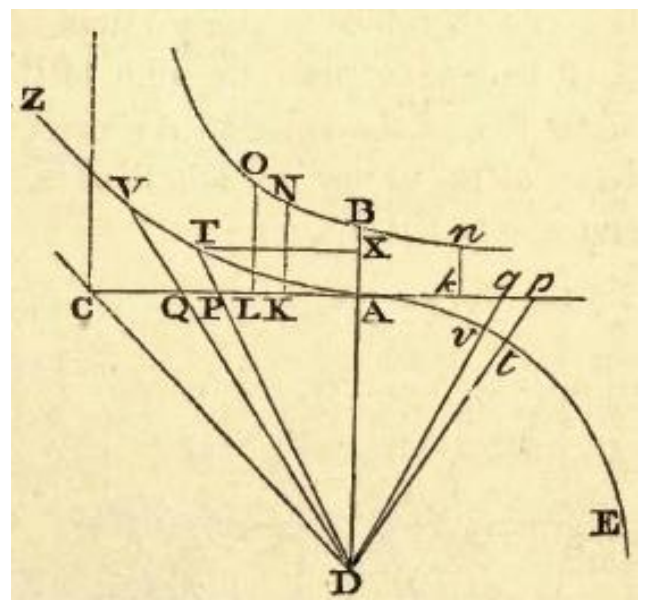

Figura 19 - Proposição IX

No Caso I, dados os momentos ou intervalos mínimos tDv e $q D p$, o primeiro é calculado por $\frac{q D p \cdot t D^{2}}{p D^{2}}$. Se aproximar o arco $v t$ a uma reta, têm-se os triângulos $t D v$ e $q D p$ semelhantes, portanto, a expressão escrita logo acima foi determinada por

$$
q D p: p D^{2}:: t D v: t D^{2}
$$

Como $t D$ é dado,

$$
t D v=\frac{q D p}{p D^{2}}
$$

considere o triângulo $D A p$ e pelo Teorema de Pitágoras, tem-se

$$
p D^{2}=A D^{2}+A p^{2}
$$

Sabe-se que a resistência do meio - força absoluta $A k$ aplicada ao corpo durante a subida - é proporcional ao quadrado da velocidade $A p^{2}$. E a força gravidade $A D$ é 
proporcional a $A k$. Portanto, o quadrado da velocidade é proporcional à resistência e à força da gravidade.

$$
\begin{gathered}
A p^{2} \propto A k \text { e } A k \propto A D \\
A p^{2} \propto A k \cdot A D
\end{gathered}
$$

Logo,

$$
\begin{aligned}
& p D^{2}=A D^{2}+A k \cdot A D \\
& p D^{2}=A D(A D+A k)
\end{aligned}
$$

Mas,

$$
A k=C k-A C \text { e } A C=A D .
$$

Então,

$$
\begin{gathered}
p D^{2}=A D(A D+C k-A D) \\
p D^{2}=A D \cdot C k
\end{gathered}
$$

A área do triângulo $q D p$ é dada por

$$
\frac{1}{2} A D \cdot p q
$$

Então, $t D v$ torna-se

$$
t D v=\frac{q D p}{D p^{2}}
$$




$$
\begin{gathered}
t D v=\frac{\frac{1}{2} A D \cdot p q}{A D \cdot C k} \\
t D v=\frac{A D \cdot p q}{2} \cdot \frac{1}{A D \cdot C k} \\
t D v=\frac{p q}{2 C k}
\end{gathered}
$$

$t D v$ é diretamente proporcional à diminuição da velocidade $p q$ e inversamente proporcional a força absoluta $C k$ a qual diminui a velocidade do corpo durante a subida e, portanto, como o intervalo de tempo correspondente a diminuição da velocidade.

Por composição, a soma de todos os intervalos $t D v$ no setor $A D t$ será como a soma dos intervalos perdidos $p q$ da velocidade decrescente $A p$, até que esta velocidade, sendo reduzida a zero, desapareça: isto é, todo o setor $A D t$ está como todo o tempo de subida ao lugar mais alto. (Newton, 1999, p.653)

No Caso II, traçar $D Q V$ delimitando os intervalos mínimos $T D V$ e $P D Q$ do setor hiperbólico $A D V$ e do triângulo $D A Q$. Assim como no Caso I, define-se a seguinte proporção:

$$
T D V: D T^{2}:: P D Q: D P^{2} \text {. }
$$

Admitindo-se o paralelismo entre $A P$ e $T X$, tem-se

$$
\begin{aligned}
& D X^{2} \propto A D^{2} \\
& T X^{2} \propto A P^{2}
\end{aligned}
$$

Por subtração

$$
D X^{2}-T X^{2} \propto A D^{2}-A P^{2},
$$

mas pela natureza da hipérbole 


$$
D X^{2}-T X^{2}=A D^{2}
$$

ou,

$$
A D^{2}=D X^{2}-T X^{2}
$$

Nessa equação, $A P^{2}$ representa o quadrado da velocidade do corpo durante o movimento de descida. Assim, é proporcional à resistência do meio $A K \mathrm{e}$ à força da gravidade $A D$.

$$
\begin{aligned}
& A P^{2} \propto A K \\
& A P^{2} \propto A D
\end{aligned}
$$

Logo,

$$
A P^{2} \propto A D \cdot A K
$$

Portanto,

$$
T D V: D T^{2}:: P D Q: D P^{2}
$$

Trocando os meios de posição,

$$
T D V: P D Q:: D T^{2}: D P^{2}
$$

Considerando $A P$ paralelo a $X P$,

$$
T D V: P D Q:: D X^{2}: D A^{2}
$$


ou,

$T D V: P D Q:: T X^{2}: A P^{2}$

Por subtração,

\section{$T D V: P D Q:: D X^{2}-T X^{2}: D A^{2}-A P^{2}$}

Desse modo, pela natureza da hipérbole $A D^{2}=D X^{2}-T X^{2}$ e por suposição,

$$
A P^{2}=A D \cdot A K \mathrm{e}
$$

$T D V: P D Q:: A D^{2}: A D^{2}-A D \cdot A K$.

Colocando $A D$ em evidência,

$$
T D V: P D Q:: A D^{2}: A D(A D-A K)
$$

Simplificando $A D$ no segundo membro da proporção,

$T D V: P D Q:: A D: A D-A K$.

Como $A D=A C$,

$T D V: P D Q:: A C: A C-A K$ 
Visto que $C K=A C-A K$,

$T D V: P D Q:: A C: C K$.

Aplicando o princípio fundamental das proporções,

$T D V \cdot C K=P D Q \cdot A C$

Isolando $T D V$,

$$
T D V=\frac{P D Q \cdot A C}{C K}
$$

O triângulo $P D Q$ tem como área $\frac{1}{2} P Q \cdot A D$.

Assim,

$$
T D V=\frac{\frac{1}{2} P Q \cdot A D \cdot A C}{C K}
$$

Como $A D=A C$,

$$
T D V=\frac{\frac{1}{2} P Q \cdot A C^{2}}{C K} \therefore T D V=\frac{P Q \cdot A C^{2}}{2 C K}
$$

Já que $A C$ é dado e o 2 é um escalar, $T D V$ depende somente de $P Q$ e $C K$ :

$$
T D V=\frac{P Q}{C K}
$$


Ou seja, $T D V$ é diretamente proporcional ao aumento da velocidade $P Q$ e inversamente proporcional à força absoluta geradora do movimento $C K$ correspondente ao aumento da velocidade.

Newton conclui afirmando que, considerando a soma de todos os intervalos do setor $A T D$, o tempo total será, por composição, proporcional ao setor total. Ou seja, a soma dos intervalos de tempo em que são gerados todos os intervalos $P Q$ da velocidade $A P$, será proporcional ao setor $A T D^{30}$.

\subsection{De volta à questão do realismo matemático}

A consideração pormenorizada dos passos demonstrativos, utilizados por Newton na solução dos problemas que selecionamos como exemplo, nos permite observar o processo de abstração dos termos originalmente situados no âmbito da natureza. Ao identificar, por exemplo, a velocidade a um segmento, a fim de colocá-la em proporção com outros termos, Newton não está se comprometendo com a descrição qualitativa da velocidade em termos físicos. Mais uma vez, a teoria das proporções desempenha um papel central. Notemos que, no caso dos problemas de determinar a força centrípeta, Newton estabelece como resposta final uma sentença que afirma: "a força centrípeta é inversamente como...”. Ou seja, a força centrípeta estabelece com esse valor - que, na realidade, é uma combinação de segmentos ou outros elementos da curva - uma relação inversa de proporcionalidade. O percurso que conduz a essa relação inclui, necessariamente, a construção da figura que descreve o movimento e seus elementos característicos, como tangente da curva, corda, segmentos paralelos aos primeiros e, frequentemente, a construção de triângulos semelhantes que comportem

\footnotetext{
${ }^{30}$ Os desenvolvimentos matemáticos apresentados nessa seção são fruto dos esforços do grupo de estudos newtonianos da UFPr, com especial destaque para o trabalho de Luiz Felipe S. de Miranda.
} 
tais elementos característicos. A novidade, com relação à geometria dos antigos, é que os segmentos e elementos característicos estão associados a quantidades físicas e, através da relação geométrica que eles mantém entre si, relacionam também essas quantidades físicas.

Diante desse cenário, parece ser possível afirmar que a questão do realismo matemático não desempenha nessa etapa da prática matemática de Newton o mesmo papel que desempenhava com relação ao método das primeiras e últimas razões. Newton não se confronta, aqui, com problemas envolvendo grandezas infinitamente pequenas e composição do contínuo. Mesmo o tempo, cuja importância era capital para garantir o caráter fluente do movimento, é tomado, nessa etapa, em seu caráter discreto. Lembremos que Newton considera, frequentemente, intervalos de tempo que são colocados em relação assim como qualquer outra grandeza.

Portanto, postas à parte as discussões que surgiram em torno do método das primeiras e últimas razões, parece não haver uma relação direta entre a escolha do método sintético e exigências de caráter ontológico, quaisquer que sejam. Por outro lado, de um ponto de vista metodológico, a escolha pelo método sintético parece bastante razoável. Primeiramente, ainda que tratadas matematicamente, as grandezas de que tratam os problemas são grandezas físicas. Trata-se de analisar os casos particulares dos fenômenos a serem demonstrados, o que permite abrir mão da generalidade alcançada pela análise, em proveito de um desenvolvimento fundamentado na construção geométrica que descreve o movimento considerado. Esses problemas, no caso dos exemplos do Livro I, caminham na direção de um objetivo comum, a saber, o de demostrar as leis que regem o movimento dos planetas em suas órbitas. Algumas dessas leis, como a do quadrado das distâncias, já haviam sido enunciadas 
anteriormente. Então, o que está em jogo é a prova, a demonstração dessas leis e, para tanto, recorre-se, naturalmente, à abordagem sintética.

Desse modo, diferentemente das consequências extraídas da apresentação sintética do método das fluxões, a opção pela geometria sintética dos antigos, nessa etapa da prática matemática de Newton, está fundamentada em razões predominantemente metodológicas. Não parece ser possível extrair exigências de ordem metodológica que determinem tal opção. Se elas existem, são devidas a questões mais fundamentais que perpassam a obra como um todo.

É fundamental esclarecer que a exigência ontológica de que tratamos diz respeito aos objetos matemáticos e não à correspondência desses objetos com as grandezas da natureza. A característica, enunciada anteriormente, de que os primeiros livros dos Principia utilizam termos associados a grandezas físicas, mas de maneira abstrata, matemática, não se aplica ao Livro III. Nele, Newton se confronta com a ontologia dos objetos verdadeiramente como grandezas físicas, pertencentes à natureza e não apenas abstraídas em suas relações matemáticas. Por essa razão, o Livro III foge do escopo dessa pesquisa, justamente por extrapolar a questão do realismo matemático ${ }^{31}$

\footnotetext{
${ }^{31}$ Para uma abordagem dessa questão, cf. Barra, 2010.
} 


\section{Conclusão}

Considerando que o paralelo entre a análise e a síntese ocupa um estatuto central, na discussão a respeito do realismo matemático, foi necessário dedicar uma parte significativa da pesquisa à delimitação do modo como esses dois âmbitos se desenvolvem no interior da obra newtoniana. Embora tenha encontrado mais partidários entre os comentadores, a tese de que houve uma ruptura radical entre a etapa analítica e a sintética, como vimos, não é uma unanimidade. Marco Panza ${ }^{32}$ sustenta que essa tese da ruptura articula a relação entre a análise e a geometria de modo completamente equivocado. Segundo ele, essa relação não pode ser reduzida a uma oposição entre duas orientações distintas, dois modos de fazer matemática, dois modos de formular e resolver problemas, ou ainda, a um enfrentamento entre duas linguagens. A única distinção radical possível entre a análise e a geometria seria a caracterização de ambas como teorias matemáticas distintas e que, portanto, se referem a dois domínios distintos de objetos. Por essa razão, Panza, assume que a análise cartesiana se caracteriza como um novo modo de se fazer geometria. Entretanto, já que ela contempla objetos legitimamente geométricos, não se pode negar que ela esteja restrita à geometria. Desse modo, no que diz respeito à matemática newtoniana, não haveria sentido em se referir a um "retorno à geometria", pois as investigações de caráter analítico que levaram Newton à redação do De Methodis são investigações a respeito da geometria e seus resultados são geométricos. Desses mesmos resultados, podem-se extrair o núcleo argumentativo e os procedimentos matemáticos dos quais vai emergir a geometria diferencial dos Principia. Desse modo, pode-se dizer que Panza advoga a tese de que há

\footnotetext{
${ }^{32}$ Cf. Panza (2001) p. 8.
} 
uma continuidade na obra newtoniana garantida pelo caráter geométrico dos objetos, dos problemas e das resoluções em questão.

Ao assumir essa tese da continuidade, no entanto, é necessário reavaliar as bases sobre as quais se apresenta a questão do realismo matemático. Enquanto que a tese da ruptura conduz quase que diretamente ao comprometimento de Newton com o realismo (após a ruptura), a suposição de que os métodos cartesianos guardam intacto seu caráter geométrico introduz um novo elemento consideravelmente mais complexo. A álgebra geométrica introduzida por Descartes na Geometria consiste em certos procedimentos argumentativos capazes de associar a uma ampla classe de curvas equações algébricas que as definem. Tais procedimentos são estendidos e enriquecidos por Newton alcançando algoritmos mais gerais. Então, o De Methodis marca uma etapa embrionária do que será mais tarde, segundo Panza, a análise ${ }^{33}$, no sentido euleriano. Esta sim deve ser entendida como uma teoria matemática cujo domínio de objetos é distinto e que resulta de um processo que tem apenas sua origem na teoria das fluxões. Dito de outro modo, os primeiros estudos matemáticos de Newton, chamados de analíticos, ainda não constituem uma nova teoria distinta da geometria, mas tão somente seus primeiros passos.

Esse novo cenário impõe a tarefa de explicitar de que maneira a questão do realismo matemático pode ser posta diante da tese da continuidade, e, ainda, se ela pode ser posta diante dessa tese. Assumindo a preservação do caráter geométrico dos objetos na teoria das primeiras e últimas razões, como seria possível afirmar que a posterior opção pelo método sintético é devida a uma exigência, supostamente não cumprida pela análise, de um caráter geometricamente representativo dos símbolos das equações? Ou,

\footnotetext{
${ }^{33}$ Panza especifica o termo análise, para diferenciar de qualquer sentido mais geral, como uma teoria levada a termo por Euler que contempla novos objetos matemáticos definidos mediante novos critérios de identidade. A esse novo domínio de objetos se referem novos problemas cuja solução depende de novos critérios de validade. Essa teoria foi capaz de estabelecer um terreno de unificação para toda a matemática, reduzindo a geometria a uma possível aplicação.
} 
reformulando o problema, como caracterizar o abandono por Newton desse algoritmo desenvolvido a partir dos métodos cartesianos? Panza sustenta que esses métodos cartesianos foram estendidos por Newton e combinados com os métodos de quadratura a ponto de sugerir a possibilidade de uma teoria autônoma complementar à geometria e não alternativa a ela, o que o permitiu chegar à teoria das primeiras e últimas razões. Os Principia seriam, então, não um abandono de todo o êxito alcançado pela etapa analítica, mas uma apresentação sintética cujo núcleo argumentativo preserva uma continuidade com relação à etapa inicial. No entanto, retorna aqui uma questão central: o que significa essa renúncia à apresentação analítica? Como compreender, a partir dessa perspectiva, a substituição da teoria das fluxões do De Methodis pela sua apresentação sintética nos Principia? Deixa de ser evidente que a razão para a passagem de uma etapa a outra sejam as exigências de ordem ontológica, já que os objetos dos primeiros resultados de Newton não deixam de ser geométricos. No entanto, é preciso explicitar que razões seriam estas e, consequentemente, se a exigência de um realismo matemático exerce ainda alguma função nessa passagem.

Diante dessas duas abordagens distintas, a da ruptura e a da continuidade, mais do que decidir e tomar partido por uma delas, interessa-nos expor e comparar as diversas articulações possíveis, a fim de extrair os elementos que não se encontram na superfície dos textos de Newton. Nesse sentido, essa pesquisa pretende ter mostrado que, vista em seus detalhes, a matemática newtoniana não pode ser adequadamente separada em dois blocos homogêneos dos quais o primeiro é analítico e o segundo é sintético. Exemplo disso são as soluções geométricas, em sentido estrito, apresentadas no manuscrito de 1666. Além disso, a teoria das proporções exerce um papel unificador, desde a matemática cartesiana e passando por todas as etapas da matemática de Newton. Então, análise e síntese parecem consistir apenas em abordagens diferentes de um 
mesmo método e não haveria sentido em estabelecer diferenças significativas na passagem de uma abordagem para a outra.

Por outro lado, afirmar que a reestruturação do método das fluxões (analítico) em uma versão sintética (chamada de método das primeiras e últimas razões) não representa nenhum interesse especial de pesquisa seria negligenciar um fato extremamente revelador. Pois, embora essa mudança tenha ocorrido no interior de uma mesma teoria e, como dito acima, até mesmo de um mesmo método, do ponto de vista da prática matemática do autor, ela não é em nada evidente.

Com base na análise dos exemplos considerados nessa pesquisa, relativos às diversas etapas da matemática newtoniana, sustentamos que justamente essa mudança para uma apresentação sintética do método das fluxões, e apenas ela, concentra legitimamente os argumentos em favor da tese da ruptura. Ou seja, embora não seja possível considerar um divisor de águas que separe a etapa inicial da etapa madura da matemática de Newton, considerada em sua totalidade, há uma divisão significativa nessa passagem. Significativa, em primeiro lugar, por ser necessária. A substituição dos infinitamente pequenos pela noção de limite, característica da abordagem sintética do método, resolve, como vimos, os problemas como o da composição do contínuo. O ponto central, aqui, reside na razão pela qual ela é necessária, pois, uma matemática formalista ou, ainda mais, instrumental, resolveria tais problemas abstendo-se de tocar a ontologia dos objetos matemáticos e concentrando-se na relação que eles guardam entre eles. Ora, a opção por reestruturar o método analítico, já maduro e eficiente na resolução de problemas, em uma apresentação sintética, evidencia o comprometimento com uma ontologia dos objetos matemáticos. Essa ontologia não é explicitada por Newton no que diz respeito aos critérios e fundamentos, mas o comprometimento evidenciado pela prática matemática não pode ser ignorado. 
O mesmo não acontece ao se considerar a matemática dos Principia, exposta em parte do Livro I e na totalidade do Livro II, que abstrai os termos da física, tomando-os em suas relações. A opção pelo método sintético, nesse caso, não parece ser necessária, como no caso descrito acima. Ao contrário, essa opção é conveniente por considerar construções singulares e, desse modo, ser mais imediatamente aplicável às explicações dos fenômenos da natureza. Entretanto, ela não é necessária, pois, em tese, nada impediria que uma abordagem analítica, mais geral, fosse aplicada aos casos particulares. Ela é conveniente, também, em razão da função demonstrativa que uma abordagem sintética proporciona. Ou seja, trata-se não de descobrir, mas de demonstrar as leis que regem o movimento em uma órbita (Livro I) e a resistência da matéria, mesmo que sutil, ao movimento (Livro II). Portanto, se há algum comprometimento com a ontologia dos objetos matemáticos, nesse caso, ele não é derivado da opção pelo método sintético, mas de elementos mais fundamentais que perpassam a obra como, por exemplo, a concepção de que o espaço geométrico não é distinto do espaço absoluto.

Assim, concluímos que a leitura de que a matemática newtoniana está separada em dois blocos homogêneos não resiste a um estudo mais detalhado da prática matemática de Newton. Por um lado porque, supondo que houvesse uma oposição de fato entre os métodos analítico e sintético, eles não estão exclusivamente situados cada um em seu respectivo bloco. Por outro lado, e ainda mais importante, porque a própria oposição não pode ser estabelecida, ao menos em um sentido tão radical. Isso porque os métodos analítico e sintético não são nada além de duas abordagens fundamentadas nas mesmas bases, notadamente na teoria das proporções. Em ambos os casos, trata-se de geometria, já que os problemas são sempre geométricos, assim como os objetos considerados. Entretanto, concluímos também que, embora não seja uma mudança de teoria, a passagem de uma abordagem analítica do método das fluxões para sua 
abordagem sintética concentra elementos de suma importância para a discussão da ontologia dos objetos matemáticos newtonianos. 


\section{Referências Bibliográficas}

APOLÔNIO DE PERGA. Conics. Tradução W. H. Donahue. Santa Fe: Green Lion, 1998.

ARTHUR, R. T. W. Newton's fluxions and equably flowing time. Studies in History and Philosophy of Science. v. 26, n. 2, 340-356, 1995.

BARRA, E. S. O. A primazia das relações sobre as essências: as forças como entidades matemáticas nos Principia de Newton. Scientiae studia: revista latino-americana de filosofia e história da ciência. São Paulo, SP. v. 8, n. 4, 547-569, 2010.

BATTISTI, C. A. O método de Análise em Descartes: da resolução de problemas à constituição do sistema do conhecimento. Cascavel: Edunioeste, 2002.

COHEN, I. B. The Newtonian Revolution; with illustration of the transformation of scientific ideas. Cambridge: Cambridge University Press, 1980.

COHEN, I. B. Introduction to Newton's Principia. In: NEWTON, I. The Principia: Mathematical Principles of Natural Philosophy. Tradução I. B. Cohen e A. Whitman. Berkeley: University of California Press, 1999 [1687].

DESCARTES, R. The Geometry of René Descartes. Tradução D. Smith e M. Lathan, M. New York: Dover Publications. 1954 [1637].

DESCARTES, R. Regras para a Orientação do Espírito. Tradução Maria E. Galvão. São Paulo: Martins Fontes, 1999[1628].

DESCARTES, R. Princípios da Filosofia. Tradução João Gama. Lisboa: Edições 70. 1985.

EUCLIDES. The thirteen books of Euclid's Elements. Tradução, introdução e notas T. L. Heath. New York: Dover, 1956. 3v. 
GARBER, D. Descartes' Metaphysical Physics. Chicago and London: The University of Chicago Press, 1992.

GUICCIARDINI, N. Reading the Principia: The Debate on Newton's Mathematical Methods for Natural Philosophy from 1687 to 1736. Cambridge: Cambridge University Press, 1999.

GUICCIARDINI, N. Newton and the publication of his mathematical manuscripts. Studies in History and Philosophy of Science, v. 35, n. 3, 1-18, 2004.

LOPARIC, Z. Descartes Heurístico. Campinas: UNICAMP, Instituto de Filosofia e Ciências Humanas, 1997.

MANCOSU, P. Philosophy of Mathematics and Mathematical Practice in the Seventeenth Century. Oxford: Oxford University Press, 1999.

MARION, Jean-Luc. Sobre a Ontologia Cinzenta de Descartes. Tradução Armando Pereira de Silva e Teresa Cardoso. Lisboa: Instituto Piaget, 1975.

NEWTON, I. Sir Isaac Newton's Mathematical Principles of Natural Philosophy and his System of the World. Trandução, revisão e notas Florian Cajori. Berkeley : University of California Press. 1934 [1687], 2v.

NEWTON, I. Princípios matemáticos; Óptica; $O$ peso e o equilíbrio dos fluídos.Traduções de Carlos Lopes de Matos, Pablo Rubén Mariconda e Luiz João Baraúna. São Paulo: Abril Cultural (Col. Os Pensadores), 1979.

NEWTON, I. The Principia: Mathematical Principles of Natural Philosophy. Tradução, introdução e notas I. B. Cohen e A. Whitman. Berkeley: University of California Press, 1999 [1687].

NEWTON, I. Tratado de método de series y fluxiones. Tradução Iztaccíhuatl Vargas. México: Unam, 2001 [1671]. 
PANZA, M. Introducción. In: NEWTON, I. Tratado de método de series y fluxiones. Tradução Iztaccíhuatl Vargas. México: Unam, 2001 [1671]. 1-56.

PANZA, M. Newton et les origines de l'analyse: 1664-1666. Paris: Albert Blanchard, 2005.

PANZA, M. Newton. Paris: Belles Lettres, 2003.

PANZA, M. Das velocidades às fluxões. Scientiae studia: revista latino-americana de filosofia e história da ciência. São Paulo, SP. v. 8, n. 4, 509-546, 2010.

SLOWIK, E. Cartesian Spacetime: Descartes' Physics and the Relational Theory of Space and Motion. Dordrecht, Boston and London: Kluwer Academic Publishers, 2002.

VINCENT, J. Descarte la Géométrie de 1637. Paris: Presses Universitaires de France, 1996.

VUILlEMIN, J. Mathématiques et Métaphysique chez Descartes. Paris: Presses Universitaires de France, 1987.

WESTFALL, R. S. Never at Rest; a Biography of Isaac Newton. Cambridge: Cambridge University Press, 1980.

WHITESIDE, D. T. (Ed.) The Mathematical Works of Isaac Newton. New York/London: Johnson Reprint Corporation, 1964, 2v.

WHITESIDE, D. T. (Ed.) The Mathematical Papers of Isaac Newton. Cambridge: Cambridge University Press, 1967-1980, 8v. 